\author{
Hubert Kuberski
}

Warszawa

\title{
Rosyjscy emigranci i polskie podziemie w latach 1939-1948
}

Zarys treści: Udział emigrantów rosyjskich w II wojnie światowej jest znany, choć najczęściej kojarzony ze współpracą i zaangażowaniem po stronie państw Osi. Jednak wśród porewolucyjnej diaspory rosyjskiej w Polsce znaleźli się ludzie, którzy zdecydowali się walczyć w szeregach polskiego podziemia w ramach Wielkiej Koalicji, przeciwstawiającej się Niemcom i ich sojusznikom w latach 1939-1945. Wygnańcy rosyjscy byli zaangażowani w konspirację różnych orientacji - od komunistycznej do narodowej.

Outline of content: The contribution of Russian emigrants to World War II is widely known, but most often it brings to mind their cooperation and involvement at the side of the Axis powers. There were, however, among the post-revolution Russian diaspora in Poland some people, who decided to fight the Germans and their allies within the Polish resistance movement and the Grand Coalition 1939-1945. Russian exiles were involved in conspiracies of various orientations - from communistic to national one.

Słowa kluczowe: II wojna światowa, Polska w czasie II wojny światowej, biała emigracja rosyjska w Polsce, Polskie Państwo Podziemne, konspiracja w Polsce w czasie II wojny światowej, rosyjscy emigranci $\mathrm{w}$ polskim podziemiu

Keywords: World War II, Poland during WWII, White Russian emigration in Poland, resistance movement in Poland during WWII, Russian émigrés in the Polish resistance movement

W 1931 r. w II Rzeczypospolitej mieszkało 138700 osób mówiących po rosyjsku, co stanowiło $0,43 \%$ obywateli Polski; najwięcej w Wilnie (7372 osób, w tym wyznania prawosławnego 5276), tak że było ich tam więcej niż Litwinów. W stolicy Polski przebywało na stałe 4 tys. Rosjan (zaś 9100 osób wyznawało prawosławie), co dawało trzecie miejsce pod względem kryterium pochodzenia, po Polakach i Żydach ${ }^{1}$.

\footnotetext{
1 Województwo wileńskie zamieszkiwało 35981 osób posługujących się językiem rosyjskim, z czego 9625 było wyznawcami prawosławia, Drugi Powszechny Spis Ludności z dn. 9 XII 1931 r., Miasto 
Tak brzmiała opinia anonimowego polskiego analityka rządowego o rosyjskiej kolonii w Wilnie na początku lat dwudziestych: „Składa się ona przeważnie z ludzi przed wojną zabezpieczonych materialnie, a obecnie z powodu [...] stosunków powojennych, zmuszonych się ograniczać do minimum. $\mathrm{Z}$ tego powodu są oni usposobieni do Rządu Polskiego opozycyjnie, a ponieważ najlepsze wspomnienia łączą ich z dawną Rosją - są w większej części monarchistami”"2. Pamiętać należy o stosunku Polaków do „rosyjskości”, „Rosjan” czy „Rosji” - nawet pojmowanych abstrakcyjnie jako „polska rusofobia” - kształtowanym pod ciśnieniem doświadczeń z czasów zaborów, który odrzucali nieliczni obywatele II RP, szczególnie sympatyzujący z komunizmem: „Właśnie w Polsce, bardziej niż gdzie indziej tacy młodzi ludzie jak my, nawet starsi, odrzucali en bloc, z góry, a priori całą wiedzę wielu pokoleń o Rosji. Właśnie dlatego, że to były clichés. Stereotypy tego społeczeństwa, którego się nie rozumiało"3.

Stosunek do samych Rosjan pozostawał ambiwalentny, co znakomicie podsumował Dimitrij Fiłosofow, współpracujący z Polakami ze względów ideowych, a nie finansowych. Ten pisarz rosyjski chyba najlepiej skomentował minusy, a nawet braki polityki narodowościowej i religijnej Polski okresu międzywojennego: „U was w Polsce, są dwa «obozy». Jedni mówią: są Ukraińcy, Białorusini, Rosjan nie ma. Dla Ukraińców i Białorusinów jesteśmy gotowi zrobić wiele. Jednak - nie robi się nic. Drudzy mówią: są tylko Rosjanie. Ale dla Rosjan nic się nie robi. Oba obozy powołują się na siebie, rzekomo ten drugi mu przeszkadza"4. Fiłosofow był najbardziej niezłomnym propagatorem „trzeciej”, antybolszewickiej, antyimperialnej, demokratycznej Rosji. Jego celem była poprawa relacji polsko-rosyjskich oraz przeciwstawianie się symptomom szowinizmu $\mathrm{z}$ obu stron. Zawsze nawoływał o powściąganie konfliktów narodowościowych w II RP, które przynosiły korzyści tylko Związkowi Sowieckiemu.

Większość społeczeństwa polskiego (w tym urzędnicy państwowi i samorządowi) była spętana szablonami, które również były akcentowane przez emigrantów rosyjskich - przy czym należy podkreślić, że w okresie międzywojennym jedynie

Wilno, „Statystyka Polski”, Seria C, z. 48, Warszawa 1937, s. 11; Drugi Powszechny Spis Ludności $z$ dn. 9 XII 1931 r., Województwo Wileńskie bez miasta Wilna, „Statystyka Polski”, Seria C, z. 36, Warszawa 1936, s. 10-11. Województwo nowogródzkie zamieszkiwały 6794 osoby posługujące się językiem rosyjskim, z czego 6489 było wyznawcami prawosławia, Drugi Powszechny Spis Ludności $z$ dn. 9 XII 1931 r., Województwo Nowogródzkie, „Statystyka Polski”, Seria C, z. 71, Warszawa 1938, s. 10-11. Ogółem w Polsce: 138700 (53 300 w miastach), województwo białostockie 35000 (10 $500 \mathrm{w}$ miastach), wileńskie 43300 (9700 w miastach), nowogródzkie 6800 ( $2500 \mathrm{w}$ miastach), poleskie 16200 (7800 w miastach), wołyńskie 23400 (13 $400 \mathrm{w}$ miastach), Mały rocznik statystyczny 1939, Warszawa 1938, s. 22 i 26.

2 Archiwum Akt Nowych (dalej: AAN), Ambasada RP w Paryżu, t. 82, „Zarys rosyjskiego ruchu monarchistycznego na terenie Wileńszczyzny”, k. 129.

3 A. Wat, Mój wiek. Pamiętnik mówiony, t. 1, Warszawa 1990, s. 140.

4 Listy Dymitrija Fiłosofowa do Mariana Zdziechowskiego, red. P. Ławriniec, „Zeszyty Historyczne” 2008, z. 165, s. 185. 
nieliczni emigranci rosyjscy byli gotowi do podjęcia współpracy z Polakami, za co byli poddawani powszechnemu emigracyjnemu ostracyzmowi (Borys Sawinkow czy Dymitr Fiłosofow). Polsko-rosyjskie circulus vitiosus oscylowało między „nieufną nieżyczliwością" i „polską rusofobią" i było „skazane na niepowodzenie”. Z tego też powodu w latach 1918-1939 nie została zainicjowana żadna poważniejsza współpraca wojskowa i wywiadowcza RP z emigrantami rosyjskimi, nie licząc kontaktów z kolejnymi organizacjami Sawinkowa oraz współdziałania z Rosyjskim Związkiem Ogólno-Wojskowym (Русский Обще-Воинский Союз - POBC/ROWS)5.

Komitet Rosyjski (Русский Комитет - RK) we współpracy z Rosyjskim Czerwonym Krzyżem (Русский Красный Крест - RKK) zaspokajał większość potrzeb charytatywnych rosyjskiej emigracji. Zarządzał też Domem Rosyjskim (Русский дом) przy ul. Marszałkowskiej 68, który został zlikwidowany w 1928 r. po nieudanym zamachu Jurija Wojciechowskiego na szefa sowieckiej misji handlowej Aleksieja Lizariewa. Istniały też sawinkowski Rosyjski Komitet Ewakuacyjny (Русский эвакуационный комитет - REK), Rosyjski Komitet Opiekuńczy nad Emigrantami w Polsce (Русский попечительный об эмигрантах в Польше комитет - RPK) oraz wiele innych organizacji społecznych, kulturalnych i charytatywnych ${ }^{6}$.

Centrum życia rosyjskiej diaspory w Polsce pozostawały cerkwie. Ogromna większość emigrantów rosyjskich była związana z cerkwią przez całe dwudziestolecie międzywojenne - czynny udział w życiu duchowym stanowił najważniejszy element „tożsamości rosyjskiej”. Nie jest łatwo ocenić intensywność zaangażowania emigrantów i faktyczną (a nie tylko deklarowaną) liczebność wiernych. Emigranci weszli do istniejących już struktur, usiłując je zmienić w zgodzie ze swoimi poglądami i międzywojennymi potrzebami. Miejsca kultu jednoczyły wszystkich wierzących, ale i tych, którzy wykorzystywali to miejsce do prowadzenia infiltracji „wrogów klasowych”. Przykładowo warszawska cerkiew prawosławna pw. Marii Magdaleny na prawobrzeżnej Pradze była jednym z najważniejszych nieoficjalnych ośrodków zbornych „białych” Rosjan. Ci, po „odśpiewaniu «Boże, Caria chrani» wylegali na plac przed świątynią tworząc istną giełdę. Wielu pojawiało się tam nie tyle z potrzeby ducha, ile dla samych spotkań towarzyskich, wymiany myśli, plotek, załatwiania różnych interesów, nie zawsze zresztą czystych"7.

\footnotetext{
${ }^{5}$ Należy jednak przywoływać w formie anegdoty niepotwierdzone informacje o wizytach składanych incognito przez marszałka Józefa Piłsudskiego swemu towarzyszowi niedoli katorżniczej, duchownemu i emigrantowi rosyjskiemu mieszkającemu w Warszawie, Aleksandrowi Inoziemcowi, zob.: W. Stanisławski, „Myśl polityczna emigracji rosyjskiej w II Rzeczpospolitej: interpretacje przeszłości i koncepcje polityczne”, praca doktorska napisana pod kier. prof. dr hab. S. Rudnickiego, IH UW, Warszawa 2002, mps P. Dr. 358, s. 225-228, 250-258 i 275-286.

6 A. Juzwenko, Polska a „biała” Rosja (od listopada 1918 do kwietnia 1920 r.), Wrocław 1973, s. 108 oraz W. Stanisławski, „Myśl polityczna...”, s. 181-187.

7 A. Jastrzębski, Życie na krawędzi, w: Życie na krawędzi. Wspomnienia żolnierzy antyhitlerowskiego wywiadu, oprac. W. Kozaczuk, Warszawa 1980, s. 90.
} 
Wybuch wojny zmienił całkowicie sytuację, którą tak opisywał Siergiej Wojciechowski:

Upadek Polski był katastrofą dla rosyjskich warszawian. To naruszyło uporządkowane życie, wielu pozbawiło zarobków, a niektórych i schronienia. Obok codziennych trudności niepokojąca była bliskość linii demarkacyjnej, za którą - nad Bugiem - stały wojska sowieckie. W 1939 r. rosyjska ludność Rzeczypospolitej składała się z obywateli polskich i emigrantów bezpaństwowców. Obywatele byli - werbalnie - równouprawnieni z Polakami. Ich przedstawicielem w Sejmie był jedyny rosyjski poseł, wileński staroobrzędowiec, B.A. Pimienow $^{8}$. Emigranci byli posiadaczami paszportów nansenowskich, wymagających częstego przedłużania. Zakup nieruchomości w Polsce był niemożliwy z tym dokumentem. Poruszanie się po kraju było ograniczone do strefy osiedlenia. Wjazd do wschodnich województw został zakazany i dozwolony wyłącznie ze specjalnym pozwoleniem. Pomimo tego, mieszkało się w Warszawie Rosjanom - nawet emigrantom - bezpiecznie. Kraj odetchnął obfitością. Nie było trudno znaleźć pracę, odpowiadającą wiedzy i edukacji. Było wielu mieszkańców związanych z Polską starymi więzi. Wojna uderzył w nich, tak jak również w Polaków9 9

W Warszawie, w chwili jej kapitulacji przed wojskami niemieckimi, istniały trzy emigracyjne organizacje: Rosyjskie Towarzystwo Dobroczynności w Polsce (Русское благотворительное общество в Польше), Rosyjski Komitet Społeczny w Polsce (Российский общественный комитет в Польше) oraz wspomniany Rosyjski Komitet Opiekuńczy nad Emigrantami w Polsce. Po kapitulacji stolicy u niemieckiego komendanta Warszawy (Kommandant der Kommandantur Warschau), Generalleutnanta Conrada von Cochenhausena już 1 października 1939 r. pojawiła się delegacja zorganizowana przez Rosyjski Komitet Społeczny. Wysłannicy z zadowoleniem powitali niemieckiego generała w imieniu całej rosyjskiej ludności Warszawy (w rzeczywistości delegacja nie reprezentowała całej diaspory, a jej działania nie spotkały się z szerokim poparciem). Powstał wówczas Zarząd do Spraw Rosyjskich Emigrantów

\footnotetext{
${ }^{8}$ Parlamentarzystów rosyjskiego pochodzenia w Sejmie i Senacie RP było pięciu: Maciej Kasperowicz (ur. 1869 Wołkowysk, zm. 1939?) pełnił mandat Bloku Mniejszości Narodowych senatora I kadencji z województwa poleskiego; Paweł Korol (ur. 1890 Biała Podlaska, zm. 1939?) w wyborach w 1928 mandat Rosyjskiego Zjednoczenia Narodowego posła II kadencji w okręgu nr 60 (Pińsk); Arseniusz Pimonow (ur. 1863 Biały Dwór, zm. 7.01.1939 Wilno) w listopadzie 1930 $\mathrm{z}$ ramienia BBWR wybrany senatorem III kadencji z okręgu wileńskiego; Borys Pimonow (ur. 1901 Wilno, zm. 1961 Millville) poseł III, IV i V kadencji w latach 1930-1939 z ramienia BBWR w okręgach Święciany i Brasław; Mikołaj Serebrennikow (ur. 1873 Ostrów k. Łomży, zm. 1951 Warszawa) poseł I kadencji Klub Rosyjskiego Zjednoczenia Narodowego, zob.: Polski słownik biograficzny, t. 26, Wrocław 1981, s. 324-326 (Arseniusz Pimonow) i 326-327 (Borys Pimonow) oraz t. 3, Warszawa 1995-1996, s. 299-300 (Mikołaj Serebrennikow); Posłowie i senatorowie Rzeczypospolitej Polskiej 1919-1939. Stownik biograficzny, t. 3: K-Ł, red. P. Majewski, G. Mazur, Warszawa 2005, s. 174-175 (Paweł Korol).

9 С.Л. Войцеховский, Эпизоды, w: Русская эмиграция в борьбе с больщевизмом, ред. С.В. Волков, Москва 2005, s. 401.
} 
(Vertrauensstelle der Russischen Emigranten/Управление делами русских эмигрантов - УДРЭ/UDRE).

W lipcu 1940 r. niemieckie władze okupacyjne wydały dekret w sprawie likwidacji wszystkich rosyjskich organizacji, które istniały w Polsce przed wkroczeniem wojsk niemieckich. Jednocześnie nazwa UDRE została dostosowana do przedwojennego Komitetu Rosyjskiego (Русский комитет - RK). W organizacji było zarejestrowanych około 10 tys. osób - po zajęciu wschodniej Polski przez Armię Czerwoną wielu Rosjan uciekło na zachód i ich liczba w Warszawie znacznie wzrosła. Niemcy utworzyli także komitety ukraiński, białoruski i kaukaski ${ }^{10}$. Sergiej Wojciechowski, brat wspomnianego wyżej Jurija, reprezentował interesy emigracji rosyjskiej w Polsce, tak przed polskimi władzami do 1939 r., jak podczas okupacji Polski przez narodowosocjalistyczne Niemcy. Był pełnomocnym szefem Rosyjskiego Komitetu Społecznego w Warszawie, przekształconego w Russische Vertrauenstelle (Руссише Фертрауенштелле). Komuniści z Polskiej Partii Robotniczej w ogóle nie widzieli różnic pomiędzy organizacjami rosyjskimi i ukraińskimi, czego dowodem jeden z sowieckich dokumentów:

Kierujący PPR robotnicy Pragi, zwłaszcza Kanorzewski [Józef Konarzewski], członek komitetu miejskiego [członek Komitetu Warszawskiego PPR, a później generał brygady MO, komendant główny MO i prezes Głównego Urzędu Ceł] w rozmowie z pracownikiem Wydziału Politycznego t[owarzyszem, kapitanem RKKA] Bagonowskim [Bagnowskim] oświadczył, że do momentu wyzwolenia Pragi w mieście działała UNO [Ukraińska Nacjonalistyczna Organizacja], licząca do 300 ludzi. Obecnie członkowie tej organizacji znajdują się w mieście i kierował nimi pop Panin. Organizacja składała się z dwóch części: jedna część - uzbrojone oddziały, które Niemcy używali do ochrony zakładów, druga [pracownicy] propagandowi. W samej [lewobrzeżnej] Warszawie ta organizacja liczniejsza (do 500 ludzi) i przewodzi jej [Siergiej] Wojciechowski (pracownik Gestapo [sic!]), Markiewicz (adwokat). Organizacja miała broń ${ }^{11}$.

${ }^{10} \mathrm{Na}$ terenach anektowanych przez III Rzeszą oraz w Generalnym Gubernatorstwie rozpoczęło się szybkie tworzenie rosyjskich organizacji oficerskich. Przed wojną rząd Polski zdecydowanie utrudniał działalność takim związkom na terytorium II RP. W kwietniu 1940 r., zgodnie z rozkazem nr 22, Stowarzyszenie Rosyjskich Związków Wojskowych (Объединение русских воинских союзов - ОРВC-ORWS) miało w okupowanej Polsce i ziemiach wcielonych do III Rzeszy: oddział 7 (Danzig [Gdańsk], Warthegau: Posen [Poznań], Litzmannstadt [Łódź], Kalisch [Kalisz] - naczelnik płk D.I. Chodniew) i oddział wschodni (Generalne Gubernatorstwo, naczelnik gen. mjr L.M. Jerogin), zob.: В.И. Голдин, Солдаты на Чужбине Русскиий Обще-Воинский Союз, Россия и Русское Зарубежье В ХХ-ХХІ Веках, (2011), s. 258, http://militera.lib.ru/research/0/ pdf/goldin_vi01.pdf (dostęp: 17.01.2017) і К.К. Семенов, Берлинский узел РОВСа (1920-1945), „Ежегодник Дома русского зарубежья” (2012), s. 37.

11 Центральный архив Министерства обороны Российской Федерации (ЦАМО РФ), ф. 233, оп. 2380 , д. 23 , л. 144, Запись переговоров по прямому проводу члена Военного совета 1-го Белорусского фронта К.Ф. Телегина с заместителем начальника Главного политического управления Красной армии И.В. Шикиным о событиях в г. Варшаве по состоянию на 22.1530 сентября 1944 г. 


\section{Dwaj generałowie}

Na początku wspomnijmy o dwóch wojskowych najwyższych stopniem. Urodzony jeszcze jako poddany cara Aleksandra III, generał brygady rezerwy Stanisław Bułak-Bałachowicz podawał się za Rosjanina, Białorusina i Polaka ${ }^{12}$. Z jego osobą są związani dawni podwładni, oficerowie armii rosyjskiej, którzy walczyli w obronie Warszawy ponownie pod jego komendą. Wcześniej gen. Bułak-Bałachowicz jako oficer rezerwy zgłosił się do służby 3 września 1939 r. do gen. Waleriana Czumy. Sztab gen. Bułak-Bałachowicza znajdował się pierwotnie przy ul. Marszałkowskiej 72, a potem został przeniesiony do budynku przy ul. Litewskiej 3. Zastępcą dowódcy był ppłk Nikołaj Szustrow-Stanisławski, notabene inwalida wojenny (sztab-rotmistrz, naczelnik sztabu ochotniczego oddziału ludowego atamana Bułak-Bałachowicza). We wrześniu 1939 walczyli także inni Rosjanie: kwatermistrz i pułkownik/sztabs-kapitan armii carskiej, Michaił Jakowlew (ataman Zbiorczej Dywizji Kozackiej przy Wojsku Polskim w 1920 r.), „pułkownik” Józef Jurczenko (oficer armii carskiej), rotmistrz Eugeniusz Sztejnike (oficer armii Bułak-Bałachowicza), porucznicy Ado, Werner, Walcew, podporucznicy Nikołaj Kaczanowskij, Ładkowskij i chorążowie Kastorow (inwalida wojenny bez ręki), Łobaczewskij (oficer kozacki dawnej armii Bułak-Bałachowicza). Wybiegając w przyszłość, losy niektórych z nich nie były do pozazdroszczenia. Pułkownik Stanisławski został aresztowany 31 marca 1940 r. i trafił do więzienia. Niemcy rozstrzelali go 21 czerwca 1940 w Palmirach koło Warszawy. A pułkownik/sztabs-kapitan Jakowlew został aresztowany przez Niemców w kwietniu 1940 r. i trafił do obozu koncentracyjnego Auschwitz, gdzie zmarł w lipcu następnego roku. Rotmistrz Sztejnike został aresztowany w 1940 r. i zmarł na Pawiaku ${ }^{13}$.

„Bałachowcy” od 6 września 1939 r. organizowali obronę Wilanowa i Czerniakowa w ramach IV Grupy Operacyjnej Obrony Warszawy lub „Grupy C” (Marek Cabanowski pisze, że "placówka wydzielona” powstała najpierw w Okuniewie, a następnie została przerzucona do Wilanowa). Siły podległe gen. Bułak-Bałachowiczowi składały się z dwóch batalionów piechoty, dwóch szwadronów kawalerii, jednej kompanii podchorążych, jednej baterii artylerii przeciwpancernej,

${ }^{12} \mathrm{~W}$ przypadku generała Stanisława Bułak-Bałachowicza można powiedzieć o „Zatarciu granic”, na co nałożyła się aktywność wojskowa i konspiracyjna w strukturach antybolszewickich, których członkowie podkreślali swoje pochodzenie białoruskie czy może raczej wyraźnie współpracowali ze strukturami rosyjskiej emigracji porewolucyjnej. Przykładowo wzajemnie wykluczające się programy polityczne usiłował też łączyć wileński mitoman „ataman Degacz”, co bynajmniej nie oznacza, że mitomanem był gen. Bułak-Bałachowicz, zob.: W. Stanisławski, „Myśl polityczna...", s. 140.

13 J. Janowski, Dziennik zastępcy dowódcy obrony Warszawy w 1939 roku, w: Obrona Warszawy 1939 we wspomnieniach, red. M. Ciepielewicz, E. Kozłowski, Warszawa 1984, s. 145-146; M. Cabanowski, Generał Stanisław Bułak-Bałachowicz. Ostatni Kmicic II RP i wyklęci żołnierze wojny polsko-sowieckiej 1920 r., Warszawa-Kraków 2013, s. 179-180; А. Кручинный, П. Мицнер, Генерал Станислав Булак-Балахович в 1939 году, „Новая Польша” 121 (2010), nr 7-8, s. 67-74. 
plutonów oficerskiego, rozpoznawczego i żandarmerii oraz czechosłowacko-francuskiego batalionu „legii cudzoziemskiej” - co dawało 1800-2000 żołnierzy i 250 koni (ale tylko 1600 karabinów i 200 szabel). Druga wersja mówi, że gen. Bułak-Bałachowiczowi podlegały tylko wzmocniona kompania piechoty oraz improwizowany stuosobowy szwadron kawalerii, które stanęły na kwaterze w Wilanowie: zabudowaniach folwarcznych, szkole oraz u proboszcza ks. Jana Krawczyka. Oddziały te walczyły w rejonie przedwojennych wsi podwarszawskich - Okuniewa, Wilanowa, Czerniakowa, Służewa, Natolina, Moczydła, a później Marymontu i na Bielanach. Jeszcze przed rozpoczęciem pełnego oblężenia Warszawy, 9 września 1939 r. gen. Bułak-Bałachowicz skierował swojego wysłannika do tworzenia oddziałów ochotniczych w Brześciu Litewskim, Lublinie i Wilnie; tego samego dnia doszło do potyczki pod Otwockiem. Jednocześnie w pozyskanych informacjach z rozpoznania „bałachowców” mogliśmy wyczytać: „e) Od oddziału partyzanckiego gen. Bułak-Bałachowicza z godz. 9.00 na całej przestrzeni od Grodziska po Błonie i Pruszków - nie więcej jak 120 czołgów podzielonych na trzy grupy. Warszawę, nieprzyjaciel ostrzeliwuje ze zdobycznych armat"14.

Już dwa dni później patrol stwierdził obecność na przedpolach Służewa czołgów niemieckich, wysłanych celem rozpoznania. 12 września płk. Romanowskiemu udało się przedrzeć przez okrążenie pod Wołominem - jego grupa walczyła potem aż do bitwy pod Kockiem. Równocześnie żołnierze Bałachowicza odbili Służewiec i tor Wyścigów Konnych za cenę 50 zabitych i rannych. Ponadto „bałachowcy" patrolowali przedpole na południe od Wilanowa. Około południa do 16 września doszło do potyczki w Natolinie kawalerii oddziału generała Bułak-Bałachowicza, wspieranej przez oddział piechoty pod dowództwem porucznika rezerwy Kazimierza Feliksa Wagnera. Niestety Polacy usiłowali szarżować kawalerią na stanowiska niemieckich karabinów maszynowych rozmieszczonych pod Natolinem. Oczywiście było to dowodem wielkiego bohaterstwa, ale też braku rozwagi czy zwykłej ekonomii sztuki wojennej ${ }^{15}$.

Oto jak działania grupy generała widział szef Sztabu Obrony Warszawy: „W kierunku południowo-zachodnim jesteśmy panami rejonu aż po Wilanów i dalej na południe. Wilanów zajmował gen. Bałachowicz z grupą ochotników. Nocny wypad jednej z kompanii 360. pp szlakiem Wilanów-Wolica-Służewiec

14 Obrona Warszawy w 1939 r. Wybór dokumentów wojskowych, oprac. M. Cieplewicz, Warszawa 1968, s. 41 (nr 25: Meldunek sytuacyjny nr 3 dowództwa grupy gen. W. Czumy, 9.09.1939); oraz M. Cabanowski, op. cit., s. 181

15 Polscy historycy wspominają o innym składzie sztabu grupy gen. Bułak-Bałachowicza: szef sztabu mjr pil. dypl. Mieczysław Szczudłowski, oficer do poruczeń por. rez. Eugeniusz Pichell, dowódca oddziału piechoty por. rez. Kazimierz Feliks Wagner, dowódca dywizjonu kawalerii rtm. Stanisław Zagojski, zob.: M. Cabanowski, op. cit., s. 181-182; Warszawa we wrześniu 1939 roku. Obrona i życie codzienne, red. C. Grzelak, Warszawa 2004, s. 512; А. Кручинный, П. Мицнер, ор. cit., s. 67-74 oraz K. Kanabus, Wilanowski Wrzesień 1939 r., www.gazetawilanowska.pl/wilanowski-wrzesien-1939-r/ (dostęp: 17.01.2017). 
natrafił na znajdujący się we wsi Wolica niewielki oddział niemiecki, na ogół jednak na noc Niemcy ściągali swoje wysunięte placówki”16. Dzień później utrzymywała się trudna sytuacja w Wilanowie: „Centrum Wilanowa pod ogniem artylerii nieprzyjaciela, który następnie zaatakował własne [nasze] elementy w Wilanowie (gen. Bałachowicz). Według niesprawdzonych wiadomości, nacierający nieprzyjaciel pędził przed sobą kobiety i dzieci, i pod ich osłoną zbliżał się do naszych placówek"17.

Najskuteczniejszymi działaniami „bałachowców” był nocny wypad z 18 na 19 września pod dowództwem ppłk. Szustrowa-Stanisławskiego. Zdobyczą było $6 \mathrm{ckm}$-ów i 23 skrzynki amunicji. W uznaniu zasług dowodzący został awansowany do stopnia pułkownika i odznaczony Krzyżem Srebrnym Orderu Virtuti Militari kl. V. Później grupa ochotnicza gen. Bułak-Bałachowicza została przerzucona, od 23 września walczyła w północnej części Warszawy, na Marymoncie. Ich ostatnim zadaniem było odbicie 26 września Lasku Bielańskiego i klasztoru Kamedułów na Bielanach. Tego samego dnia dowództwo IV Grupy Operacyjnej objął płk Szustrow-Stanisławski z rozkazu gen. Bułak-Bałachowicza. Ale to starcie zakończyła kapitulacja stolicy. Całkowita liczba strat w grupie gen. Bułak-Bałachowicza obejmowała zabitych 78 oficerów i podoficerów oraz 399 szeregowców $^{18}$.

Po kapitulacji Warszawy, gen. Bułak-Bałachowicz został współtwórcą Konfederacji Wojskowej. Późnym wieczorem 10 maja 1940 r. w kamienicy willowej przy ul. Paryskiej 27 (mowa też o ul. Saskiej 103), w której mieszkał generał, zgromadzili się młodzi ludzie z jego organizacji. Gdy usłyszeli, że pod oknami zatrzymał się samochód policyjny, zaczęli natychmiast uciekać. Bułak-Bałachowicz wyszedł z domu w towarzystwie kilku osób. Podeszli do patrolu niemieckiej Policji Porządkowej (OrPo). Generał nagle zamachnął się laską, na której się wspierał. Zadał dowódcy patrolu potężny cios $\mathrm{w}$ głowę, zabijając go na miejscu. W odpowiedzi został przeszyty serią strzałów. Zamieszanie wśród Niemców trwało kilka sekund, ale dało młodym ludziom czas na tyle, żeby mogli uciec. Nie można stwierdzić, czy gen. Bułak-Bałachowicz poświęcił swoje życie dla ratowania konspiratorów, czy też nienawiść do Niemców eksplodowała wbrew jego woli.

Inna wersja mówi o przynależności gen. Bułak-Bałachowicza do konspiracji o orientacji narodowej - Organizacji Wojskowej Związku Jaszczurczego (OW ZJ), odnoszącego się do tradycji walk między Polakami i Krzyżakami w XV w. Datą rozpoczęcia działalności był 14 listopada 1939 r., gdy doszło do

16 T. Tomaszewski, Byłem szefem Sztabu Obrony Warszawy w 1939 r., w: Obrona Warszawy 1939 we wspomnieniach..., s. 103-104.

17 Obrona Warszawy w 1939 r. Wybór..., s. 227 (nr 173: Meldunek sytuacyjny nr 19 Dowództwa Obrony Warszawy z dnia 17 września do godz. 20.00; 18.09.1939).

18 Oddział używał następujących nazw: Grupa Ochotnicza gen. Bułak-Bałachowicza, Grupa Specjalna, Grupa Operacyjna Południowo-Zachodnia, Grupa Operacyjna III, Grupa Operacyjna IV i Główna Kwatera Partyzantów, zob.: M. Cabanowski, op. cit., s. 185-187 oraz M. Piekarski, Samotna placówka, Warszawa 1989, s. 172. 
spotkania organizacyjnego, decydującego o powołaniu OW ZJ. Uczestniczyli w nim Władysław Marcinkowski, Henryk Suchodolski i Paweł Janczukowicz, a po kilku dniach dołączyli do nich Jan Pożaryski i inż. Wiktor Radziszewski. Wspomnianym aktywistom narodowym udało się skontaktować z kilkoma oficerami WP, znanymi z nieprzyjaznej postawy wobec obozu piłsudczykowskiego i zainteresowanych organizowaniem zrębów podziemia narodowego. Byli wśród nich generałowie Stanisław Bułak-Bałachowicz, Tadeusz Jastrzębski, Józef Plisowski, Mieczysław Poniatowski, Radosław Dzierżykraj-Stokalski oraz pułkownicy Julian Skokowski i Tadeusz Kurcyusz. Niestety nie posiadamy dokładniejszych informacji o działalności gen. Bułak-Bałachowicza ${ }^{19}$.

Współpraca Konfederacji Wojskowej z kręgami ruchu narodowego wpływała negatywnie na jej ocenę przez dowódcę Związku Walki Zbrojnej (ZWZ). Generał Stefan Rowecki ps. „Grot” wspominał w raporcie półrocznym „organizacje nie współpracujące z S. S. S.” (Stowarzyszenie Samoobrony/Samopomocy Społecznej - kryptonim ZWZ):

Konfederacje Wojskowe (pieczątka z godłem państwowym i napisem „Narodowa Armia Ochotnicza - gen. dyw. Stanisław Bułak-Bałachowicz” [sic! - generał brygady rezerwy - H.K.]) - niewielka grupa, złożona z b[yłych] oficerów gen. Bałachowicza. Członkami są funkcjonariusze Gestapo, trochę Polaków i trochę Rosjan białogwardzistów. Gen. B [ałachowicz] został zastrzelony przez Niemców na ul. Francuskiej [Paryskiej] przed swym mieszkaniem w niezbadanych bliżej okolicznościach. Poprzednio głośni i ruchliwi, obecnie nie przejawiają żywszej działalności. Współpraca z nimi w warunkach konspiracyjnych wykluczona. Jeśli potrafią wytworzyć coś wartościowego, wykorzystam w powstaniu ${ }^{20}$.

Sama Konfederacja Wojskowa miała przetrwać do maja 1941 r., ale mieli w niej służyć wyłącznie Polacy. Następnie konspiratorzy z organizacji Bułak-Bałachowicza weszli do struktur ZJ/NSZ oraz ZWZ/AK, jak na przykład ppor. Witold Wincenty Przyborowski ps. „Kulesza”, który został dowódcą plutonu saperów w batalionie AK „Miotła”21.

Drugim oficerem rosyjskim, który przed końcem II wojny światowej dosłużył się stopnia generała majora był Boris Smysłowski (vel Artur Holmston vel von Regenau). Większości osób kojarzy się on z noszeniem munduru Wehrmachtu i współpracą z Niemcami. Po rozpoczęciu wojny domowej walczył jako oficer

19 K. Komorowski, Polityka i walka. Konspiracja zbrojna ruchu narodowego 1939-1945, Warszawa 2000, s. 256 i W.J. Muszyński, Duch młodych. Organizacja Polska i Obóz Narodowo-Radykalny w latach 1934-1944. Od studenckiej rewolty do konspiracji niepodległościowej, Warszawa 2011, s. 217.

20 Armia Krajowa $w$ dokumentach 1939-1945, t. 1, cz. 2: Wrzesień 1939 - czerwiec 1941, red. A. Suchcitz, W. Grabowski [et al.], Warszawa 2015, s. 926 (Dok. 251: Gen. Rowecki do gen. Sosnkowskiego - Meldunek półroczny o stanie organizacyjnym ZWZ w Generalnym Gubernatorstwie, na ziemiach wcielonych do Rzeszy i pod okupacją sowiecką).

${ }^{21}$ M. Cabanowski, op. cit., s. 192-194. 
artylerii w Siłach Zbrojnych Południa Rosji (Вооружённые силы Юга России - BCЮP), a potem w sztabie 3. Armii Rosyjskiej gen. ltn. Nikołaja Bredowa. Po prawie dekadzie spędzonej w Polsce, Smysłowski ukończył niemiecką Akademię Sztabu Generalnego na przełomie lat dwudziestych i trzydziestych. Po kursie rozpoznawczym w Truppenamt związał się z niemieckim wywiadem wojskowym. W czasie II wojny światowej, rozpoczął służbę w stopniu Sonderführera (K) w ramach Stab Walli I-III oraz Sonderstab $\mathrm{R}^{22}$.

Smysłowski jako „von Regenau” kontaktował się z polskim podziemiem z organizacją szpiegowską „Muszkieterowie”, współpracującą z brytyjskim MI6. „Muszkieterzy” otrzymali w październiku 1941 r. od mjr. Smysłowskiego i ppor. Włodzimierza Bondorowskiego propozycję pomocy w przerzucie na sowieckie zaplecze grupy oficerów do Armii Polskiej gen. dyw. Władysława Andersa. Rosjanie w niemieckiej służbie i inż. Stefan Witkowski ps. „Inżynier” (szef „Muszkieterów”) mieli niezależnie od siebie nadzieje na pozyskiwanie materiałów wywiadowczych i korzyści politycznych, wynikających ze wspólnej akcji. Szef wywiadu ZWZ, płk Marian Drobik ps. „Dzięcioł”, zasygnalizował nawet dołączenie do misji dwóch oficerów. Szef „Muszkieterów”, „Inżynier”, miał przekonywać, że o wszystkim był poinformowany Komendant Główny ZWZ gen. bryg. Stefan Rowecki ps. „Grot”. Możliwość utworzenia łączności kurierskiej z gen. Andersem wydawała się atrakcyjną alternatywą. Kurierami zostali rtm. Czesław Szadkowski ps. „Mikołaj Zaręba” oraz trzech oficerów reprezentujących trzy rodzaje broni: ppor. Czesław Wasilewski ps. „Wilk” (piechota), por. Kazimierz Rutkowski ps. „Mątwa” (artyleria) i pchor. Antoni Pohoski ps. „Korejwo” (lotnictwo). Polacy wyruszyli 3 grudnia 1941 r. m.in. $\mathrm{w}$ towarzystwie ppor. Bondorowskiego, docierając via Łubianka do Buzułuku, gdzie znajdował się sztab gen. Andersa. Smysłowski mógł też rozpocząć współdziałanie z antykomunistyczną organizacją „Miecz i Pług”, która od lata 1942 r. była infiltrowana przez agenta NKWD/NKGB Bogusława Hrynkiewicza ps. „Aleksander”. Następnie poszukiwał kontaktów z Armią Krajową, która równocześnie rozpoznawała jego poglądy i otoczenie. Miało też dochodzić do prób rozmów sondażowych sojuszu „białej Rosji” z AK ${ }^{23}$.

Informacje, które pozyskał kontrwywiad AK nie deprecjonowały Rosjanina za współpracę z Niemcami:

${ }^{22}$ И. Грибков, И. Ковтун, Д. Жуков, Особый штаб „Россия”, Москва 2011, s. 32-66.

23 Archiwum Instytutu Pamięci Narodowej (dalej: AIPN) BU, 01222/3114, Notatka informacyjna, 18.07.1952, k. 69; И. Грибков, И. Ковтун, Д. Жуков, ор. cit., s. 148-149; K. Leski, Życie niewłaściwie urozmaicone. Wspomnienia oficera wywiadu i kontrwywiadu AK, Warszawa 1989, s. 129-131; J. Rostkowski, Świat Muszkieterów. Zapomnij albo zgiń, Poznań 2016, s. 176-183; R. Spałek, Komuniści przeciwko komunistom. Poszukiwanie wroga wewnętrznego w kierownictwie partii komunistycznej w Polsce w latach 1948-1956, Poznań-Warszawa 2014, s. 405-407; P.P. Wieczorkiewicz, Historia polityczna Polski 1935-1945, Poznań 2014, s. 404 oraz Д. Жуков, И. Ковтун, Борис Хольмстон-Смысловский и НТС. История сотрудничества и противостояния, w: История отечественной коллаборации. Материаль и исследования, Москва 2017, s. 316. 
Smysłowski Borys, p[od]pułk.[ownik], jakoby oficer gwardii carskiej, szef sztabu POA [ROA, a w zasadzie Sonderstab R - H.K.], urzędujący N. [owy] Świat 1 [faktycznie chodziło o kamienicę Pusłowskich przy Nowym Świecie 5, zaś drugie biuro Smysłowskiego mieściło w kamienicy przy ul. Chmielnej]. Z pochodzenia Finlandczyk, posiadający znaczne wpływy w Finlandii, Łotwie i Estonii. Nastawienie wybitnie anty-komunistyczne, ale nie pro-niemieckie. Mający duże sympatie dla Anglo-Amerykanów, orientujący się nieźle w stosunkach polskiej konspiracji, czytujący pilnie prasę konspiracyjną. Naogół do spraw polskich ustosunkowany życzliwie [pisownia oryginalna] ${ }^{24}$.

Dwie warszawskie książki telefoniczne z 1940 i 1942 r podawały jeszcze inne firmy Smysłowskiego. Prowadził z J. Bondorowskim firmę ślusarską (Schlosserei) przy ul. Hożej 61 z telefonem 89740 oraz w spółce z R. Mikuckim "Corporation” Mikucki R. u. Smyslowski B. GmbH Schleifmittel Wohn (Fabryka Materiałów ściernych, generalne Przedstawicielstwo Fabryki Norddeutsche Schleifmittel-Industrie w Hamburgu) przy Neue Burgstraße 46 (ul. Nowogrodzka), również z telefonem $73533^{25}$. Jednocześnie Smysłowski miał adresy prywatne - przed wojną mieszkał przy Parkowej 19 (tel. 884 20). O drugim adresie Smysłowskiego wspomina książka telefoniczna z 1942 r., w której ponownie występował jako inżynier - ul. Radna 8 (tel. 313 62). Trzeci adres płk. Smysłowskiego pojawił się w raportach kontrwywiadu AK, który ustalił, że mieszkał on niedaleko peronu kolejki konstancińskiej przy ul. Belwederskiej $32^{26}$.

Zapewne nie uszło to uwadze Niemców, którzy pod zarzutem działalności na dwie strony skierowali Borysa Smysłowskiego w grudniu 1943 r. do aresztu domowego. Jednocześnie jego struktura wywiadowcza i podległe mu oddziały dywersyjne zostały rozformowane. Internowanie Smysłowskiego było efektem przekazania do Dowódcy Policji Bezpieczeństwa na Dystrykt Warszawa (Komandeur der Sicherheitspolizei Warschau - KdS Warschau) informacji przez szwajcarskiego dziennikarza pochodzenia rosyjskiego, Aleksandra Würglera, o związkach Smysłowskiego z wolnomularstwem i wywiadem brytyjskim. W ten sposób zemścił się on za podobny akt Smysłowskiego i wykluczenie z Sonderstab Russland. Tymczasem Würgler został zastrzelony w przeddzień Wigilii Bożego Narodzenia na warszawskim Starym Mieście - najprawdopodobniej przez AK, choć nie można wykluczyć innych podmiotów. W grę wchodziło KdS Warschau, komuniści, powiązani z PPR/GL-NKWD/NKGB, podwładni Smysłowskiego lub jego konkurenci z Ludowo-Pracowniczego Związku (Rosyjskich Solidarystów) Народно-трудовой союз (российских солидаристов) - HTC/NTS. Pół roku

24 AAN, 228/8-2, Społeczny Komitet Antykomunistyczny - „Antyk”, (Komitet rosyjski, Pułk. Smysłowski), 17.03.1944, k. 95.

25 Amtliches Fernsprechbuch für den Distrikt Warschau 1942, Warschau 1942, s. 34, 114 i 160 oraz Telefonverzeichnis der stadt Warschau [wykaz czynnych telefonów warszawskiej sieci], Warszawa 1940, s. 121 i 166.

${ }^{26}$ Amtliches Fernsprechbuch..., s. 160; Spis abonentów sieci telefonicznej m. st. Warszawy P.A.S.T. i warszawskiej sieci okręg P.P.T.T. Rok 1939/40, Warszawa 1939, s. 392. 
później Smysłowski został uwolniony od zarzutów. Równocześnie, mimo zorientowania się, że działania płk. Smysłowskiego nie są wymierzone w Polskie Państwo Podziemne, AK odpowiedziała 17-18 maja 1944 r. nieudaną próbą zamachu na tego „pułkownika wojsk ukraińskich”. Błędne określenie na odprawie przed akcją jako Ukraińca mogło tylko wzmóc bojowe nastroje żołnierzy Kedywu Okręgu Warszawskiego AK, wiedzących o tragicznym losie Polaków na Wołyniu ${ }^{27}$.

W tej akcji wziął udział Stanisław Aronson z Oddziału Dyspozycyjnego Kedywu OW AK „Kolegium A”:

Wspomnieniem traumatycznym była nieudana próba likwidacji Borysa Smysłowskiego. Ciągnęła się ona dwa dni bez żadnego rezultatu. Wówczas zginął „Żbik” [ppor./por. Zdzisław Zajdler-Rybicki - H.K.] - to był straszny cios po 10 miesiącach wspólnej walki stracić dowódcę. Tego dnia czekaliśmy na końcowej stacji kolejki wilanowskiej [konstancińskiej]. Pociągi odjeżdżały i przyjeżdżały, a my czekaliśmy, co nas zdradziło. „Rena” [Renata Brenstiern-Pfanhauser, od 1948 r. - Rostworowska] zauważyła dwóch szpicli, którym wydaliśmy się podejrzani. Chwilę potem „Żbik” dał sygnał do natychmiastowego odwrotu. Ale było za późno - właśnie jemu i „Kaczorowi” [NN] nie udało się. Obaj zostali zaatakowani przez niemiecką policję i zginęli u wejścia do budynku przy ul. Olszewskiej. Inni zdołali uciec. Obecnie się okazuje, że zginęli na darmo - a myśmy mogli wykonywać zlecenie sowieckich agentów w brytyjskim Secret Intelligence Service, tych od Kima Philby’ego i „Piątki z Cambridge”. Bo Smysłowski był wrogiem Sowietów, a nie Polaków, których znał, bo mieszkał w Warszawie od lat $20^{28}$.

W raporcie na temat Smysłowskiego, sporządzonym dwa tygodnie po nieudanym zamachu na niego, kontrwywiad AK przekazywał całkowicie odmienne informacje, które wcale nie powinny być podstawą do wydania nań wyroku śmierci. Rosyjski oficer $\mathrm{w}$ niemieckiej służbie należał od przedwojnia do Zakonu Martynistów oraz loży symbolicznej Starożytnego i Pierwotnego Rytu Egipskiego Wschodniego Memphis-Misraim pod nazwą: „Piramida Północy w Dolinie Wisły" nr 16 (La Pyramide du Nord en la Vallée de la Vistule) ${ }^{29}$. Oto

27 AAN, 228/8-2, Społeczny Komitet Antykomunistyczny - „Antyk”, Referat rosyjski, Załącznik $\mathrm{nr} 4$, 8.12.1943, k. 87; Генерал Власов. История предательства, т. 1: Нацистский проект „Aktion Wlassow”, ред. А.Н. Артизов, Москва 2015, s. 855 (№. 315. Донесение сотрудника отдела «иностранные армии Востока» при Генштабе окх оберлейтенанта Баума генерал-майору р. Гелену о персональном составе штаба А. А. Власова и антинемеиких установках членов этого штаба, 10.01.1945]; S. Aronson, P. Bukalska, Rysiek z Kedywu. Niezwykłe losy Stanisława Aronsona, Kraków 2009, s. 99; J.D. Zimmerman, The Polish Underground and the Jews, 1939-1945, Cambridge - New York 2015, s. 332-333 oraz Uciekłem z transportu, trafitem do Kedywu. Ze Stanisławem Aronsonem, pseudonim „Rysiek” rozmawia Marcin Urynowicz, „Biuletyn Instytutu Pamięci Narodowej” (2008), nr 8-9, s. 131-132.

28 Relacja Stanisława Aronsona, 4.08.2012, w archiwum autora.

${ }^{29}$ Loża Starożytnego i Pierwotnego Rytu Egipskiego Wschodniego Memphis-Misraim liczyła w latach 30. XX w. kilka osób. Jego trzon tworzyli Jan Korwin Czarnomski „Elpher”, pełniący funkcję Wielkiego Mistrza Świateł, czyli szefa organizacji; Borys Smysłowski „Hermes”, przewodniczący kapituły „Pelikan” i Wielki Konserwator Obrządków oraz Robert Walter „Waltari”, 
fragment raportu o przyjacielu Smysłowskiego Janie Korwinie Czarnomskim (pisownia oryginalna):

Nawiązane w Paryżu stosunki z pułkownikiem S.[mysłowskim] podtrzymał i tutaj. Był o panu S.[mysłowskim] jak najlepszego mniemania, dużo opowiadając o jego życzliwości dla Polaków i o ratowaniu przez niego takich, którzy zostali już na śmierć skazani. W jednym wypadku miał podobno wyciągnąć kogoś już z samochodu, wiozącego na stracenie. Jesienią 1943 r. (w listopadzie) pułk. [ownik] S.[mysłowski] zwrócił się do niego z propozycją wyjazdu wraz z nim do Francji w charakterze prywatnego sekretarza. [...] Pragnę tu jeszcze dodać, iż już proponując podróż do Paryża, pułk.[ownik] S.[mysłowski] powiedział $\mathrm{Cz}$ [arnomskiem]-u, iż celem ostatecznym tej wyprawy jest nawiązania kontaktów z aljantami, bo przecie oni tylko będą zwycięzcami ${ }^{30}$.

Uzupełnieniem informacji kontrwywiadu AK były wiadomości zasłyszane przez byłego oficera AK, pracującego po wojnie jako agent UB. Oto co po wojnie przekazał agent UB Juliusz Wilczur-Garztecki, siedzący w celi z nieświadomym tego Robertem Walterem (przyjacielem i wolnomularskim powiernikiem Smysłowskiego):

Snuje on przypuszczenia, że w związku z jego przyjaźnią ze Smysłowskim MBP będzie chciało zaangażować go do pracy jako „przynętę” na Smysłowskiego. [...] Na prośbę Waltera Smysłowski przez swój aparat prowadził śledztwo w sprawie morderstwa [Czarnomskiego - H.K.] i ustalił, że Piwnicka [Katarzyna, narzeczona Czarnomskiego] związana jest z jakąś organizacją konspiracyjną. [...] Podałem wówczas Walterowi, że wg moich wiadomości z O.[ddziału] II AK Czarnomski był zamordowany przez bandę [grupę] Andrzeja Sudeczki na zlecenie O.[ddziału] II NSZ z tzw. „listy żydokomuny w Sztabie AK”31.

Wielki Kofta i Tajny Radca. Członkami rytu byli też: Stanisław Korwin Czarnomski (brat Jana) i Ryszard Walter (brat Roberta). W łonie rytu trwała do 1937 r. rywalizacja między J. Czarnomskim a Smysłowskim, a potem „zsynchronizowali” swoją działalność, przy czym Smysłowski miał zajmować się wywiadem na kraje północne i germańskie. Jako plotkę można uznać „informację" o rozkładaniu Uniwersalnej Federacji Inicjacyjnych Zakonów i Stowarzyszeń (Fédération Universelle des Ordres et Sociétés Initiatiques - FUDOSI). W czasie wojny Rosjanin, mimo służby w Fremde Heere Ost pozostawał lojalny wobec swej loży - w początkach $1944 \mathrm{r}$. ułatwił J. Czarnomskiemu (druga wersja mówi o jesieni 1943 r. i R. Walterze) przewiezienie archiwum rytu do Budapesztu, zob.: Centralne Archiwum Wojskowe (dalej: CAW), IX.3.26.3, Armia Krajowa. Komenda Główna, Oddział VI [faktycznie Oddział II B (kontrwywiad) KG AK, Referat 996], [meldunek nt.] Walter Robert - Tajny Zakon Martynistów i Memphis Misraim, k. 17; [meldunek nt.] CZARNOMSKI Jan - brat ELPHER Wielki Mistrz obrządku Memphis Misraim i Martynistów - zabity 260744, k. 29; AIPN BU, 01222/ 3144, Odpis: Borys Smysłowski, k. 23; Z. Łagosz, Robert Walter's Struggle with the UB: the Unknown Story, „Studia Religiologica” 46 (2013), nr 4, s. 298-299.

30 AAN, 203/ VII-4, Oddział II Informacyjno-Wywiadowczy Komendy Głównej AK, 996-W, [Raport „Wacława” na temat] Jan Czarnomski; 10.07.1944, k. 19-20.

31 AIPN BU, 00168/79, t. 8, Teczka pracy krypt. „Natan” [Wilczur Garztecki Juliusz], k. 238, 241 oraz Z. Łagosz, op. cit., s. 298-299 i 303-304. 
Smysłowski pozostawał lojalny wobec swej loży, gdy w początkach 1944 r. ułatwił Janowi Czarnomskiemu przewiezienie archiwum organizacji do Budapesztu. Czarnomski prosił Smysłowskiego o sprawdzenie, czy Katarzyna Piwnicka ps. „Ketti” nie pracowała dla KdS Warschau. Rosjanin odkrył, że „Ketti” współpracowała $\mathrm{z}$ agencją detektywistyczną. Po wojnie UB uznało Piwnicką za powiązaną z wywiadem Okręgowej Delegatury Rządu Warszawa-Miasto „Wiry-Mury” kierowanym przez Wiktora Boczkowskiego ps. „Korwin”. Wcześniej Czarnomski żałował w rozmowach z przyjaciółmi, że Piwnicka nie pracowała dla Intelligence Service. Ponadto ostrzegał go przed kontaktami z nią, gdyż miała ona być jednym z ważniejszych pracowników Brygady Korwina [ppłk Wiktor Franciszek Boczkowski-Boćkowski, ps. „Korwin”] - jednego z oddziałów kontrwywiadu ZWZ- AK działającym na terenie Warszawy ${ }^{32}$.

Jeden $\mathrm{z}$ konspiratorów informował o tym $\mathrm{w}$ swym meldunku na podstawie przeprowadzonego rozpoznania: „W/g jego [oficera kontrwywiadu Adama Leszczyca-Gutowskiego ps. „Bratkowski”] informacji Ketti była sekretarką Smysłowskiego, dzięki czemu Korwin posiada rozpracowanym przez nią cały sztab armii Własowa [Sonderstab Russland]". Za to w dalszej części tego samego dokumentu zaprzeczał mu Czarnomski indagowany przez przedstawiciela kontrwywiadu AK:

Czarnomski twierdzi, że była w nim zakochana i sam nawet przez krótki okres chciał się jej oświadczyć, co mu jednak odradził Smysłowski zwracając uwagę jego na Ketti jako na osobę mogącą być niebezpieczną dla Czarnomskiego. [...] Ketti poprosiła Czarnomskiego o ułatwienie jej takiej sprawy, którą jak ten twierdzi mógł dobrze załatwić tylko Smysłowski. Na skutek tego Cz.[arnomski] skontaktował ją ze Smysłowskim i jak podaje [Czarnomski] była u niego jeden raz w sztabie Własowa [Sonderstab Russland], poczem starała się usilnie za pomocą telefonów pod najróżniejszymi pretekstami, podtrzymywać ten kontakt, co jak podaje Czarnomski nie udało się jej. Smysłowski zwrócił uwagę Czarnomskiego, że Ketti wygląda na osobę mającą jakąś styczność z G[esta]po, nie miał na to jednak podobno żadnych konkretnych dowodów i opierał się tylko na osobistym wrażeniu. [...] Ketti ma duże stosunki w świecie konspiracyjnym zwłaszcza od strony NSZ ${ }^{33}$.

Smysłowski, będąc internowany przez Niemców, nie miał szans na ocalenie wolnomularskiego przyjaciela. Jan Czarnomski został zabity 27 czerwca $1944 \mathrm{r}$. przez nieznanych sprawców. W grę wchodził napad rabunkowy, omyłkowe zastrzelenie za prof. Czarnowskiego (zbieżność nazwisk) lub akcja wymierzona w lewicową część ruchu oporu, wolnomularzy i Żydów, czyli powiązana z zamordowaniem Ludwika Widerszala i Jerzego Makowieckiego przez żołnierzy oddziału

32 CAW, IX.3.26.3, Armia Krajowa, Komenda Główna, Oddział VI [faktycznie Oddział II B (kontrwywiad) KG AK, Referat 996], [meldunek nt.] Piwnicka Katarzyna - Ketti, k. 20; O. Borzęcki, Brygada Korwina $w$ szeregach ZWZ-AK w latach 1941-1943, „Dzieje Najnowsze” 47, 2015, nr 3, s. 52 oraz Z. Łagosz, op. cit., s. 304-305.

33 CAW, IX.3.26.3, Armia Krajowa, Komenda Główna, Oddział VI [faktycznie Oddział II B (kontrwywiad) KG AK, Referat 996], [meldunek nt.] Piwnicka Katarzyna - Ketti, k. 20-21. 
dywersyjnego Andrzeja Popławskiego ps. „Andrzej Sudeczko”, podporządkowanego Państwowemu Korpusowi Bezpieczeństwa. Innym wykonawcą mogła być organizacja Henryka Glassa „Blok”, wywodząca się z przedwojennego Porozumienia Antykomunistycznego, działająca jako Biuro „W” w II Oddziale KG AK oraz jako Brygada Obserwacyjna „Lisy” w NSZ ${ }^{34}$.

Po zamachu AK dalsze kontakty płk Smysłowski utrzymywał tylko z podziemiem narodowym - NSZ. Od drugiej połowy 1944 r. przy sztabie Smysłowskiego znajdował się patrol łącznikowy Brygady Świętokrzyskiej w składzie: por. Przemysław Andrzej Łebiński (po wojnie Władysław Przemysław Szaława/ Przemysław Mieczkowski) ps. „Władysław”, „Przemysław Szaława”, kpt Zdzisław Przybył ps. „Rafał Olbromski” oraz sierż. RAF/Sergeant (por. RAF/ Flying officer) Richard V. Tullet ps. „Harry”35, który po ucieczce z obozu jenieckiego działał w składzie NSZ. Kilka tygodni przed końcem wojny 1. Rosyjska Dywizja Narodowa/ Dywizja Specjalna R (1. Russische Nationaldivision/Sonderdivision R) 4 kwietnia 1945 została przemianowana na 1. Rosyjską Armię Narodową (1. Russische Nationalarmee - 1. RNA), sprzymierzoną z Niemcami. Smysłowski został awansowany na stopień generała majora Wehrmachtu. Cały czas przebywali w sztabie „von Regenau” polscy emisariusze z NSZ. Następnie 10 kwietnia 1945 por. Łebiński został wysłany z zadaniem nawiązania łączności z dowództwem II Korpusu we Włoszech (via Niemcy, Szwajcarię, Francję). W czasie pobytu w polskim związku był on przydzielony do Rezerwy Oficerskiej 7. DP. Do Brygady Świętokrzyskiej powrócił 5 lipca $1945 \mathrm{r}$.

Pod ostatnich dniach kwietnia 1945 r. gen. Smysłowski skierował się z pozostałymi przy nim żołnierzami 1. RNA oraz następcą tronu rosyjskiego, wielkim księciem Władimirem Romanowem i Siergiejem L. Wojciechowskim do Liechtensteinu. Niezależne księstwo odmówiło wydania Sowietom generała i jego podwładnych. Rzeczywiście, umowy jałtańskie dotyczące repatriacji obywateli i jeńców sowieckich nie obejmowały tego neutralnego terytorium ${ }^{36}$.

${ }^{34}$ CAW, IX.3.26.3, Armia Krajowa, Komenda Główna, Oddział VI [faktycznie Oddział II B (kontrwywiad) KG AK, Referat 996], [meldunek nt.] Walter Robert - Tajny Zakon Martynistów i Memphis Misraim), k. 17; S. Bojemski, Likwidacja Widerszala i Makowieckich, „Glaukopis” 2007-2008, nr 9/10, s. 370 oraz J. Marszalec, Morderstwo na Makowieckich $i$ Widerszalu. Stara sprawa, nowe pytania, nowe wątpliwości, „Zagłada Żydów. Studia i Materiały” 2 (2006), s. 47.

$35 \mathrm{Na}$ liście zestrzelonych lotników RAF z Bomber Command, którzy zostali jeńcami wojennymi, widnieje jedynie nazwisko podoficera RAF - bombardiera: Sgt Tullett R. M., 77 Dywizjonu Bombowego RAF, który został zestrzelony w nocy 16/17.04.1943 podczas nalotu na Pilzno w samolocie Handley Page Halifax KN-W (JB908). Po dostaniu się do niewoli trafił ostatecznie jako jeniec do Stalagu 357 (Thorn [Toruń]), zob.: https://www.forces-war-records.co.uk/records/4158477/ sergeant-r-m-tullett-royal-air-force/ (dostęp: 17.01.2017).

36 Rozkazy dzienne Brygady Świętokrzyskiej Narodowych Sił Zbrojnych 1944-1945, oprac. C. Brzoza, Kraków 2003, s. 209-210; A. Bohun-Dąbrowski, Byłem dowódca Brygady Świętokrzyskiej NSZ Pamiętnik dowódcy, świadectwa żolnierzy, dokumenty, Warszawa 1989, s. 149, 172 oraz И. Грибков, И. Ковтун, Д. Жуков, оp. cit., s. 278-279, 288-297 і 312-314. 


\section{Warszawscy konspiratorzy - bracia Kotliarewscy}

W czasie okupacji niemieckiej los związał Stefana Korbońskiego, członka Politycznego Komitetu Porozumiewawczego (PKP) oraz naczelnika Komitetu Walki Cywilnej przy Delegaturze Rządu RP na Kraj (KWC) z kilkoma emigrantami rosyjskimi. Podczas okupacji niemieckiej miało miejsce tragiczne wydarzenie w „rosyjskiej” Warszawie. Było ono związane z braćmi Kotliarewskimi, o których uwolnienie Siergiej Wojciechowski zabiegał podczas spotkań z licznymi wpływowymi osobami we władzach niemieckich:

W liczbie takich [polskich - H.K.] „agentów”, znaleźli się niektórzy Rosjanie, w tym były redaktor „Naszego czasu” [Наше Время] ${ }^{37}$ i „Słowa rosyjskiego” [Русское Слово] T. A. [Teokryt (Feokist) Ananiewicz] Kotliarewskij i jego brat - Eugeniusz [(Jewgienij) Ananiewicz $]^{38}$.

W mieszkaniu T. A. Kotliarewskiego [przy ul. Zgody 6 m. 4] został aresztowany jego krewny, Polak, u którego były znalezione nielegalne polskie druki. To wystarczyło, aby wszyscy, którzy mieszkali w mieszkaniu zostali aresztowani, a następnego dnia T. A. Kotliarewskij i jego krewny [powinno być: krewni] znaleźli się wśród „agentów”, podlegających rozstrzelaniu. Wszystkie wysiłki przewodniczącego Komitetu Rosyjskiego S. L. Wojciechowskiego, aby uratować T. A. Kotliarewskiego nie powiodły się, a kilka dni później przeczytaliśmy jego nazwisko ponownie - na liście rozstrzelanych. Jego brat zginął z powodu własnej nieostrożności - w chwili aresztowania wszystkich przebywających w mieszkaniu nie było go w domu. Funkcjonariusze Gestapo zamknęli puste mieszkanie i wzięli klucze ze sobą. Następnego dnia E. A. Kotliarewskij, dowiedziawszy się o tych aresztowaniach, mimo ostrzeżeń przyjaciół, zachował się nieostrożnie, idąc po klucze do mieszkania do Gestapo. Stamtąd nie wrócił, a kilka dni później i on pojawił się w wykazie rozstrzelanych „agentów”. Obaj bracia Kotliarewscy byli dobrze znani w naszej warszawskiej kolonii rosyjskiej i, oczywiście, nie byli żadnymi „agentami” i nie brali udziału w działalności polskich organizacji antyniemieckich.

37 „Nasz czas” („Наше Время”) ukazywał się pod redakcją G.A. Macijewskiego (1930-1932), a następnie S.M. Goriaczko (od października 1932 do lipca 1933 r.), później T.A. Kotliarewskiego, z siedzibą redakcji w Wilnie oraz oddziałami w Warszawie oraz we Lwowie. Nad Wilią był drukowany w drukarni E.A. Kotliarewskiego, podobnie jak późniejsze, „Русское Слово” (nowe wcielenie „Наше Время”, różniące się tylko tytułem). Gazeta Kotliarewskich była dystrybuowana wspólnie z ryską gazetą rosyjskojęzyczną „Сегодня” (w rzeczywistości „Наше Время” były regionalnym dodatkiem do „Сегодня”).

${ }^{38}$ Eugeniusz Kotliarewskij jako doświadczony wydawca i dziennikarz dołączył do Józefa Mackiewicza oraz Czesława Ancerewicza jako współwłaściciel, wydający wileński dziennik „Goniec Codzienny" pod kontrolą niemieckiej Propaganda Abteilung. Negatywnie o Kotliarewskim wypowiadała się Teresa Jurgielewiczowa („o bardzo zszarganej opinii”, „też miał swój wyrok [śmierci]”). Tej drugi informacji zaprzecza Lucjan Krawiec („Sprawa Kotl[i]arewskiego jako nie Polaka [Rosjanina], nie była przez Sąd Specjalny rozpatrywana i wyrokowana"), zob.: W. Bolecki, Ptasznik z Wilna. O Józefie Mackiewiczu. Zarys monograficzny, Kraków 2013, s. 275,279 i 303. 
Tak - w 1943 r. - myślałem i ja, ale teraz wiem, że próba uratowania T. A. Kotliarewskiego od rozstrzelania była nie tylko nieskuteczna, ale beznadziejna. A[natol] P. Wielmin pomylił się, sugerując, że T. A. Kotliarewskij nie był zaangażowany w walkę polskich tajnych organizacji z niemiecką okupacją. Prawdę dowiedziałem się w 1954 r. ze wspomnień byłego stojącego na czele polskiego ruchu oporu, adwokata Stefana Korbońskiego ${ }^{39}$.

Oto co napisał Stefan Korboński w swych powojennych wspomnieniach o epizodzie z trójką Rosjan, współpracujących z Armią Krajową i Komitetem Walki Cywilnej przy Delegaturze Rządu RP na Kraj:

Na początku 1944 [1943 - H.K.] roku, [...] nasza centrala mieściła się na ulicy Zgoda [Zgoda 6 m. 4], blisko Chmielnej, w mieszkaniu docenta [doktora] botanika Wiszniewskiego [Tadeusza Wiśniewskiego] ${ }^{40}$, lub bardziej precyzyjnie, jego teścia „białego” Rosjanina, przed wojną redaktora rosyjskiego emigracyjnego pisma w Warszawie [Wilnie]. Otwierał on mi nieraz drzwi, ale nie zamieniliśmy ze sobą przez cały czas ani jednego zdania. Wiszniewski z czasem zaczął dla nas pracować, między innymi chował nasze papierki w swoich zielnikach. Parę tysięcy teczek, z zasuszonymi roślinami, leżało na drewnianych półkach w jego pokoju i w nich zrobiliśmy przejściowo nasze archiwum. Wiszniewski opowiadał mi, że jego teść nie tylko, że trzymał się od tych białych Rosjan i ich organizacji w Polsce [Generalnym Gubernatorstwie], które poszły na współpracę z Niemcami, nieraz jedynie dla lepszych kartek żywnościowych, ale przeciwnie uważa, że korzystając przez tyle lat z gościnności polskiej, Rosjanie nie powinni na terenie Polski [Generalnego Gubernatorstwa] prowadzić

39 С.Л. Войцеховский, Эпизоды..., s. 405-407 (Wojciechowski był korespondentem rosyjskojęzycznej, berlińskiej gazety „Новое слово”. Ewakuował się 30.07.1944 z Warszawy do Niemiec).

40 Tadeusz Wiśniewski (25.05.1905 Taganrog - 30.11.1943 Warszawa). Botanik (Uniwersytet Warszawski, doktor 1930) i fitogeograf, alpinista, naukowiec. Był znawcą i kolekcjonerem mchów oraz miłośnikiem wypraw naukowo-badawczych. Wiśniewski podróżował do Bułgarii, Jugosławii, Laponii, uczestnik wyprawy na Kaukaz (1935), Ruwenzori (1939) i innych. Wyprawa afrykańska „kosztowała” go etat na UW. Efektem tych podróży były liczne, cenne zielniki - w szczególności mchów. Prowadził badania botaniczne w Tatrach. W roku 1923 Wiśniewski ogłosił kilka artykułów i prac botanicznych, częściowo dotyczących flory Tatr. Najważniejszą jego pracą była dysertacja: Les associations de Muscinées (Bryophyta) épiphytes de la Pologne, en particulier celles de la forèt-vierge de Białowieża (Zespoly mszaków epifitycznych Polski ze szczególnym uwzględnieniem Puszczy Białowieskiej) - „Bulletin international de l'Académie polonaise des sciences et des lettres, Classe des sciences mathématiques et naturelles”, Série B, I Cracovie, (1929), nr 8-10. Kolekcja przetrwała wojnę ukryta w Państwowym Muzeum Zoologicznym. Wiśniewski przygotowywał monografię polskich mchów, której nie skończył z powodu przedwczesnej śmierci. Po wybuchu wojny niemiecko-polskiej ewakuował się do Poleskiej Stacji Hydrobiologicznej w Pińsku, stamtąd trafił do Lwowa, a w 1941 r. wrócił do Warszawy. W czasie II wojny światowej uczestniczył w tajnym nauczaniu w Warszawie. Pomagał przy ewakuacji i ukryciu zbiorów Zakładu Systematyki i Geografii Roślin Uniwersytetu Warszawskiego. Został aresztowany przez funkcjonariuszy KdS Warschau i rozstrzelany 30.11.1943 razem z innymi zakładnikami przy ul. Solec 63, nieopodal kościoła oo. trynitarzy, zob.: A. Iwaszkiewiczowa, Dzienniki i wspomnienia, Warszawa 2000, s. 599; A. Skirgiełł, Powstanie i rozwój Zakładu Systematyki i Geografii Roślin Uniwersytetu Warszawskiego (w zarysie), Warszawa 2001, s. 12-13 i 15-16; B. Hryniewiecki, Tadeusz Wiśniewski (1905-1943). Wspomnienie pośmiertne, „Acta Societatis Botanicorum Poloniae" 19 (1948), nr 2, s. 275-280. 
polityki przeciwnej interesom [okupowanych] gospodarzy. Może wchodziły tu w grę i inne racje, np niechęć do wspólnej akcji z Niemcami przeciw Rosji - nawet sowieckiej, dość, że mieliśmy do naszej dyspozycji mieszkanie u Rosjanina ${ }^{41}$.

Niemcy aresztowali jesienią 1943 r. niejakiego Wosińskiego, który po torturach naprowadził ich na osobę sekretarza KWC Tadeusza Kiełczewskiego ps. „Rudy”. Kilka dni później funkcjonariusze KdS Warschau po „złamaniu” kolejnego konspiratora pojawili się w lokalach KWC przy ulicy Zgoda i Leszczyńskiej. „Kocioł” w tym pierwszym mieszkaniu przyniósł aresztowanie Stanisława Kętrzyńskiego, Tadeusza Wiśniewskiego, Niny i Teokryta Kotliarewskich. Korboński wspominał dalej:

Rozmówiłem się z Wiszniewskim [Wiśniewskim] i zażądałem, by wszyscy opuścili mieszkanie przynajmniej na jakiś czas, i ukryli się. Zaofiarowałem pomoc pieniężną, fałszywe dokumenty itp. Wiszniewski, jednak odmówił, twierdząc, po pierwsze, że jeśli „Rudy” aresztowany, to i tak nic nie powie, bo jest twardy i z charakterem, po drugie jego teść i żona stanowczo odmówili opuszczenia mieszkania, po trzecie lokal jest wyczyszczony do ostatniej nitki i Gestapo nic w nim nie znajdzie. Kiwałem głową na to wszystko z powątpiewaniem. Nie ręczyłbym za nikogo, również za siebie, jeśli chodzi o tortury. Skąd można wiedzieć? Ale trudno! Nie chcą - to nie. A może „Rudy” nie aresztowany, tylko zwiał na prowincję? Miałem głowę zajętą już mnóstwem innych spraw, związanych ze zniknięciem „Rudego” i o mieszkaniu na Zgoda przestałem myśleć. Za kilka dni przyszła zła nowina. Gestapo najechało w nocy na lokal i zabrało wszystkich. [...] Stępieliśmy już w czwartym roku wojny na tego rodzaju sprawy i nikt ich tak żywo już nie odczuwał jak na początku okupacji. [...] Jednak prawie, że się załamałem, gdy przebiegając oczyma jakiegoś poranka czerwony afisz z nazwiskami osób rozstrzelanych w publicznej egzekucji, natknąłem się na nazwiska Wiszniewskiego i jego teścia. Spojrzałem raz i drugi nie chcąc wierzyć własnym oczom. Mimo wszystko, nie byłem przygotowany na tak szybki koniec. Nie było jednak wątpliwości. Wielkie czarne litery na czerwonym tle głosiły wyraźnie: „Wiszniewski”. Tak zginął młody, obiecujący uczony, a wraz z nim na marginesie naszej walki z Niemcami, szlachetny Rosjanin ${ }^{42}$.

Niemcy zabili wszystkich aresztowanych, z wyjątkiem Kętrzyńskiego. Rozstrzelanie obu Rosjan i dr. Wiśniewskiego miało miejsce w czasie realizacji „ostrego kursu Kutschery”. Okres wzmożonych represji w dystrykcie warszawskim GG zakończył 1 lutego 1944 r. udany zamach na SS- und Polizeiführer Warschau, SS-Brigadeführera und Generalmajora der Polizei, Franza Kutscherę zabitego przez Kedyw KG $\mathrm{AK}^{43}$.

41 S. Korboński, W imieniu Rzeczypospolitej, Warszawa 2009, s. 318.

42 W. Grabowski, Polska Tajna Administracja Cywilna 1940-1945, Warszawa 2003, s. 248 oraz S. Korboński, op. cit., s. 452-455,

43 AAN, 202/ II-17 [mikrofilm 2225/3], k. 22-23 (St.K.W. [Raport Komórki Więziennej Delegatury Rządu - „Stożka”]; 25 XI 1943); k. 24 (St.K.W., Ściśle tajne, 25 XI 1943); k. 27 (St.K.W., 9 XII 1943) oraz S. Korboński, op. cit., s. 319-320. 
Istnieje jeszcze trzecia relacja dotycząca aresztowania Kotliarewskich i Wiśniewskiego, częściowo pokrywająca się z dwiema wcześniejszymi:

Czasem bywałam na ulicy Zgody. Fabrykowałam dla niego na czerpanym papierze Błońskiego metryki pisane gotykiem. Zajmowałam się tą czynnością w listopadzie $1943 \mathrm{r}$. Któregoś dnia Wiśniewski poprosił mnie o przysługę. Wyciągnął spod okładek starej książki pochowane tam kawałeczki bibułki z nazwiskami i adresami, złożone w harmonijkę. Prosił o przekazanie pod wskazany adres. [...] Trzeba było usunąć wszelkie ślady AKowskie z mieszkań, które mogły być znane gestapo. Zareagowałam natychmiast. Błagam go, by natychmiast poszedł ze mną na Nowogrodzką [...]. Podziękował. Tłumaczył, że nie skorzysta, zresztą ma już lokum [...]. Wiśniewski twierdził, że Nina zaraz wróci, ale już jest późno by się przeprowadzać.

Przed świtem, o piątej rano. Wiśniewski i Kotlarewska zostali aresztowani. Wsiadali do budy. On bez nakrycia głowy, ale za to z małą maszyną do pisania. Moment wyprowadzania widzieli przez okno moi znajomi mieszkający vis-à-vis [...]. Natychmiast zawiadomiłam Mirkę o smutnym zajściu. Bardzo się przejęła, posłała paczkę żywnościową i beret. Nie znaleziono możliwości wyciągnięcia go z aresztu. Na kolejnej czerwonej liście rozplakatowanej na wszystkich słupach ogłoszeniowych, obejmującej nazwiska rozstrzelanych zakładników odnalazłam i jego. Zakończył życie 30 listopada 1943 r. Miesiąc później na kolejnej liście znalazłam nazwisko [Eugeniusza] Kotliarewskiego [faktycznie 14.12.1943], brata Niny. Przyjechał z Wilna i zgłosił się na Gestapo po klucze do mieszkania zajmowanego przez siostrę, mając nadzieję, że nic mu nie grozi. Nina, chora na wątrobę, nie przetrzymała Pawiaka [zmarła 10.03.1944] ${ }^{44}$.

\section{Dwaj pułkownicy - Władimir Brand i Nikołaj Tumanow}

Oficerem rosyjskim, związanym z Sonderstab R oraz polskim ruchem oporu był Władimir Brand. Urodził się 17 lipca 1892 r. w guberni tulskiej. Po Nikołajewskim Korpusie Kadetów ukończył w 1912 r. studia w Michajłowskiej Szkole Artylerii. $\mathrm{W}$ armii rosyjskiej walczył do zdemobilizowania w $1917 \mathrm{r}$., awansując do stopnia kapitana artylerii. Potem został wcielony w 1918 r. w Armii Czerwonej, następnie przeszedł do Brygady Tulskiej jako dowódca samodzielnego dywizjonu artylerii lekkiej. Dowodził nim w ramach Sił Zbrojnych Południa Rosji i armii Ukraińskiej Republiki Ludowej. Służył aż do awansowania 25 marca 1919 r. na podpułkownika w szeregach gen. Nikołaja Judenicza, a później Rosyjskiej Ludowej Armii Ochotniczej ${ }^{45}$. Pod koniec tego roku emigrował do Polski, gdzie wstąpił do Związku

44 A. Skirgiełło, Zapiski ze stuletniego życia, Warszawa 2006, s. 83 („Wiśniewski mając w dowodzie wpis «żonaty», zgłosił Ninę Kotliarewską jako «żonę» podczas poniewierki na terenach przyłączonych do ZSSR. Najpierw zaopiekowała się nim Nina w Pińsku, a wkrótce, unikając aresztowania oboje wyjechali do Lwowa, gdzie role się odmieniły. $Z$ tego powodu żona Wiśniewskiego, Mirka z domu Sidorowicz doprowadziła do rozwodu, a botanik już naprawdę ożenił się z Niną, przechodząc na prawosławie”, zob.: ibidem, s. 81).

45 P. Mitzner, Warszawski krag Dymitra Fiłosofowa, Warszawa 2015, s. 138-139. 
Obrony Ojczyzny i Wolności (Союз защиты Родины и Свободы) kierowanego przez Borysa Sawinkowa. Poza tym, że był doświadczonym oficerem, stał się uznanym poetą, należącym do Tawerny poetów ${ }^{46}$, a od końca lat 20 uczestniczył w Społeczności Literackiej (Литературное содружество) ${ }^{47}$. Był dziennikarzem i redaktorem w pismach Dymitra Fiłosofowa: „Za wolność!” („За Свободу!”) od 1927 do 1932, „Wieść” („Молва”) w latach 1932-1934 oraz od połowy 1934 do 1939 r. tygodniku „Miecz” („Меч”) ${ }^{48}$. Brand nie zaniedbywał aktywności lirycznej - opublikował zbiór poetycki Cmuxu wydany na powielaczu w Warszawie w 1932 r., był współautorem Антологии русской поэзии в Польще, opublikowanej w 1937 r. w Warszawie oraz zbioru Новb ${ }^{49}$.

O literacko-dziennikarskim zaangażowaniu Branda pisał Siergiej Wojciechowski:

W. W. Brand był ze wszystkich współpracowników „Молвы” najbliżej Fiłosofowa. Ich łączyło przeszłe uczestnictwo w sawinkowskim Ludowym Związku Obrony Ojczyzny i Wolności [Народный Союз Защиты Родины и Свободы]. Po jego rozbiciu Brand

46 Tawerna poetów (Таверна поэтов) - warszawski krąg literacki założony na początku $1921 \mathrm{r}$. przez Alfreda Bema. Uczestnikami Tawerny byli poza Brandem: Wsiewołod Bajkin, Borys Ewreinow, Oleg Kołodij, Aleksandr Turincew i inni. Z kręgiem współpracował dziennikarz Dmitrij Fiłosofow. Tawerna poetów utrzymywała bliski kontakt z grupą Skamandrytów. Rosjanie opublikowali w 1923 r. zbiór wierszy i opowiadań Szestero. Mały Almanach. Poezji i Prozy (Hecmepo. Мальй альманах поэзии и прозы). Dwa lata później Tawerna poetów przestała istnieć, zob.: П. Лавринец, К истории Виленского содружества поэтов, „Literatura” (2002), nr 44; I. Obłąkowska-Galanciak, Из истории русской эмиграции („Таверна поэтов” - Варшава 1921-1925), w: Literatura rosyjska na emigracji. Wspótcześni pisarze rosyjscy w Polsce. Frazeologia i frazeografia. Materiały konferencji naukowej (9-10 listopada 1995 r.), red. W. Skrunda, W. Zmarzer, Warszawa 1996, s. 77-81; В. Станиславский, Русская эмигращия в Варщаве, „Новая Польша” (2002), nr 5, s. 17-22.

47 Społeczność Literacka (Литературное содружество) istniała od 1929 do 1935 r. Pierwotnie była to sekcja literacka Związku Literatów i Dziennikarzy Rosyjskich (Союз русских писателей и журналистов). Jej spotkania odbywały się dwa razy w miesiącu, obejmując poza Brandem innych literatów: Dmitrija Fiłosofowa, Lwa Gomolickiego, Antoniego Dombrowskiego, Sonię Kindiakową, S.P. Kuncewicza, S. Wojciechowskiego. Rosyjscy pisarze i poeci zapraszali polskich kolegów - Juliana Tuwima czy Kazimierza Wierzyńskiego, zob.: Т. Исмагулова, Русская эмиграция в Польше (Владимир Бранд - поэт и воин „русской Варшавы”), w: Зарубежная Россия 1917-1939 г2.: Сборник статей, ред. В.Ю. Черняев, Санкт-Петербург 2000, s. 346-347 oraz Ł. Dryblak, Czy tylko prometeizm? Polityka państwa polskiego wobec wybranych kót emigracji rosyjskiej w latach 1926-1935, „Studia z Dziejów Rosji i Europy Środkowo-Wschodniej” 51 (2016), nr 1, s. 100.

48 Ponadto Brand współredagował i pisał w dodatkach „Za wolność!”: „Jedność. Wolna trybuna młodzieży” („Единение. Вольная трибуна молодежи”), „W swoim kącie” („В своем углу”) i „Zjednoczenie” („Объединение”). „Міесz” (Меч) był uznawany za nieoficjalny tytuł NTS. Najważniejszą rolę odgrywali w redakcji: D. Fiłosofow, W. Brand i Gieorgij Sokołow, zob.: P. Mitzner, op. cit., s. 140-141 oraz Adam R. Suławka, Prasa rosyjska i rosyjskojęzyczna o tematyce społecznej, politycznej i kulturalnej, wydawana w Warszawie (lata 1918-1939), „Rocznik Mazowiecki" (2013) nr 25, s. 149-152.

49 В. Булгаков, Словарь русских зарубежных писателей, New York 1993, s. 241; Ł. Dryblak, op. cit., s. 102-103 oraz P. Mitzner, op. cit., s. 139. 
nie zszedł z drogi konspiracji politycznej. Był w jednym czasie związanym z Bractwem Rosyjskiej Prawdy [Братством Русской Правды ${ }^{50}$, a wkrótce stał się jednym z wiodących aktywistów Narodowego Związku Nowego Pokolenia ${ }^{51}$.

Organizacja Narodowy Związek Nowego Pokolenia (Национальный Союз Нового Поколения) powstała na II Zjeździe w 1931 r. - wówczas delegaci z siedniu krajów wybrali władze z prezesem zarządu w Belgradzie Wiktorem Bajdałakowem na czele, a przewodniczącym rady z siedzibą w Paryżu księciem Siergiejem Leuchtenberskim. Nie znamy daty zainteresowania Referatu „Wschód” Oddziału II Sztabu Głównego WP „nowopokoleńcami”. Obecnie nie wiemy o początkach inicjatywy „dwójki” - czy polski wywiad doprowadził do spotkania Fiłosofowa z Würglerem, czy było na odwrót? Pewne jest, że mogło się to odbywać tylko za wiedzą i przyzwoleniem oficerów Oddziału II.

Brand wstąpił na początku lat trzydziestych do NTS, będąc do 1935 r. liderem polskiego oddziału organizacji. Współpracował z Georgijem Rozenschild-Paulinem i Aleksandrem Würglerem. Zorganizował szkołę dywersyjną pod Warszawą i grupę operacyjną NTS we współpracy z II Oddziałem Sztabu Głównego WP, który zapewniał wsparcie oraz pomoc Brandowi i NTS. Jedynie Michaił Brżestowskij wspominał o swym wyjeździe latem 1939 r. z Niemiec do Polski. Tu odbył kurs dywersyjny na polecenie Wiktora Bajdałakowa. Szkolenie, trwające osiem tygodni (czerwieclipiec) obejmowało przygotowanie do „sowieckich” zasad życia codziennego i terminologii stosowanej w rozmowach ulicznych, naukę struktur partii bolszewickiej

50 Bractwo Rosyjskiej Prawdy (Братство Русской Правды - БРП/ВRP) zostało założone w $1921 \mathrm{r}$. jako głęboko zakonspirowana bojowa organizacja monarchistyczna. Najwyższą władzą wykonawczą organizacji było Centrum Braterskie - Najwyższy Krąg (Братский Центр - Верховный Круг), emigracyjna rosyjska organizacja antysowiecka o charakterze monarchistycznym, działająca w latach dwudziestych i początku lat trzydziestych XX w. Inicjatorem jej utworzenia był prawdopodobnie poeta i adwokat Siergiej Sokołow. Wśród założycieli znaleźli się też pisarz Aleksandr Amfiteatrow oraz biskup prawosławny Hermogen, a przedstawiciele rosyjskiej generalicji i arystokracji (generałowie Piotr Krasnow, Piotr Wrangel, Dmitrij Chorwat oraz książę Anatolij Liwen) popierali organizację. Głównym celem BRP było zbrojne obalenie władzy bolszewickiej w Rosji. Początkowo organizacja wspierała partyzantkę i konspirację przeciw bolszewikom na Białorusi, Ukrainie, Kaukazie i Dalekim Wschodzie. W planach były działania terrorystyczne wymierzone w symbole i przedstawicieli władzy sowieckiej (np. wysadzenie mauzoleum Lenina w $1930 \mathrm{r}$. w powietrze). Organizację rozpracował agent OGPU baron A.N. Kolberg, jeden z przywódców Bractwa do września 1932 r. BRP współpracowało blisko z ROWS i NTS. Bractwo wydawało pismo „Rosyjska Prawda” (Русская правда). Sama organizacja przestała działać w 1933 r.

51 С.Л. Войцеховский, Эпизоды..., s. 393. Chronologia zmian nazewnictwa NTS: 1927 - Związek Rosyjskiej Młodzieży Narodowej (Союз русской национальной молодёжи - CPHM/SRNM); 1929 - Narodowy Związek Młodzieży Rosyjskiej za granicą (Национальный союз русской молодёжи за рубежом - НCPM/NSRM); 1931 - Narodowy Związek Nowego Pokolenia (Национальный союз нового поколения - НСНП/ NSNP); 1937 - Narodowo-Pracowniczego Związku Nowego Pokolenia (Национально-трудовой союз нового поколения - НTCHП/ NTSNP); 1943 - Ludowo-Pracowniczy Związek (Rosyjskich Solidarystów) Народно-трудовой союз (российских солидаристов) - HTC/NTS. 
i aparatu sowieckiego, topografii obszarów przygranicznych jak i całej geografii Sowdepii, sieci kolejowych, szyfrowania korespondencji, wykonywania fotografii, niekonwencjonalnego otwierania zamków, użycia pistoletów i rewolwerów oraz pokonywanie $60-70 \mathrm{~km} \mathrm{w}$ ramach marszów kondycyjnych. Wykładowcami byli polscy oficerowie Oddziału II SG WP oraz Gieorgij Okołowicz, Aleksandr Kołkow, Aleksandr Czuprunow oraz (prawdopodobnie) Władimir Brandt. Polski wywiad wojskowy ułatwiał przerzut przez „zieloną granicę” członków NTS do Sowietów oraz przygotowywał dla nich kopie dokumentów. Rosyjscy autorzy wspominają, że NTS prowadził skomplikowane gry z „polskim podziemiem” po 1939 r. oraz miał „kontakty z żydowskim gettem w Warszawie” ${ }^{52}$.

Wojciechowski tak wspomniał, okres, w którym przyszło działać Brandowi: „Niemcy - należy powiedzieć - nie od razu zwrócili uwagę na istnienie mniejszości narodowych w Polsce. Nie dążyli do prześladowania tych rosyjskich emigrantów, którzy w pierwszych dniach wojny wzywali do oporu wobec Niemiec. Na przykład, nie represjonowali redaktorów warszawskiego pisma «Meч»- W. W. Branda i G. G. Sokołowa" ${ }^{53}$. Brand stał się jednym z czołowych członków NTS, a podczas II wojny światowej służył w Sztabie Specjalnym Rosja (Sonderstab Russland) i Rosyjskiej Armii Wyzwoleńczej (Русская освободительная народная армия POA-ROA). Mimo to zainteresował się nim KdS Warschau.

Jesienią $1941 \mathrm{r}$. NTS rozpoczął tworzenie sieci organizacyjnej w Mińsku i Witebsku oraz centrum w Smoleńsku, gdzie Związkowi patronował burmistrz Mieńszagin. „W $1941 \mathrm{r}$. Związek, nieco zmieniwszy w tym czasie swoją nazwy, oddelegował go jak wielu innych swoich członków, na okupowane przez wojska niemieckie na terytorium Rosji [ZSRS]. W marcu następnego roku [16.03.1942], Brand zmarł na tyfus w Smoleńsku"54. Tak pisał poeta i oficer W. Brand, który jakby przewidział swój los:

52 AIPN BU, 185/340, t. 1, No. 6075/3, Опертивиная сводка No-58, Агентурно-Следственная работа, Народный Коммиссар Внутренных Дел БССР, Старшый майор ГБ, Цанава, Секретарю ЦК КП/б/ Белорусской ССР, 25 ноября 1939 г. Минск, k. 5; Т. Исмагулова, op. cit., s. 348-351; P. Mitzner, op. cit., s. 141-142; А. Окулов, В борьбе за Белую Россию. Холодная гражданская война, Москва 2013, s. 316; От Зарубежья до Москвы. Национально-Трудовой Союз (НТС) в воспоминаниях и документах 1924-2014, ред. В. Сендеров, Москва 2014, s. 23 (Борис Пушкарев, НТС в истории русского сопротивления) і s. 92-95 (Михаил Бржестовский, Свидание с родиной).

53 С.Л. Войцеховский, Эпизоды..., s. 393.

${ }^{54}$ Po rozpoczęciu wojny niemiecko-sowieckiej przerzuty ok. 250 członków NTS z GG na okupowane terytoria RFSRS rozpoczęły się w lipcu $1941 \mathrm{r}$. Tymi działaniami kierował przewodniczący polskiego oddziału NTS, Aleksandr Würgler. Emisariusze otrzymywali dokumenty podróżne, choć jechali też bez nich. W rezultacie przedarł się co piąty członek NTS w Europie (z Serbii, Bułgarii, Protektoratu Czech i Moraw, Słowacji, Francji, Belgii, Niemiec i GG). Niemcy mieli zaproponować Brandowi współpracę po zaproszeniu na al. Szucha, ale ów opuścił swój dom i wyjechał do Smoleńska, zob.: Ł. Dryblak, op. cit., s. 102-106 i 108-109 oraz P. Mitzner, op. cit., s. 141-142. 
Что ждет нас там? Восторг иль муки

В родной, неведомой стране?

Несли ей сердце, мозг и руки,

Молясь в осенней тишине...

[Co czeka nas tam? Rozkosz czy męki

W ojczystym, nieznanym kraju?

Nieśli jej serce, mózg i ręce,

Modląc się w jesiennej ciszy... $]^{55}$.

Latem 1942 r. Artur Ritter ${ }^{56}$ przypadkowo poznał rosyjskiego emigranta, inż. (płk.) Mikołaja Tumanowa ${ }^{57}$, który posiadał fenomenalną pamięć i wręcz encyklopedyczną wiedzę na temat emigracji „białorosyjskiej” nie tylko w GG, ale także w innych państwach Europy. Ritter dowiedział się od Tumanowa o istnieniu w Warszawie organizacji Oficerskogo Sobranija ${ }^{58}$, co zainteresowało NKWD-NKGB,

55 Żona poety Tatiana z domu Rudniewa, pojechała z ich synem za mężem do Smoleńska. Po jego śmierci wróciła do GG, skąd ewakuowała się i zginęła w bombardowaniu w Niemczech, zob.: W.W. Brand, Из стихов, написанных по пути в Смоленск 11.11.1941, w: Т. Исмагулова, op. cit., s. 345-352 oraz P. Mitzner, op. cit., s. 144-145.

56 Artur Ritter-Jastrzębski, ps. „Andrzej”, „Bogdan”, „Stefan”, „(Wilhelm) Tell” (ur. 12.05.1906 w Orle, zm. 7.05.1981 w Warszawie) - działacz Komunistycznej Partii Polski od 1927 r. Absolwent kursów wojskowo-politycznych Sekcji Polskiej Międzynarodówki Komunistycznej, został skierowany do Centralnego Wydziału Wojskowego KPP. Wiosną 1941 r. po przeszkoleniu został kadrowym oficerem NKWD/NKGB. Pracował dla sowieckiego wywiadu wojskowego za pośrednictwem Czesława Skonieckiego ps. „Ksiądz”, kierownika Wydziału Specjalnego KC PPR, oficjalnie podlegającemu wywiadowi Kominternu, a nieoficjalnie NKWD/NKGB. Był aktywnym członkiem PPR. Odegrał istotną rolę w wywiadzie sowieckim na obszarze Warszawy i Generalnego Gubernatorstwa. Jastrzębski infiltrował organizację „Miecz i Pług” z ramienia wywiadu sowieckiego. Brał udział we wspólnej akcji PPR-NKWD/NKGB-SD, polegającej na zawłaszczeniu Archiwum Wydziału Bezpieczeństwa Delegatury Rządu na Kraj. Spenetrował KdS Warschau, dzięki czemu uwolnił z al. Szucha w lipcu 1944 r. troję złapanych z siatki NKWD/NKGB.

57 Mikołaj Tumanow (ur. 1.04.1887 lub 5.05.1887 w Sankt Petersburgu, syn Pawła i Katarzyny z d. Kanin) w czasie wojny domowej w Rosji szef kadr armii gen. Wrangla. Do Polski trafił 15.07.1919 r. Studiował i ukończył Politechnikę w Sankt Petersburgu (1908-1913). W 1915 r. powołany do służby wojskowej, trafił do 9 . Armii jako wykładowca robót inżynieryjnych - awansował do stopnia pułkownika. Potem przebywał w Kijowie i Równem, skąd przybył do Polski, gdy WP zajęła miasto. Pracował w Dyrekcji Wodnej Ministerstwa Robót Publicznych. Ożenił się z Polką, ale rozwiódł się przed wybuchem II wojny światowej. Był inżynierem w fabryce „Pragi”. W czasie okupacji zamieszkiwał przy ul. Grzybowskiej 2, Wiejskiej $7 \mathrm{~m}$. 2, Rozbrat 34, zaś od 1944 r. w Krakowie przy ul. Bocznej 21 (ul. Szymanowskiego 21/8), a następnie w Częstochowie przy Starym Rynku, zob.: AIPN BU, 0-423/2603, Karta ewidencyjna nr B/21/53/45, 5.07.1946, k. 11; Wyciąg z teczki S.R.C., 9.02.1950, k. 14 (5.05.1887); Komunikat [z „toku wywiadu”] 1995/50, 3.04.1950, k. 17 (1.04.1887).

58 Oficerskoje Sobranije (Офицерсское собрание) - organizacja emigrantów rosyjskich w Warszawie, założona jeszcze w latach dwudziestych XX w. Sowiecki szpieg popełnił błąd w swych wspomnieniach, gdyż faktycznie wspomniana organizacja była wschodnim oddziałem Stowarzyszenia Rosyjskich Związków Wojskowych (Объединение Русских Войннских союзов - OPBC-ORWS). 
które rozkazało spenetrować organizację. Po rozlicznych „interesach handlowych" Ritterowi udało się zaprzyjaźnić z Tumanowem, któremu zaimponował znakomitą znajomością języka rosyjskiego i literatury. Tumanow był wielbicielem Lermontowa, Puszkina i innych poetów rosyjskich, grał z wirtuozerią na gitarze i „całkiem przyjemnie śpiewał”. Rosjanin nienawidził Niemców, ale Rittera uważał za wyjątek, wprowadzając go do środowiska „białych emigrantów”. Przyjaciołom przedstawiał go: „Niemiec, no rusofil”. W przypływie szczerości i pod wpływem alkoholu mówił do Rittera „Kakoj ty Niemiec, ty nasz, orłowskij”. Po pewnym czasie Tumanow zamieszkał w tej samej co Ritter kamienicy w niemieckiej dzielnicy przy ulicy Rozbrat 34/36, co pozwoliło agentowi NKWD-NKGB na częste, wręcz codzienne kontakty $\mathrm{z}$ Rosjaninem ${ }^{59}$.

Dzięki bliskiej znajomości i dyskretnej obserwacji Ritter poznał Tumanowa na tyle dobrze, że zdecydował się na zwerbowanie go do pracy dla NKWD-NKGB, uzyskując na to zgodę centrali (opisujemy arcyciekawy epizod z płk. Tumanowem w związku z tym, że Ritter-Jastrzębski był też nominalnie członkiem PPR i Gwardii Ludowej). Pod koniec 1942 r. zaprosił go do restauracji przy Krakauerstrasse czyli Krakowskim Przedmieściu, a następnie, przechodząc obok hotelu Europejskiego powiedział do Tumanowa po rosyjsku:

„Kola, twoja ojczyzna potrzebuje pomocy. Zwracam się do ciebie jako oficer wywiadu radzieckiego [NKWD-NKGB], który wie, że jesteś człowiekiem uczciwym, że nie możesz godzić się z bandyckim faszyzmem, który pustoszy twój i mój kraj. Dowolno duraka waljat!..." Tumanow zatrzymał się, znieruchomiał, chwycił mnie kurczowo za rękę, spojrzał mi w oczy nie mogąc wykrztusić słowa. Staliśmy jakąs chwilę w milczeniu, krzyżując spojrzenia. W jego oczach dostrzegłem nagle łzy. Ściskał moją dłoń i płakał. Stał przede mną człowiek sterany życiem, który do tej chwili czuł się nikomu nie potrzebny; nagle usłyszał, że ojczyzna zwraca się do niego o pomoc w trudnej chwili. Ojczyzna, którą był utracił. Po upływie kilkunastu chwil opanował się i wyrzekł cicho: „Arturze, ja nigdy nie będę komunistą, no dla ojczyzny mojej uczynię wszystko. Wszystko!” Taka była jego pierwsza reakcja. Poprosił o jeden dzień do namysłu. Wyraziłem zgodę, bo inaczej być przecież nie mogło. Doskonale rozumiałem, że powinien, że musi ochłonąć z wrażenia, że na pewno

W 1943 r. liczyła ok. 800 członków, jej prezesem był gen. Walerian Trusow (ur. 30.09.1879 w Michałkowie w guberni riazańskiej, zm. 24.12.1957 w Nowym Jorku). W okresie dwudziestolecia międzywojennego mieszkał w Lublinie, działając w rosyjskich organizacjach kombatanckich i monarchistycznych. Był naczelnikiem polskiego oddziału Rosyjskiego Związku Ogólnorosyjskiego (Русский Обще-Воинский Союз - POBC-ROWS), przemianowanego 22.10.1938 r. na ORWS, zob.: O. Beyda, Iron Cross of the Wrangel's Army. Russian Emigrants as Interpreters in the Wehrmacht, „Journal of Slavic Military Studies” 27 (2014), nr 3, s. 432 oraz В.И. Голдин, op. cit., s. 285.

59 Archiwum Dokumentacji Historycznej PRL (dalej: ADH PRL), Kolekcja Walerego Namiotkiewicza N-I/29, Nieocenzurowane wspomnienia Artura Jastrzębskiego „Życie na krawędzi”, oprac. Stanisław Majewski, b.d., k. 151-153 oraz Życie na krawędzi. Wspomnienia..., s. 87-88. Maszynopis wspomnień został opublikowany we wspomnianym wyżej zbiorze, czerpiącym zresztą tytuł od relacji Rittera-Jastrzębskiego. 
chce pobyć teraz sam, tylko sam ze swoimi myślami. Pożegnałem go i oddaliłem się. Tumanow poszedł w swoim kierunku, a w ślad za nim podążyła dyskretna obserwacja, którą zapewnił Skoniecki [Czesław Skoniecki ps. Ksiądz, kierownik Wydziału Specjalnego KC PPR, szef siatki NKWD/NKGB w Warszawie] uprzedzony o planowanym przedsięwzięciu. Ustalono, że Tumanow udał się wprost do swego mieszkania, którego nie opuszczał już do dnia następnego. Spotkaliśmy się nazajutrz. Powitał mnie inny człowiek: odmłodzony, uśmiechnięty, energiczny. „Rozważyłem twoją propozycję - przemówił - i przyjmuję. Czekam na rozkazy!"60.

Niebawem obaj utworzyli wspólne fikcyjne przedsiębiorstwo przewozowe $\mathrm{z}$ „szyldem” umożliwiającym swobodne poruszanie się po Generalnym Gubernatorstwie, jak również stworzenie pozorów, iż Tumanow ma stałe i pokaźne dochody, pozwalające na urządzanie różnych przyjęć, spotkań i libacji, na które zapraszano osoby przedstawiające wartość dla wywiadu.

Agent wywiadu, dobrze uplasowany w dużym środowisku współpracującym lub tylko sympatyzującym z wrogiem, jest niewyczerpanym źródłem cennych informacji. Takim właśnie agentem był Mikołaj Tumanow, w środowisku białej emigracji w Warszawie. Ludzie $\mathrm{z}$ tego środowiska powodowani gadulstwem, samochwalstwem, zawiściami o wpływ i stosunki - rozpowiadali o kontaktach, najróżniejszych sprawach i sprawkach. Z tej mozaiki układał się obraz interesujący dla wywiadu [NKWD-NKGB - H.K.]. [...] Kola pracował z poświęceniem. Rozpierała go radość z odzyskanej ojczyzny i duma, że może jej służyć w trudnym czasie. Bywało, że musiałem powstrzymywać jego zapędy, a nawet karcić za lekceważenie niebezpieczeństwa ${ }^{61}$.

Tak pisał po wojnie o działalności Mikołaja Tumanowa oficer SB, ppor. Wiesław Gawor w notatce na temat prowadzonego przez siebie jego wnuka, Włodzimierza: „Dziadek Tumanowa był carskim oficerem i [R]osjaninem. Uciekł z Rosji po Rewolucji Październikowej. W czasie II wojny światowej mieszkając na terenie W-wy współpracował z kontrwywiadem radzieckim [NKGB - H.K.]. Jako były «biały» oficer miał za zadanie nawiązać kontakt z grupą oficerów armii Własowa stacjonującej w W-wie"62.

Dzięki emigranckim przyjaźniom oraz odkrytym zdolnościom, Tumanow pozyskiwał pierwszorzędne źródła informacji, wykorzystując nieświadomych tego ludzi ze środowiska warszawskich Rosjan. Był mistrzem, jeśli chodzi o „wywoływanie nastroju” i „rozwiązywanie języków”. Charakter i efekty działalności Tumanowa dobrze obrazuje kolejny fragment wspomnień Rittera-Jastrzębskiego:

${ }^{60}$ ADH PRL, Kolekcja Walerego Namiotkiewicza N-I/29, Nieocenzurowane wspomnienia..., k. 156-157 oraz Życie na krawędzi. Wspomnienia..., s. 89-90.

${ }^{61}$ ADH PRL, Kolekcja Walerego Namiotkiewicza N-I/29, Nieocenzurowane wspomnienia..., k. 158-159 oraz Życie na krawędzi. Wspomnienia..., s. 90-91.

62 AIPN BU, 00 1121/4399, Notatka służbowa dot. studenta II roku Wydz. Filozofii Chrześcijańskiej Akademii Teologii Katolickiej, Włodzimierza Tumanowa, 20.03.1980, k. 25-26. 
A duszę rosyjską znał dobrze i wiedział, w jaki ton należy uderzyć, by odebrać właściwe echo. Kiedyś, pamiętam, zaprosił kozackiego [sic! - dragonów] pułkownika [Iwana - H.K.] Siewastiejewa ${ }^{63}$, który zjawił się ponury jak chmura gradowa. Początkowo zachowywał się sztywno, z dystansem i raczej milcząco, mówił bardzo zdawkowo i oszczędnie. Kola nie żałował przedniej nalewki, uderzał w struny, grając pieśni tak rzewne, starorosyjskie, że najtwardsza dusza musiała zaskamleć. W pewnej chwili zapytał gościa: „Wania, a pamiętasz tę swoją pieśń pułkową?”

I uderzył w struny, i zaśpiewał całym głosem tak, że Siewastiejew zapomniał o wszystkim, huknął się w pierś aż zadudniło, podchwycił pieśń, rozpłakał się, w końcu poszarpał na sobie koszulę na strzępy. Eskadronnaja piesnia - to pieśń pułkowa. W carskiej Rosji był taki zwyczaj, że każdy pułk miał własną pieśń.

W takich i podobnych okolicznościach dowiadywaliśmy się na przykład, że syn starego emigranta Brunnera [Mikołaj Brunner ps. „Krasnow”?] udaje się określonego dnia do Pskowa, z dużą sumą pieniędzy, skąd organizowany będzie przerzut dywersantów na tyły Armii Czerwonej. Innym razem ustaliliśmy, że Szapowałow wyjedzie w tym samym celu do Charkowa...

Jeszcze młody Brunner nie zdążył wsiąść do pociągu w Warszawie, a już Centrala w Moskwie mogła powiadomić komórkę wywiadu w Pskowie o spodziewanej wizycie o podjąć kroki w celu likwidacji emisariusza. Zdarzało się, że goście Tumanowa wyrażali przy nas zdumienie z powodu niezwykłej operatywności radzieckiego kontrwywiadu, gdyż wysyłani przez Berlin do ZSRR agenci likwidowani byli jeden po drugim $^{64}$.

Ritter wspierał swojego agenta, wyposażył go np. w zakupiony przypadkowo gobelin z wizerunkiem cara Mikołaja II, zrobiony w Żyrardowie na 300-lecie domu Romanowów. Obaj planowali także zamach na gen. Andrieja Andriejewicza Własowa, „dowódcę” Rosyjskiej Armii Wyzwoleńczej:

Któregoś dnia uzyskaliśmy informację o zamierzanym przyjeździe do Warszawy generała Własowa. Niezwłocznie przekazałem tę wiadomość do Centrali. Wraz z informacją skierowałem zapytanie, czy jeśli powstaną sprzyjające okoliczności, można przeprowadzić zamachu na Własowa. [...]

Odpowiedź nadeszła błyskawicznie; oczywiście polecono zlikwidować zdrajcę.

Mając zgodę Centrali, opracowałem szczegółowy plan akcji, wiążąc ją z przygotowywanym bankietem na cześć Własowa, organizowanym z okazji zapowiadanego przyjazdu Własowa do Warszawy. Tumanow i ja znaliśmy detale mającej się odbyć imprezy. Uzyskaliśmy też zaproszenia do wzięcia w niej udziału, co ułatwiło by nam kierowanie grupą zamachową. Dobrano odpowiednich ludzi do wykonania tego zadania.

${ }^{63}$ Iwan Siewastiejew (1876 - 23.12.1951) urodził się w Petersburgu. Służbę wojskową rozpoczął 1893 r. Skończył Twerską Szkołę Kawalerii (Тверское кавалерийское училище) w 1898. Awansował do stopnia pułkownika w 15. pułku dragonów. Na emigracji w Warszawie, a następnie w Niemczech. Zmarł 23.12.1951 w Deventer (Holandia). Żonaty, zob.: С. Волков, Офииеры Армейской Кавалерии, http://forum.vgd.ru/post/174/60778/p1760346.htm (dostęp: 17.01.2017.

${ }^{64}$ ADH PRL, Kolekcja Walerego Namiotkiewicza N-I/29, Nieocenzurowane wspomnienia..., k. 159-160 oraz Życie na krawędzi. Wspomnienia..., s. 91. 
Własow nie był to jednak kiep i dobrze wiedział, czego może się spodziewać w takim mieście jak Warszawa. Przybył bez zapowiedzi, nie spotkał się z emigrantami i zabawił w Warszawie niespełna dwie godziny, udając się w dalszą drogę, na wschód. W tych warunkach nasze zamierzenia spełzły na niczym. Po wyzwoleniu miałem z tego powodu nieprzyjemności. Okazało się, że sprawa ta oparła się o samego Stalina i od niego pochodziła decyzja; nie wykonałem zatem polecenia Stalina ${ }^{65}$.

Pułkownik Tumanow miał trzech synów, z których dwaj zginęli jako żołnierze AK podczas Powstania Warszawskiego. Wyciąg z teczki Sekcji Rejestracji Cudzoziemców (SRC) ujawnia, że 19 stycznia 1947 r. był przewodniczącym komisji wyborczej w Sandomierzu podczas sfałszowanych wyborów do Sejmu Ustawodawczego, współpracując z funkcjonariuszami UB. Długo przebywał na prowincji, gdyż „[d]o Warszawy przybył w październiku 1948 r. z miejscowości Byłwany, pow. Sandomierz i zamieszkał przy ul. Poligonowej $18 \mathrm{~m} 3$, gdzie przychodził do ww. osobnik nieznany udzielającym informacji, z którym w mieszkaniu rozmawiał w języku rosyjskim. Dnia 9 VI 1949 r. wymeldował się na ulicę Ząbkowską nr 17 m 16"66. Potem mieszkał przy ul. Dzielnej 5 m 19 w Warszawie. Uzyskał obywatelstwo polskie 22 września 1951 r. Pracował jako inspektor w Wydziale Budownictwa Ministerstwa Bezpieczeństwa Publicznego. Udzielał się w Lidze Lotniczej. Mimo to podlegał zwyczajowemu nadzorowi UB jako „wróg klasowy”, co widać w notatce kapitana UB Rudnika wspominającego, że „pułkownik armii carskiej” Tumanow „był członkiem Nacjonalistycznego Komitetu Rosyjskiego w Warszawie"67.

Te informacje trafiły do akt podczas rozpracowywania Tumanowa przez Sekcję II Wydziału [Departamentu] III MBP - dołączając pisma nr DB-928/51 z 24 marca 1953 i GMB/I/71/53 z 19 marca 1953 r. oraz doniesienia agenta ps. „Pewny” z 27 listopada 1952 r. - informował kpt. Adasiak, zastępca naczelnika Wydz. Kadr WUBP w Warszawie: „Nadmieniam, że ww. [Tumanow Mikołaj] był pracownikiem WUBP W-wa [od 15.02.1952 r.] i z dn. 31 III 53 zwolniony został z pracy. Inne materiały kompromitujące na ww. zostały przesłane do naczelnika Wydz. Ogólnego WUBP”. Podobnie błędne wnioski wyciągał [sędzia Marian?] Osowski, powątpiewający w zaangażowanie rewolucyjne carskiego oficera: „Rzekomo miał

65 ADH PRL, Kolekcja Walerego Namiotkiewicza N-I/29, Nieocenzurowane wspomnienia..., k. 161162 oraz Życie na krawędzi. Wspomnienia..., s. 92-93 (tutaj mowa o „poleceniu dowództwa" - tak działała cenzura za Gierka - sic!).

66 AIPN BU, 0-423/2603, Notatka służbowa dot. opracowania akt archiwalnych nr 1465/IV, 14.11.1949, k. 1; Komenda Milicji Obywatelskiej m. st. Warszawy, Szef Sekcja Rejestracji Cudzoziemców Komendy MO st. Warszawy do Ewidencji Ludności m. st. Warszawy, L. dz. 1761-Ref 49, 22.06.1950, k. 9-10; AIPN BU, 0-423/2603, Karta ewidencyjna nr B/21/53/45, 5.07.1946, k. 11; Wyciąg z teczki S.R.C., 9.02.1950, k. 14.

67 AIPN BU, 0-423/2603, Komunikat [z „toku wywiadu”] 1995/50, 3.04.1950, k. 17; Notatka informacyjna płk. „D”, 31.10.1951, k. 21; Informacja Dep. II MBP na rzecz Wydz. II Dep. III MBP nr BD-036/3.I/51 nr 10999/2/51, 31.10.1951, k. 22-23. 
być w podziemiu wraz z obecnym naczelnym redaktorem «Chłopskiej Drogi» z Czesławem Skonieckim i płk. Jastrzębskim, obecnym szefem W.U.B.P. w Lublinie, ma również posiadać krzyż partyzancki"68.

Rzeczywiście władze PRL odznaczyły go Krzyżem Partyzanckim ${ }^{69}$. Mikołaj Tumanow zmarł 17 października 1960 r. i został pochowany na Cmentarzu Wojskowym na Powązkach (kwatera: II B 28, rząd: 10, grób: 12), niedaleko jednego ze swoich synów, tego niespalonego w szpitalu na Ochocie ${ }^{70}$.

\section{Rosjanie po stronie Polaków w Powstaniu Warszawskim}

Ten mało znany epizod historii Powstania Warszawskiego obejmuje kilka osób walczących i zaangażowanych po stronie powstańców. Dwie pierwsze są związane z osobą płk. Mikołaja Tumanowa - jego synowie (i Janiny z domu Gorliwej), którzy zginęli podczas sierpniowo-październikowej hekatomby Warszawy. Pierwszym z nich był Włodzimierz (ur. 17.11.1924, zm. 11.08.1944). Był żołnierzem AK i walczył w stopniu strzelca pod pseudonimem „Książę”, służąc w IV Obwodzie Warszawskiego Okręgu Armii Krajowej, ale nie jest znany jego przydział służbowy ${ }^{71}$.

68 AIPN BU, 0-423/2603, Wojewódzki Urząd Bezpieczeństwa Państwowego, L. dz. PE-2486/53, 2.04.1953, k. 24-27; Dyrektor Departamentu III MBP, płk Andrzejewski do Naczelnika Wydziału III UBP, 24.03.1953, k. 29; V-Dyrektor Departamentu X MBP, ppłk Światło do Dyrektora Departamentu III MBP, płk Czaplickiego, 19.03.1953, k. 30.

${ }^{69}$ Krzyż Partyzancki ustanowiła 26.10.1945 r. mocą dekretu Rada Ministrów Tymczasowego Rządu Jedności Narodowej, zatwierdzonego przez Prezydium Krajowej Rady Narodowej. Polscy komuniści ustanowili to odznaczenie „w celu upamiętnienia bohaterskiej walki zbrojnej żołnierzy oddziałów partyzanckich z hitlerowskim okupantem o Niepodległość, Wolność i Demokrację oraz celem nagrodzenia bojowych zasług w tej walce”. Krzyż Partyzancki zajmował w kolejności porządku odznaczeń PRL miejsce po Krzyżu Walecznych.

70 AIPN BU, 0-423/2603, Raport o zarejestrowaniu w ewidencji ogólno-informacyjnej do zastępcy naczelnika Wydz. II-go, kpt Branda, 12.05.1955, k. 47 i http://www.cmentarzekomunalne.com. $\mathrm{pl} / \mathrm{mapa} / \mathrm{mapa} \cdot \mathrm{php}$ ?cment=PWZKI\&rzad=10\&kwatera $=I I \% 20 \mathrm{~B} \% 2028 \&$ grob $=12 \&$ dane $=+$ imie$=+$ nazwisko $=$ Tumanow + check_nazwisko $=$ on + check_ur $=+$ rok $=1800+$ miesiac $=1+$ dzien $=1+$ rok $2=2015+$ miesiac $2=8+$ dzien $2=2+$ check_zg $=+$ rok_zg1 $1=1800+$ miesiac_zg1 $=1+$ dzien_zg1 $=1+$ rok_ zg2=2015+miesiac_zg2=8+dzien_zg2=2+cmentarz=\#kotwica (dostęp: 17.01.2017).

71 Obwód IV Ochota AK - kryptonimy: „Osiemnastka”, „18” (w ramach SZP), a później w ramach ZWZ/AK „44”, „XXIV” (od 15.06.1944), „IV” (od 9.08.1944) - był strukturą organizacyjną okręgu warszawskiego Armii Krajowej działającą w okresie okupacji niemieckiej w Polsce. W przeddzień wybuchu powstania stan liczbowy obwodu osiągnął ok. 1500-1800 żołnierzy i oficerów. W jego skład wchodziła też Wojskowa Służba Kobiet, licząca ok. 400 konspiratorek w oddziałach sanitarnych i łączności. Dowódcą IV Obwodu Ochota AK był ppłk Mieczysław Kazimierz Sokołowski ps. „Grzymała”, „Ojciec”, „Pomian”, „Unikat”. Pozostałe na Ochocie oddziały przeszły do obrony, tworząc dwie reduty: „Wawelską” - w czworoboku bloków przy ulicach: Wawelskiej, Pługa, Mianowskiego i Uniwersyteckiej - pod dowództwem ppor. Jerzego Gołembiewskiego „Stacha”; „Kaliską” - w zespole budynków Monopolu Tytoniowego i przyległych domów - pod dowództwem por. Andrzeja Chyczewskiego „Gustawa”. 
Ten obwód osłaniał miasto od strony południowo-zachodniej, granicząc z Mokotowem, Śródmieściem i Wolą. Opanowanie Ochoty przez powstańców zamykało Niemcom dostęp do najkrótszych arterii transportowych, prowadzących od południowego-zachodu i południa przez centrum miasta ku mostom na Wiśle. To utrudniało znacząco zaopatrywanie oddziałów Armii Wschodniej (Ostheer), walczących z sowiecką 2. Armią Pancerną. Powstańcom nie udało się zdobyć silnie ufortyfikowanych niemieckich koszar niemieckich w Domu Akademickim przy placu Narutowicza, w budynku Dyrekcji Lasów Państwowych przy ul. Wawelskiej 56 oraz przy ul. Tarczyńskiej 8. Przyczyną było słabe uzbrojenie oraz mała liczebność oddziałów powstańczych płk. „Grzymały”. W chwili koncentracji stawiło się zaledwie $50-60 \%$ stanu w plutonach liniowych na wyznaczonych punktach. Natarcia na wyznaczone cele, rozpoczęte 1 sierpnia o godz. 17.00, błyskawicznie załamywały się po zdziesiątkowaniu atakujących. Powstańcom, mimo brawury i męstwa, nie udało się zdobyć żadnego z kluczowych obiektów. Po tych niepowodzeniach dowódca zgromadził przetrzebione oddziały w kwadracie ulic Asnyka, Niemcewicza, Grójeckiej i Filtrowej, gdzie zorganizował obronę. Po odprawie sztabowej ppłk Sokołowski zdecydował o ewakuacji ocalałych sił do lasów chojnowskich i sękocińskich, z myślą ich dozbrojenia i ponownym włączeniu do walk.

Już nocą z 1 na 2 sierpnia sprzed kamienicy przy ul. Niemcewicza 7/9 wyruszyła kolumna ponad 500 osób marszem ubezpieczonym, z których 50 powstańców było dobrze uzbrojonych, ale reszta bezbronna. Ponieśli duże straty pod Pęcicami. $\mathrm{Na}$ Ochocie pozostały trzy oddziały, do których nie dotarła wiadomość o koncentracji i wymarszu. Wśród nich znajdował się Włodzimierz Tumanow, wchodzący najprawdopodobniej w skład plutonu ppor. Jerzego Gołembiewskiego ps. „Stach”.

Właśnie ci powstańcy zorganizowali obronę Reduty Wawelskiej, utworzonej przez: Dom Spółdzielni Inżynierów byłego Ministerstwa Kolei Żelaznych (Wawelska 62 róg Mianowskiego 15 i Pługa) oraz Dom Spółdzielni Pracowników Ministerstwa Kolei Żelaznych (Wawelska 60 róg Uniwersytecka 1 róg Mianowskiego 13). Po upadku sąsiedniej Reduty Kaliskiej (kwartał ulic Kopińska, Białobrzeska, Joteyki, Kaliska) tego drugiego bastionu powstańczego bronił skutecznie pluton ppor. „Stacha” przez prawie tydzień. AK-owcom udało się krótkotrwale wyeliminować z walk jeden z niemieckich niszczycieli czołgów Jagdpanzer 38 (t) Hetzer z 1. kompanii Armee Panzerjäger Abteilung 743, wspierających działania pułku zbiorczego RONA. Podczas tych walk 6 sierpnia Włodzimierz Tumanow został ciężko ranny w budynku przy ul. Wawelskiej. Powstaniec rosyjskiego pochodzenia został przeniesiony do szpitala, który mieścił się w piwnicy przy ul. Mianowskiego 15.

Tymczasem Rosjanie z RONA przypuścili 11 sierpnia ostateczny szturm, który zmusił obrońców do ewakuacji kanałami (ponad $80 \mathrm{z}$ nich przedostało się do Śródmieścia, wchodząc w skład batalionu AK „Golski”). Na miejscu pozostało 14 sanitariuszek i 3 lekarki, opiekujące się 20 ciężko rannymi. Mimo wywieszenia białej flagi budynki były nadal ostrzeliwane. O zmroku żołnierze RONA wdarli się na Wawelską, zamordowali w tym rejonie ponad 80 osób - rannych powstańców 
oraz mieszkańców kamienicy podejrzewanych o walkę. Ofiarami byli m.in. ks. prof. Jan Salamucha (kapelan Obwodu AK „Ochota”), ale też syn płk. Tumanowa ${ }^{72}$. Oto jak to opisał kronikarz powstańczej Ochoty:

Dopiero około godz. 19.00 otoczyła kordonem bloki kompania SS-manów [żołnierzy SS RONA] z Akademii Nauk Politycznych przy Wawelskiej. Napastnicy przez dłuższy czas nie mogli się dostać do wnętrza bloków zasypanych ziemią aż po piętro. Spotęgowało to ich wściekłość. Rozbili wreszcie okienko nad drzwiami klatki schodowej od ul. Pługa. Zepchnąwszy część nasypu umacniającego drzwi, wdarli się do środka - na przedzie zgraja oprawców i rabusiów [żołnierzy] z pułku RONA, za nimi niemiecki oficer. [...] Wpadłszy do piwnicy, gdzie mieścił się szpital, tam także wymordowali wszystkich rannych, wśród nich inż. Erazma Maciejewskiego, Jana Łempickiego, Jarosława Skrzyńskiego, dwóch kilkunastoletnich chłopców, rannych od wybuchu tego samego pocisku - Włodzimierza Tumanowa i Janusza Kwiatkowskiego; konającego, wpółprzytomnego powstańca „Lwa” dobili na noszach. Zgarnęli potem jakieś drewno i papiery, a następnie podpalili szpitalik razem ze zwłokami ${ }^{73}$.

Strzelec „Książę” został upamiętniony w Muzeum Powstania Warszawskiego cegiełką w Murze Pamięci: kolumna 135, pozycja $63^{74}$.

Jego brat Eugeniusz (ur. 9.08.1926 lub - według drugiej wersji - 31.12.1926 zm. 18.09.1944), walczył w stopniu strzelca pod pseudonimem „Tur”. Był przydzielony do III Obwodu Wola Warszawskiego Okręgu AK, służąc w oddziale osłony Komendanta III Obwodu - 300. plutonie osłonowym (dotychczasowym Oddziale Dywersji Bojowej 16) pod dowództwem ppor. rez. piech. Stefana Mrozowskiego ps. „Pik”. Po zranieniu go 4 sierpnia, zastąpił go plut. podch./ppor. Janusz Przedborski ps. „Ludwik”75.

${ }^{72}$ M. Motyl, S. Rutkowski, Rejestr miejsc i faktów zbrodni popelnionych przez okupanta hitlerowskiego. Powstanie Warszawskie 1 VIII - 2 X 1944, Warszawa 1994, s. 92 (ul. Mianowskiego 15 - wspominają o 9 rannych powstańcach zamordowanych przez „hitlerowców”), s. 170-171 (ul. Wawelska 60 - zamordowanych 80 warszawiaków, w tym Włodzimierz Tumanow „Książę”); Д. Жуков, И. Ковтун, 29-я гренадерская дивизия СС „Каминский”, Москва 2009, s. 172-175 oraz http:// www.1944.pl/historia/powstancze-biogramy/Wlodzimierz_Tumanow (dostęp: 17.01.2017).

${ }^{73}$ J.K. Wroniszewski, Ochota - Okęcie. Przewodnik historyczny po miejscach walk i pamięci z lat 1939-1944, Warszawa 2002, s. 111-112.

${ }^{74}$ Przy eksploracji portalu internetowego Cmentarzy Komunalnych w Warszawie, a dokładnie Cmentarza Wojskowego na Powązkach okazało się, że Mikołaj Tumanow miał trzech synów, w tym najstarszego - Jerzego, który urodził się 2.09.1922 r., a umarł 25.07.1979 r. Ponadto został z nimi pochowany prawdopodobnie syn Jerzego, Włodek Tumanow (1956-2003), zmarły w Sztokholmie, zob.: http://www.cmentarzekomunalne.com.pl/mapa/mapa.php?cment=PWZKI\&rzad $=11 \&$ kwatera $=\mathrm{A} \% 2027 \& g r o b=27 \&$ dane $=+$ imie $=+$ nazwisko $=$ tumanow + check $\_$nazwi sko $=$ on + check_ur $=+$ rok $=1800+$ miesiac $=1+$ dzien $=1+$ rok $2=2015+$ miesiac $2=8+$ dzien $2=2+$ ch eck_zg=+rok_zg1=1800+miesiac_zg1=1+dzien_zg1=1+rok_zg2=2015+miesiac_zg2=8+dzien_ zg2=2+cmentarz=\#kotwica (dostęp: 17.01.2017).

75 Obwód III Wola AK - kryptonimy: „Szesnastka”, „16” (w ramach SZP), a w ramach ZWZ/ AK „43”, „XXIII” (od 15.06.1944), „III” (od 9.08.1944) - był strukturą organizacyjną okręgu warszawskiego Armii Krajowej działającą w okresie okupacji niemieckiej w Polsce w większej 
Po tygodniu walk o Wolę 300. pluton wycofał się na Stare Miasto, walcząc w Grupie „Północ”. Po upadku tej dzielnicy Eugeniusz Tumanow przeszedł kanałami na Żoliborz z macierzystym oddziałem. Tu walczył w zgrupowaniu „Żaglowiec” - kompania „Żaba”, 208. pluton ppor Edwarda Bonarowskiego ps. „Ostromir”, liczącym 15 września blisko 100 żołnierzy. Młodszy z braci Tumanow zaprzyjaźnił się z żoliborzakiem Jerzym Moździńskim ps. „Boruta”, służąc razem z nim w kilkuosobowej grupie młodzieżowej ${ }^{76}$.

Tak zapamiętali śmierć Rosjanina koledzy z powstańczego bastionu - gmachu V Państwowego Liceum i Gimnazjum im. Księcia Józefa Poniatowskiego, tzw. „Poniatówki” przy ulicy Lisa Kuli 16:

Dopiero w I dekadzie września - pierwsza strata i to jedyna w swoim rodzaju. Dokonujący ostatniego obchodu posterunków nad ranem, plut. „Fab” [Fabian Rafalski - H.K.] z trudem przedostał się przez gruzy zdemolowanej frontowej klatki schodowej na półpiętro, gdzie miał stać na posterunku strz. „Tur”. Znalazł go leżącego na półpiętrze w takiej pozycji, że przełamanym kręgosłupem był oparty o pionowy pręt poręczy schodowej, głową na stopniach kondygnacji wyższej, nogami - na niższej. Poza tym żadnych innych obrażeń ciała - nawet śladów krwi. To podmuch pocisku pozbawił go życia. „Tur” pierwszy zdekompletował grupę młodzieżową. Na „Poniatówce” odbył się jego pogrzeb. (Nie jestem pewny czy „Tur” był pierwszym poległym czy Maculewicz?).

W stolarskich warsztatach szkolnych, mieszczących się na podwórzu, partyzanci zrobili mu trumnę; plut. „Janek” Dziemianko, który praktycznie pełnił rolę szefa kompanii, umył mu twarz: „bo nie godzi się, żeby żołnierz poszedł na tamten świat brudny”, wyjął z jego kieszeni dokumenty i przepustkę partyzancką, dołączył do tego „akt zgonu” z podaniem daty śmierci - wszystko to włożył do butelki od piwa z gumowym zaciskiem. I butelkę tę włożył do trumny przy lewej nodze. Przy prawym boku nieboszczyka nie należy nic wkładać, bo gdy będzie meldował „tam” swoje przybycie, to musi zasalutować - prawa ręka żołnierza musi być więc wolna. Tak przygotowywał „Janek” Dziemianko żołnierzy na tamten świat wielokrotnie już w Puszczy, tak i teraz w podobny sposób będzie postępował do końca września. Następnie trumna zostanie przeniesiona do świetlicy szkolnej, zamienionej w kaplicę. W kaplicy tej kapelan 21. pp, [kpt.] ks. Stefan Sydry odprawiał co niedzielę cichą mszę św. Teraz ksiądz Sydry ubrany w czarny ornat odprawiał mszę żałobną, a koledzy będą w milczeniu patrzeć na otwartą trumnę, po czym zamkną ją i przeniosą na skraj boiska szkolnego do wykopanego tam grobu ${ }^{77}$.

części dzielnicy Wola. Oddziały wojskowe obwodu wzięły udział w Powstaniu Warszawskim. Komendantem obwodu był od kwietnia 1943 r. ppłk Jan Tarnowski ps. „Lelek”, „Waligóra”.

76 E. Bonarowski „Ostromir”, Burza nad Dworcem Gdańskim. W bój bez broni, Warszawa-Kraków 2014, s. 174 i 178 („Panie Edwardzie niech pan zajmie się... Niech się pan zaopiekuje Jerzykiem jak młodszym bratem, tak pana proszę. Niech go pan trzyma przy sobie. On taki młody nieobliczalny. Niech pan go trzyma przy sobie. Od tej chwili «Boruta» - taki miał pseudonim. Będzie ze mną 60 dni. Pożegnanie z matką syna odchodzącego na wojnę", ibidem, s. 31); Z. Puchalski, Walki powstańcze ma Woli (1-11 VIII 1944), „Rocznik Warszawski” 10, 1971, red. B. Grochulska, S. Herbst, J. Kazimierski, s. 215 oraz http://www.1944.pl/historia/powstancze-biogramy/ Wlodzimierz_Tumanow (dostęp: 17.01.2017).

77 E. Bonarowski, op. cit., s. 192-193. 
Eugeniusz Tumanow ps. „Tur” poległ 18 września 1944 r. Matka jego przyjaciela, Jerzego Moździńskiego, Hanna odnalazła w lipcu 1945 r. groby obu. Samodzielnie przeprowadziła ich ekshumację i pochowała razem na cmentarzu wojskowym na Powązkach. W mogile Eugeniusz Tumanow (kwatera A 27, 11 rząd, 27 grób) został pochowany z bratem, Jerzym i bratankiem Włodzimierzem. Krewni Tumanowa odnaleźli jego grób dopiero w latach 50. XX w. Pamięci „Tura” jest poświęcona cegiełka w murze pamięci Muzeum Powstania Warszawskiego: kolumna 135 , pozycja $62^{78}$.

O trzecim synu Mikołaja, Jerzym, pisał w notatce służbowej inspektor Wydziału IV, ppor. Wiesław Gawor, który był jednocześnie oficerem prowadzącym TW Bernard czyli wnuka Mikołaja Tumanowa, Włodzimierza, urodzonego 10 września 1956 r. w Warszawie, a zmarłego w 2003 w Sztokholmie:

Ojciec, Tumanow Jerzy zmarł w 1979 r. W 1939 wstąpił do ZWZ i jeszcze w tym samym roku był aresztowany przez [G]estapo. Po pobycie w Alei Szucha i na Pawiaku trafił do Oświęcimia [KZL Auschwitz], następnie do [KZL] Gross-Rozen [Rosen] i [KZL] Oranienburg, skąd zbiegł w lutym 1945 r. Od 1946 r. był członkiem ORMO i należał do PPR. W 1948 r. został skazany na 25 lat więzienia, przesiedział 5 i pół roku. Po zwolnieniu został rehabilitowany. Pracował w branży hotelarskiej w charakterze zaopatrzeniowca. Był członkiem ZBOWiD i od 1978 r. przebywał na rencie kombatanckiej ${ }^{79}$.

Skądinąd wspomniany wcześniej duchowny prawosławny, magister teologii, Aleksander Panin, był również ofiarą Powstania Warszawskiego. Niemcy zamordowali 1 sierpnia 1944 r. tego 38-letniego Rosjanina na tyłach cerkwi przy ul. Cyryla i Metodego 2 wraz z 17 innymi mężczyznami (Rosjanami, Białorusinami, Ukraińcami i Polakami) $^{80}$.

Rosjanki, które można stawiać za wzór Polakom, były związane z powstańczymi służbami sanitarnymi. Przede wszystkim była to Nadzieja Drucka O’Brien de Lacy (ur. 17 stycznia 1898 Warszawa, zm. 29 sierpnia 1986 Warszawa). Rodzicami byli generał, profesor Wojskowej Akademii Prawa Siergiej Drucki (który należał do rodziny książęcej Druckich) i Maria z Safonowiczów. Rodzina wyjechała w 1902 r. do Sankt Petersburga. Nadzieja w 1914 r. ukończyła Instytut Szlachetnie Urodzonych Panien, tzw. Instytut Smolny (Смольный институт). Ро I pierwszej wojnie światowej przeniosła się do Moskwy wraz z rodziną. Ukończyła tam kursy

${ }^{78}$ http://www.1944.pl/historia/powstancze-biogramy/Eugeniusz_Tumanow (dostęp: 17.01.2017); http://www.cmentarzekomunalne.com.pl/mapa/mapa.php?cment=PWZKI\&rzad=11\&kwate$\mathrm{ra}=\mathrm{A} \% 2027 \& g r o b=27 \&$ dane $=+$ imie $=+$ nazwisko $=$ tumanow + check_nazwisko $=$ on + check_ur $=+$ rok $=1800+$ miesiac $=1+$ dzien $=1+$ rok2 $=2015+$ miesiac2 $=8+$ dzien $2=2+$ check_zg $=+$ rok_zg1 $1=1800+$ miesiac_zg1 $1=1+$ dzien_zg1 $1=1+$ rok_zg2 $=2015+$ miesiac_zg2 $=8+$ dzien_zg2 $=2+$ cmentarz=\#kotwica (dostęp: 17.01.2017) oraz http://nieobecni.com.pl/index.php?s=grob\&id=144277 (dostęp: 17.01.2017)

79 AIPN BU, 00 1121/4399, Notatka służbowa dot. studenta II roku Wydz. Filozofii Chrześcijańskiej Akademii Teologii Katolickiej, Włodzimierza Tumanowa [TW Bernard], 20.03.1980, k. 25.

${ }^{80}$ M. Motyl, S. Rutkowski, op. cit., s. 28-29. 
medyczne i jako pielęgniarka Czerwonego Krzyża udała się na front. Tam spotkała się z Polakiem irlandzkiego pochodzenia Maurycym O’Brien de Lacy. Po zaręczynach z nim, wyszła za mąż w sierpniu 1918 r. w Moskwie. Potem udało się im wyjechać do Polski do jego rodzinnego majątku we wsi Augustówka, gdzie mieszkali do $1939 \mathrm{r}$.

Nadzieja Drucka O’Brien de Lacy zajmowała się w działalnością charytatywną i literacką. Stała się wiceprezeską lokalnego oddziału Polskiego Czerwonego Krzyża, wiceprezeską Koła Ziemianek i przewodniczącą Stowarzyszenia Miłośników Literatury i Sztuki im. Elizy Orzeszkowej w Grodnie. Na jej zaproszenie przyjeżdżali do Grodna znani pisarze: Maria Dąbrowska, Zofia Nałkowska, Julian Tuwim, Jan Parandowski, Juliusz Kaden-Bandrowski czy Stanisław Witkiewicz. Zofia Nałkowska zapisała pod datą 23 października 1929 roku w swoich Dziennikach: „Te cztery dni - poza obchodem i spędziłam w owym Augustówku jako gość państwa O’Brien de Lacy na skutek wielokrotnych zaproszeń, było mi tam tak dobrze, jak wcale nie oczekiwałam. Jesień słoneczna, liście żółte i czerwone za oknem, urok tamtejszej przyrody. Jazdy samochodem, który prowadzi pan O’Brien de Lacy taki miły, równy, łagodny”. Nadzieja Drucka O’Brien de Lacy w 1930 r. wstąpiła do polskiego Pen-Clubu. Co roku organizowała z mężem letnie obozy dla niezamożnych mieszkańców Grodna. Podtrzymywała kontakty z przedstawicielami rosyjskiej emigracji w Polsce ${ }^{81}$. W chwili wybuchu II wojny światowej jej mąż pozostał w Grodnie, biorąc udział w obronie miasta, zaś ona z córkami Gabrielą i Ireną znalazła schronienie w Spuszy, majątku Sapiehów, by później połączyć się z mężem na Litwie. Rodzina zatrzymała się w Liberyszkach, dobrach Benedykta Karpia, przyjaciela męża Maurycego z młodości.

W 1941 r. przez zieloną granicę przedostali się do Generalnego Gubernatorstwa, do Warszawy, gdzie przetrwali okupację. Nadzieja Drucka uczyła języków obcych. Brała udział w tajnym nauczaniu. Jak wspominała: „Istniało szkolnictwo tajne i oficjalne zawodowe, które również prowadziło nielegalne przedmioty, jak historia, geografia i literatura polska. Gaj poszła do szkoły handlowej na Nowogrodzkiej. Irena zaczęła pracować jako kelnerka w jakimś klubie. Niektórzy znajomi Rosjanie i Gruzini sugerowali, bym się zapisała do Komitetu Rosyjskiego, co chroniłoby od łapanek i dawałoby mi różne przywileje" 82 .

A w opracowaniu swego autorstwa Nadzieja Drucka dodawała szczegóły o „tajnych kompletach":

Warszawę podzielono początkowo na pięć rejonów, następnie na trzynaście. Na czele rejonu stał zarząd, składający się z trzech osób i zajmujący się sprawami tajnego nauczania, samopomocy koleżeńskiej oraz walki cywilnej i wojskowej. Jeden rejon obejmował przeciętnie dziesięć szkół; w każdej z nich grono nauczycielskie wybierało spośród siebie

81 Z. Nałkowska, Dzienniki, t. 3: 1918-1929, Warszawa 1980, s. 180-181; J. Sypuła-Gliwa, Dzikie gęsi z Zielonej Wyspy, „Echa Polesia” 4 (2008), nr 20, s. 69.

82 N. Drucka, Trzy czwarte... Wspomnienia, Łomianki 2011, s. 140. 
łącznika między szkołą a zarządem rejonu. [...] Programy nauczania były jednolite, oparte na programach przedwojennych z małymi odchyleniami w stronę demokratyzacji. Mimo wzrastającego terroru nastrój był nieustępliwy i patriotyczny. Do tajnego nauczania na szczeblu podstawowym doszły wkrótce spontaniczne i szybko rozpowszechniające się komplety na poziomie szkoły średniej; TON [Tajna Organizacja Nauczycielska] i inne konspiracyjne organizacje oświatowe zajęły się też tą akcją ustalając zasady, na których uczenie powinno się odbywać ${ }^{83}$.

Jak pisała Drucka w innym miejscu: „W ostatnich latach liczba uczniów szkół powszechnych w samej tylko Warszawie wynosiła 68 000, z czego 12000 objętych było tajnym nauczaniem w zakresie przedmiotów ojczystych w klasach V-VII i III gimnazjum. Na wszystkich szczeblach szkoły średniej korzystało zaś wówczas z tajnej oświaty - mowa jest dalej tylko o Warszawie - ok. 24000 młodzieży" ${ }^{4}$.

Znakomite są impresje żony i matki na temat przemiany rodziny w okupowanej przez Niemców Warszawie:

Wiedziałam już, że Maurycy należy do tajnej organizacji, chociaż nie mówi o tym, wkrótce i ja za pośrednictwem porucznika Pawła Kadena-Bandrowskiego weszłam do Sanitariatu Czerwonego Krzyża AK, ukrywając to przed mężem i dziećmi. [...] Przypuszczałam, że moja starsza córka Irena, która już pracowała w jakiejś firmie kosmetycznej, należy do organizacji, bo gdzieś znikała po południu i wracała pięć minut po zapadnięciu godziny policyjnej, przyprawiając mnie o bicie serca. Nie pytałam o nic jej ani męża. Dyskrecja w przedziwny sposób obowiązywała nawet w rodzinie. Czy to ze względu na bezpieczeństwo, czy ze zwykłej delikatności. Dopiero na kilka miesięcy przed powstaniem „ujawniliśmy się", nie kryjąc się już ze swoją trwającą od kilku lat działalnością

- zapisała we wspomnieniach księżna ${ }^{85}$.

W czasie Powstania Warszawskiego Nadzieja Drucka służyła pod pseudonimem „Literat” w Pomocy Żołnierzowi ${ }^{86}$ oraz w Sanitariacie Okręgu Warszawskiego AK.

Nie mogąc się przedostać na swój punkt w okolicy placu Narutowicza, zgłosiłam się na Powiślu (którego część południowa zwana jest w literaturze naukowej powstania Czerniakowem) do dowództwa V Zgrupowania, gdzie zastałam trzy osoby znane mi

${ }^{83}$ N. Drucka, Szkoła $w$ podziemiu. Z dziejów polskiego tajnego nauczania w latach okupacji hitlerowskiej, Warszawa 1973, s. 49-50.

${ }^{84}$ Ibidem, s. 60 oraz http://www.1944.pl/historia/powstancze-biogramy/Nadzieja_OBrien_De_Lacy (dostęp: 17.01.2017).

85 Poziom tej niezwykłej osoby podkreślają słowa: „Zawsze uważałam, że rolą kobiety na świecie jest nie zabijać, lecz dawać życie i łagodzić cierpienie. W swoim czasie, jeszcze w Rosji, napisałam artykuł, wydrukowany w gazecie redagowanej przez mojego ojca, w którym wypowiedziałam się przeciw kobiecym batalionom", zob.: N. Drucka, Trzy czwarte..., s. 141 i 147.

86 Pomoc Żołnierzowi (PŻ) - organizacja kobieca założona w marcu 1942 r. początkowo jako referat, a następnie samodzielny podwydział w strukturze Biura Informacji i Propagandy Komendy Głównej AK. PŻ ściśle współpracowała z Wojskową Służbą Kobiet. Celem tej organizacji była opieka nad żołnierzami AK. Potocznie jej członkinie były nazywane „peżetkami”. 
z czasów przedwojennych: kapitana Kryskę [Zygmunt Netzer], porucznika Siekierę [Roman Rożałowski] i porucznika Jelenia - inspektora szkolnego z Grodna. Mąż poszedł jak co dzień do pracy. [...] A my z Gają, zabierając środki opatrunkowe, poszłyśmy na róg Wilanowskiej i Okrąg, gdzie mieścił się sztab Zgrupowania. [...] Gaja, jako niewykwalifikowana została siostrą gospodarczą. To była udręka, gdy ona w towarzystwie dwóch-trzech panów szła do Społem z koszami po żywność, a Niemcy dobrze wypatrzywszy ten punkt, rozpoczęli bombardowanie całej okolicy ${ }^{87}$.

W czasie Powstania Warszawskiego była pielęgniarką Szpitala Polowego nr 3 Zgrupowania „Kryska” przy ul. Okrąg 2/4 (od 8 sierpnia do 19 września), a potem przy ul. Wilanowskiej 18/20, a następnie ul. Wilanowskiej 1, 3, 5 (od 19 do 23 września) na Górnym Czerniakowie. Komendantką szpitala była dr Irena Semadeni-Konopacka, która tak opisywała finał powstańczej służby: „Po kolei podchodziły do mnie wszystkie osoby, z którymi przez te dwa miesiące współpracowałam, żegnały się i chętnie lub mniej chętnie odchodziły. [...] Słyszałam jeszcze wiele wystrzałów i przypuszczam, że rozstrzeliwali wówczas ludność, która stała na podwórzu"88. U boku Nadziei Druckiej pracowała jej 25-letnia córka Irena. Jako sanitariuszka, peżetka, uczestniczyła w Powstaniu Warszawskim pod pseudonimem „Gaja”89. Ich krewna, Margaret O’Brien, znalazła się na Ochocie w domu przy Spiskiej, który stał się miejscem noclegu dla żołnierzy RONA:

Na podwórku koczowali Własowcy [właściwie: żołnierze pułku RONA], to był ich szlak wypadowy: $\mathrm{z}$ terenów przy dworcu na Grójecką. Chodzili tam i z powrotem przez naszą bramę. Wieczorem sprowadzali sobie jakieś kobiety [...] nie chciałam ani widzieć, ani słyszeć, co tam się dzieje. [...] Na schodach spali pijani Własowcy, [Tomek] ominął ich ostrożnie i zszedł do piwnicy. O przejściu przez bramę, nie było co marzyć. Żołnierze ułożyli tam sobie zdobyczne materace i kołdry i leżeli pokotem. W piwnicy Tomek odkrył zbiorowy grób - częściowo spalone zwłoki ludzi, leżących w przejściu. Korytarz piwniczny był jednym grobem. [...] w tym domu, w tych piwnicach, zginął Ryszard Jahołkowski, mój brat stryjeczny i mój ojciec chrzestny. To była makabryczna egzekucja, kazali ludziom stawać na schodach do piwnicy i strzelali w tył głowy. I tak rozstrzelali wszystkich mieszkańców ${ }^{90}$.

Po wojnie Nadzieja Drucka pozostała w Polsce, od 1947 do 1949 r. pracowała w warszawskim Biurze Odbudowy Stolicy, a następnie zajęła się działalnością

87 N. Drucka, Trzy czwarte..., s. 151.

88 Archiwum Muzeum Powstania Warszawskiego (dalej: AMPW), V/73, Relacja Irena Semadeni-Konopacka, Rozstrzelania ludności cywilnej i żołnierzy AK na terenie Warszawy, tj. na Powiślu, b.d., k. 11, 12.

89 B. Urbanek, Pielegniarki i sanitariuszki w Powstaniu Warszawskim w 1944 r., Warszawa 1988, s. 252, 365, 369; http://www.1944.pl/historia/powstancze-biogramy/Nadzieja_OBrien_De_Lacy (dostęp: 17.01.2017); http://www.1944.pl/historia/powstancze-biogramy/Irena_OBrien_De_Lacy (dostęp: 17.01.2017).

90 AMPW, P/5187, Relacja Margaret O’Brien - Ochota, b.d., k. 3. 
literacką. Była odznaczona Krzyżem Kawalerskim Orderu Odrodzenia Polski (Polonia Restituta). Mieszkała w Warszawie aż do swej śmierci 29 sierpnia 1986 r. Księżna została pochowana na cmentarzu prawosławnym w Warszawie ${ }^{91}$.

\section{Rosjanie z Nowogródczyzny i Wileńszczyzny}

Z Kresów Wschodnich, stanowiących istną mozaikę narodowościową, pochodziło kilku obywateli RP, wywodzących się z rodzin porewolucyjnej emigracji rosyjskiej. Kilkoro $\mathrm{z}$ nich okazało się polskimi patriotami, ujawniając głębokie zaangażowanie żołnierskie. Zapisali się złotymi zgłoskami w historii Armii Krajowej, walczącej na Nowogródczyźnie i Wileńszczyźnie.

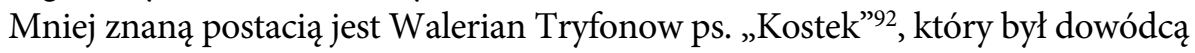
placówki AK Horodyszcze w Nowogródzkim Okręgu AK. Walczył on z okupantem niemieckim i partyzantką sowiecką. Słabość polskich sił ujawniła się z chwilą wybuchu konfliktu $\mathrm{z}$ „ludowymi mścicielami”. Walki z „sojusznikami naszych sojuszników" zainicjowało spacyfikowanie 8 maja 1943 r. miasteczka Naliboki, a dodatkowo wymordowanie 29 stycznia 1944 r. mieszkańców „reakcyjnej” wsi Koniuchy. Wrogim działaniem było - w oparciu o rozkaz Pantielejmona Ponomarianki 14 listopada 1943 r. - rozbrojenie Polskiego Oddziału Partyzanckiego (POP). To zainicjowało walki sowiecko-polskie i przyczyniło się do polsko-niemieckiego „zawieszenia broni”. Przeciwko temu porozumieniu wystąpiła zresztą KG AK w Warszawie, opierając się na zasadzie „sojuszników naszych sojuszników”, która z perspektywy lokalnej była odbierana z niezrozumieniem. W sytuacji narastającego konfliktu z partyzantami sowieckimi sierżant Tryfonow podjął pertraktacje z Niemcami, aby poprzez zawieszenie broni z nimi wzmocnić siły polskiej partyzantki oraz móc uwolnić aresztowanych konspiratorów AK i ich rodziny, osadzonych w obozie koncentracyjnym w Kołdyczewie (pow. baranowicki) ${ }^{93}$.

Negocjacje z Niemcami zakończyły się tragicznie, na co mogły wpłynąć negatywne polskie oceny wcześniejszych pertraktacji rotmistrza Józefa Świdy ps. „Lecha” oraz dowództwa Zgrupowania Nadniemeńskiego AK z lokalnymi władzami niemieckimi. Ponadto Niemcy mogli się zorientować, że Tryfonow zdezerterował w maju 1943 r. z Białoruskiej Obrony Krajowej (Беларуская Краёвая Абарона

91 Wspótcześni polscy pisarze i badacze literatury. Słownik bibliograficzny, t. 2, red. J. Czachowska, A. Szałagan, Warszawa 1994, s. 209-211.

92 Bardzo skąpe informacje na jego temat sygnalizują jego wcześniejszą służbę w WP jako plutonowego rezerwy w 16. pułku piechoty im. Ziemi Tarnowskiej.

93 B. Chiari, Kriegslist oder Bündnis mit dem Feind? Deutsch-polnische Kontakte 1943/44, w: Die polnische Heimatarmee. Geschichte und Mythos der Armia Krajowa seit dem Zweiten Weltkrieg, red. B. Chiari, J. Kochanowski, München 2003, s. 497; K. Krajewski, Na straconych posterunkach. Armia Krajowa na Kresach Wschodnich II Rzeczypospolitej 1939-1945, Kraków 2015, s. 205; idem, Der Bezirk Nowogródek der Heimatarmee. Nationalitätenkonflikte und politische Verhältnisse 1939 bis 1945, w: Die polnische Heimatarmee..., s. 580-582. 
- БKA-BKA). „Kostkowi” nie udało się doprowadzić do zwolnienia Polaków z KL Koldyczew (Kołdyczew), a także Baranowicz. Tymczasem niemiecka policja, wspierana przez batalion BKA, przeprowadziła operację w ramach Bandenbekämpfung, rozbijając 22 maja 1944 r. 40-osobowy, słabo uzbrojony „zawiązek oddziału partyzanckiego ośrodka Baranowicze" we wsi Przewłuka (Przewłoka) w okolicy Horodyszcza. W walce poległo 16-20 żołnierzy AK, a niemieccy i białoruscy policjanci spalili też wspomnianą wieś, mordując jej stu mieszkańców. Pozostali przy życiu konspiratorzy wycofali się do Puszczy Nalibockiej. Tam Tryfonow z 20 żołnierzami skontaktował się 20 maja z sowieckim oddziałem im. Budionnego Brygady Partyzanckiej im. 25 lat BSSR. Kilka dni sierż. „Kostek” pozostawał dowódcą, będąc kontrolowanym przez zastępcę ds. politycznych Makowskiego. Sowieccy partyzanci nie ufali przybyszom z AK - a po kilku dniach Tryfonow z zastępcą Stanisławem Rowińskim i szefem sztabu Kazimierzem Olifierką „zostali zastrzeleni za szpiegostwo", zaś jego podwładni walczyli w partyzantce sowieckiej do czasu wcielenia do Armii Czerwonej ${ }^{94}$.

Równie nieznani pozostają żołnierze III batalionu 77. pułku piechoty AK Uderzeniowych Batalionów Kadrowych. Strzelec Karol Jakimow ps. „Lolek” służył w plutonie łączności, dowodzonym przez ppor. Stefana Teodorowicza ps. „Stefan”. „Lolek” uczestniczył w maju 1944 r. w akcji zdobycia samochodu ciężarowego Panhard w okolicach Lidy. Rosjanin zginął 7 lipca 1944 r. podczas akcji „Ostra Brama”, walcząc pod wsią Góry. Równie niewiele wiemy o Janie Ławrientiewie ps. „Felek”. W tym samym pododdziale służyła sanitariuszka Zofia Ławrientew ps. „Zoja”. Wcześniej, pracując jako sekretarka w komendanturze Organizacji Todt (Organisation Todt - OT), rozpoznawała ona zachowania Niemców i pomogła 7 kwietnia 1944 r. patrolowi UBK dowodzonemu przez pchor. Mieczysława Lipko ps. „Satyr” w rozbrojeniu magazynu OT w Lidzie. Później Rosjanka zatrudniła się jako pomoc kuchenna w Stützpunkcie w majątku Dworzyszcze, a jej zadaniem było rozpoznanie w budynku. Grupa szturmowa wyłoniona z żołnierzy III/77. pp AK zdobyła punkt umocniony, zdobywając duże ilości broni strzeleckiej oraz dwa samochody ${ }^{95}$.

Dwaj bracia Kuroczkinowie dali przykład wzorcowego patriotyzmu polskiego. Ale stwierdzenie, że byli emigrantami, nie jest do końca precyzyjne. Mikołaj urodził się 3 kwietnia 1914 r. jako syn Aleksego i Stanisławy z d. Wyrzykowskiej, będąc jeszcze poddanym cesarza Mikołaja II. Jednak w wyniku I wojny światowej,

${ }^{94}$ Armia Krajowa $w$ dokumentach 1939-1945, t. 3: Kwiecień 1943 - Lipiec 1944, Londyn 1976, s. 473-474 oraz Nowogródzki Okręg AK w dokumentach, oprac. K. Krajewski, Warszawa 2009, s. 50; K. Krajewski, Na straconych posterunkach..., s. 224; Z. Boradyn, Niemen rzeka niezgody. Polsko-sowiecka wojna partyzancka na Nowogródczyźnie 1943-1944, Warszawa 2013, s. 188-189.

95 K. Krajewski, Uderzeniowe Bataliony Kadrowe 1942-1944, Warszawa 1993, s. 416, 421-422, 449-452, 466, 485. Dodatkowe ustne wiadomości uzyskane od autora monografii wskazały, że Zofia Ławrientew została wcielona do „ludowego” Wojska Polskiego, w którym popełniła samobójstwo w 1945 r. [Za informację dziękuję dr. Kazimierzowi Krajewskiemu]. 
przedłużonej w Europie Wschodniej do 1921 r., Kuroczkin jako rodowity Wilnianin stał się obywatelem Polski i członkiem sporej rosyjskiej diaspory miasta nad Wilią. Jako 21-latek rozpoczął jednoroczne przeszkolenie wojskowe w elitarnym 1. pułku piechoty Legionów. Następnie podjął studia na wileńskim Uniwersytecie Stefana Batorego (USB), zapewne spotykając tam studentkę Lidię Lwow, o której niżej. Kuroczkin należał do Akademickiego Konwentu „Ruthenia Vilnensis”, a prawdopodobnie też do Związku Rosyjskich Studentów Uniwersytetu Stefana Batorego (Союз русских студентов УСБ) ${ }^{96}$.

Wybuch oraz przebieg wojny prowadzonej przez Niemcy i Związek Sowiecki z Polską doprowadził do czasowego znalezienia się Wilna w granicach Litwy. Młody Rosjanin mógł konspirować w Samodzielnym Okręgu ZWZ Wilno, czyli występować już wówczas przeciw Litwinom. Ważne dla niego było zachowanie odpowiedniej kondycji fizycznej. Kuroczkin był zapalonym sportowcem i entuzjastą lotów na lotni. Dziesięcioletnie uprawianie lotniarstwa pozwoliło mu prawdopodobnie na przeprowadzenie 12 maja $1942 \mathrm{r}$. lotu na mięśniolocie, dzięki czemu miał być pierwszym zawodnikiem na ziemiach polskich, mającym na koncie tego rodzaju wyczyn ${ }^{97}$.

Kuroczkin trafił 13 września 1943 r. do Oddziału Lotnego im. Króla Bolesława Chrobrego i został zaprzysiężony jako żołnierz AK. „Osobiście znałem jedynie «Leszczynę", i braci Kuroczkinów to jest «Wiąza» i "Leśnego». Uzbrojenie, jak już wspomniałem, było marne. Ubrani byliśmy w różne cywilne ciuchy. Jedynie «Leśny» miał na sobie polski mundur wojskowy" - wspominał Marian Korejwo ps. „Milimiter”. W listopadzie „Wiąz”, „Leśny” z jeszcze jednym partyzantem "pojechali z jakimś zadaniem zleconym przez Komendanta do Oszmiany. Po drodze trafili na oddział partyzantki sowieckiej. Zostali okrążeni i rozbrojeni. Był to ten sam oddział, z którym niedawno mieliśmy dagawory. Szczęśliwie wypuszczono ich wolno, lecz broni nie zwrócono” - zapamiętał „Milimiter”. Zaś kilka

${ }^{96}$ Ruthenia Vilnensis była korporacją rosyjskiej mniejszości narodowej. Kuratelę z ramienia uniwersyteckiego Senatu sprawował prof. Sergiusz Schilling-Siengalewicz, a siedziba mieściła się przy ul. Skopówka 5/4. Niekompletna imienna lista członków obejmuje poza Kuroczkinem dwa nazwiska: Dymitra Twierdochlebowa (studenta medycyny USB z Nowogródczyzny, który zginął tragicznie w ostatnim prawdopodobnie śmiertelnym pojedynku na ziemiach polskich) oraz Mariana Zdziechowskiego (30.04.1861 w Nowosiółkach - 5.10.1938 w Wilnie), krytyka, historyka literatury i kultury, filozofa, prof. UJ, dziekana, rektora USB, dr. hc Uniwersytetu w Tartu, członka PAU. Był on członkiem honorowym Korporacji Ruthenia Vilnensis. Członkowie rosyjskiej korporacji nosili ciemnogranatowe dekle, zob.: AIPN GK, 919/2656, Ankieta personalna Mikołaja Kuroczkina, k. 1; P. Tomaszewski, Polskie korporacje akademickie w latach 1918-1939. Struktury, myśl polityczna, działalność, Toruń 2011, s. 459-460; Archiwum Korporacyjne. Archiwum i Muzeum Polskich Korporacji Akademickich [zob.: VIII. Akademicki Konwent „Ruthenia Vilnensis"] na: http://www.archiwumkorporacyjne.pl/index.php/muzeum-korporacyjne/wilno/ pozostale/ (dostęp: 17.01.2017).

97 Konspiracja i opór społeczny w Polsce 1944-1956. Słownik biograficzny, t. 2, red. T. Balbus [et al.], Kraków-Warszawa-Wrocław 2004, s. 186-187 (biogram Mikołaja Kuroczkina autorstwa J. Kułaka). 
dni przed Bożym Narodzeniem „Wiąz” i „Leśny” poparli „Szczerbca” przy próbie zdjęcia go ze stanowiska dowódcy 3. Brygady AK. Od stycznia do czerwca $1944 \mathrm{r}$. Mikołaj Kuroczkin pozostawał żołnierzem dyspozycyjnym i łącznikiem 3. Brygady Partyzanckiej AK na terenie Wilna, mieszkając przy ul. Krzywe Koło, obok domu, który zajmowała żona „Szczerbca”, która była jednocześnie jego krewną ${ }^{98}$.

W lipcu 1944 wziął udział w operacji „Ostra Brama”. Po zdobyciu Wilna przez Sowietów niezdekonspirowanemu Kuroczkinowi udało się zdobyć posadę zawiadowcy na stacji kolejowej Dworzec Wilno (Станция Вильнюсский вокзал), gdzie był zatrudniony od lipca do grudnia 1944 r. W ten sposób uchylił się od rejestracji i służby wojskowej w 1 . Armii Polskiej gen. Berlinga ${ }^{99}$.

Następnie Kuroczkin został repatriowany w grudniu 1944 r. w ramach działań delegacji Polskiego Komitetu Wyzwolenia Narodowego (PKWN) do Białegostoku. Tu udało mu się zmylić funkcjonariuszy filtracyjnych UB i wyjechał do pobliskiej Hajnówki, gdzie zatrudnił się w Okręgowej Dyrekcji Lasów Państwowych. Wkrótce w lutym 1945 r. został przeniesiony do 2. plutonu 4. kompanii samodzielnego batalionu ochrony lasów państwowych, podporządkowanego Naczelnej Dyrekcji Lasów Państwowych. Tam objął stanowisko zastępcy dowódcy tego pododdziału (jego zwierzchnikiem był „Bury”, występujący jako ppor. Jerzy Góral ${ }^{100}$ ). Puszcza Białowieska stała się miejscem spotkania „Leśnego” z „łupaszkowcami”, gdy podchorąży Kuroczkin patrolował las z podkomendnymi. Po pertraktacjach partyzanci wypuścili ich i oddali im broń. Kuroczkin otrzymał kontakty na komendanta rejonu Armii Krajowej/Armii Krajowej Obywatelskiej Hajnówka Tadeusza Siedleckiego ps. „Tadeusz” i Jadwigę Laskowską ${ }^{101}$. „Pamiętam, że do pierwszego spotkania doszło właśnie w holu dyrekcji tartaku [w Hajnówce]. Ludzi na korytarzu kupa i wśród nich «Bury» i «Kolka» [Mikołaj Kuroczkin]. [...] Rozmawiał z nimi «Słoń». Sprawiali wrażenie, jakby się już znali” wspominał świadek spotkania, łącznik st. Ułan Rajmund Drozd ps. „Mikrus”102.

To wówczas „interesanci” ustalili szczegóły wizyty „Burego” u „Łupaszki”, do której doszło przed 5 kwietnia, gdy wypadały Święta Wielkanocne. Wkrótce Kuroczkin został oddelegowany do Liten (Lilen?) ${ }^{103}$, gdzie otrzymał dowództwo nad plutonem ochrony lasów państwowych - ale nie jest to do końca potwierdzone. Po trzech miesiącach Rosjanin zdezerterował z całym plutonem, podporządkowując

98 M. Korejwo, Moje ścieżki partyzanckie. W 3. Wileńskiej Brygadzie Armii Krajowej „Szczerbca”, Warszawa-Kraków 2014, s. 22, 62, 159.

99 O. Christa, $U$ „Szczerbca” i „, uupaszki”, Warszawa 2000, s. 141; J. Kułak, Rozstrzelany oddział. Monografia 3 Wileńskiej Brygady NZW Białostocczyzna 1945-1946, Białystok 2007, s. 58-59; P. Niwiński, Okręg Wileński AK w latach 1944-1948, Warszawa-Kraków 2014, s. 92-95 oraz

L. Tomaszewski, Wileńszczyzna lat wojny i okupacji 1939-1945, Warszawa 2010, s. 524-534.

100 Nieznana jest przyczyna obniżenia o jeden stopień oficerski „Burego” - można przypuszczać, że Rajs przekazał władzom komunistycznym fałszywe informacje.

101 O. Christa, op. cit., s. 132; J. Kułak, Rozstrzelany oddział..., s. 91-92.

102 J. Kułak, Rozstrzelany oddział..., s. 98-99 (fragment relacji Rajmunda Drozda ps. „Mikrus”).

${ }_{103}$ Najprawdopodobniej chodziło o Lilienfeld czyli Lelice. 
się 10 maja 1945 r. dowództwu 5. Brygady Wileńskiej AK majora Zygmunta Szendzielarza ps. „Łupaszko”. Całą akcją przejścia swego byłego podwładnego do podziemia pokierował „Bury”, a przy okazji „Leśny” powiadomił o celach wyjazdu trzydziestoosobowego 2. plutonu $\mathrm{w}$ innym kierunku - w okolice nadleśnictw Brańsk, Rudka i Pietrowo ${ }^{104}$.

Po zakończeniu II wojny światowej 31-latek nie zdecydował na ujawnienie ani zalegalizowanie się w Polsce rządzonej przez PKWN (a wkrótce przez Tymczasowy Rząd Jedności Narodowej - TRJN) na fałszywych papierach. Brygada, a wraz z nim II szwadron szybko powiększały swój stan osobowy, osiągając liczbę 300 żołnierzy - ich zadaniami było głównie eliminowanie aktywnych komunistów z PPR, funkcjonariuszy UB i MO oraz podejrzanych o współpracę z NKWD i UB. Już dwa dni po dołączeniu pododdziału „Burego" i „Leśnego” do 5. Brygady doszło 12 maja do ich pierwszej akcji: „nowo przybyłych żołnierzy z Ochrony Leśnej wysłałem ich na zasadzkę na szosę płd. od m. Dziatkowice. Stoczyli oni walkę $\mathrm{z}$ autem sow. [ieckim], zabijając trzech żołnierzy (czwarty zmarł $\mathrm{z}$ ran w lesie) i zdobyli sprzęt radiowy nad.[awczo]-odbiorczy, który przekazałem ob. «Koryckiemu» [kpt. Jan Trusiak - komendant Obwodu Bielsk Podlaski - H.K.]". Szwadron prowadził też szkolenia, przeprowadził rajd z całą brygadą na południowy brzeg Bugu, rozbrajał, ale i rozstrzeliwał milicjantów, np. w Hołowczycach, konfiskował towary i pieniądze w magazynach i urzędach, część zawsze rozdając ludności miejscowej. Ponadto Kuroczkin (jak i Jurasow) brali udział w ataku na kolumnę samochodową prokuratury sowieckiej 5. Armii Pancernej - jej oficerowie i żołnierze zostali zatrzymani i rozstrzelani 7 lipca $1945 \mathrm{w}$ podlaskiej wsi Brzeziny przez 1. i 2. szwadron 5. Brygady. Następnie Rosjanin został wyznaczony 16 września 1945 r. na zastępcę dowódcy nowo utworzonej 3. Wileńskiej Brygady NZW, której dowódcą pozostał ppor. „Bury”. Już 30 września 1945 r. „Leśny” został przeniesiony na stanowisko komendanta Powiatu NZW Łomża („Łaba”) - walczył od września do grudnia 1945 r. w Narodowym Zjednoczeniu Wojskowym (NZW) ${ }^{105}$.

104 Podczas ostatniego przejazdu służbowego z Hajnówki do Białegostoku „Bury” z „Leśnym” spotkali przypadkowo plut. Kazimierza Chmielowskiego ps. „Rekin”, który dwa dni wcześniej powrócił do stolicy Podlasia po brawurowej ucieczce z obozu w Kałudze. Idąc ulicą z Aleksandrem Domalewskim ps. „Ryży” został „Rekin” wciągnięty przez „Leśnego” do ciężarówki ku konsternacji zdumionego kolegi. Natomiast dwaj specjaliści od partyzantki niepodległościowej sugerowali błędnie o podporządkowaniu się ppor. „Burego” mjr „Łupaszce” już podczas jego koncentracji 5.04.1945, zob.: K. Krajewski, T. Łabuszewski, Białostocki Okręg AK-AKO. VII 1944 - VIII 1945, Warszawa 1997, s. 256; J. Kułak, Rozstrzelany oddział..., s. 102-103.

105 AIPN BU, 1820/2, Ministerstwo Sprawiedliwości, Centralny Zarząd Zakładów Karnych, Lista osób zmarłych w więzieniach polskich w latach 1944-1956, cz. 1, t. 2, Więzienia karno-śledcze, Warszawa, III 1993, k. 134 (Mikołaj Kuroczkin, s. Aleksego); AIPN GK, 919/2656, Wyrok w imieniu Rzeczpospolitej Polskiej dnia 1 grudnia 1946 [rozpoznawszy sprawę Mikołaja Kuroczkina]), k. 20-21, 26; M. Bechta, W.J. Muszyński, Przeciwko Pax Sovietica. Narodowe Zjednoczenie Wojskowe i struktury polityczne ruchu narodowego wobec reżimu komunistycznego 1944-1956, Warszawa 2017, s. 260-261 oraz K. Krajewski, T. Łabuszewski, Białostocki Okręg AK-AKO..., s. 270-271. 
Wkrótce, bo w końcu 1945 r. Kuroczkin otrzymał zgodę na zalegalizowanie pobytu poza macierzystym Białostockim Okręgiem NZW - prośbę motywował chęcią podjęcia studiów. Rosjanin przyjechał na początku października $1945 \mathrm{r}$. do Warszawy, gdzie nawiązał łączność z mjr. Marianem Kamińskim „Rawiczem” (komenda I Obszaru NZW - Warszawa). Po niecałym miesiącu „Leśny” został aresztowany ze swoim dowódcą Romualdem Rajsem „Burym” w warszawskim lokalu konspiracyjnym NZW przy ul. Środkowej. Jednak nierozpoznani przez UB konspiratorzy zostali zwolnieni. Wówczas Kuroczkin podjął nieskuteczną próbę dostania się na Politechnikę Krakowską, po czym w połowie listopada powrócił do Warszawy. Komenda I Obszaru NZW skontaktowała go z szefem PAS KG NZW kpt. Janem Morawcem ps. „Henryk”, „Remisz”. Ten skierował „Leśnego” w połowie grudnia do Katowic, aby objął elitarny pion PAS, mający być podstawą odtwarzanego Okręgu VIII NZW Górny Śląsk-Zagłębie (krypt. „Traugutt”). Zadanie zaczął realizować od połowy grudnia 1945 r. „Leśny” (a po zmianie pseudonimu „Polus”), mając ustalony punkt kontaktowy w Warszawie w mieszkaniu przy ul. Wołoskiej $74 \mathrm{~m}$. 10. Kuroczkin otrzymał niewielkie wsparcie finansowe, odebrał pisemne instrukcje ze schematem organizacyjnym PAS, wnioskami awansowymi etc. Nawiązawszy pierwsze kontakty w terenie, ale nie doczekawszy się przyjazdu kpt. „Remisza” w katowickim lokalu konspiracyjnym, nie próbował już dalej działać (przy czym szef PAS nie mówił nic o odwołaniu Kuroczkina z funkcji komendanta PAS Okręgu Śląskiego, utrzymując z nim kontakt do marca 1946 r.).

Z końcem roku wyjechał do Wrocławia, pragnąc rozpocząć nowe życie czego symbolem było rozpoczęcie studiów na Wydziale Chemii Politechniki Wrocławskiej. Na Dolnym Śląsku Kuroczkin zwerbował do NZW i mianował nieformalnym zastępcą poznanego w Warszawie por. Stefana Jabłońskiego „Vis”. Początek stycznia 1946 r. to seria przejazdów obu żołnierzy NZW w poszukiwaniu „Remisza”. Najpierw szukali go w Warszawie, potem w Łodzi, następnie z powrotem w stolicy. Ostatecznie Kuroczkin zarekomendował szefowi PAS por. Jabłońskiego jako swego następcę, co motywował chęcią studiowania. „Polus” z „Visem” pojechali pod koniec stycznia lub na początku lutego $1946 \mathrm{r}$. na odprawę organizacyjną oficerów PAS, która miała miejsce w Łodzi przy ul. Głównej. Mimo początkowego braku zgody doszło do zmiany na stanowisku szefa śląskiego PAS. Ostatecznie „Remisz” zgodził na rezygnację Kuroczkina z pełnionej funkcji, ale „Polus” miał pozostawać w dyspozycji NZW.

UB aresztował Kuroczkina już w marcu 1946 r., gdy został zidentyfikowany jako jeden $\mathrm{z}$ liderów studenckich protestów w akademiku. Niezadowolenie wyrażane po niezapowiadanym wyłączaniu światła, uniemożliwiającym studentom naukę w czasie sesji egzaminacyjnej, przyczyniło się do jego zatrzymania i przesłuchiwania. Po wyrażeniu zgody na współpracę z wrocławskim WUBP Kuroczkin wyszedł na wolność, ale wówczas zdecydował się na ucieczkę za granicę. Porucznik Lechosław Roszkowski „Tomasz” skierował „Polusa” na punkt kontaktowy komendy Morskiego Okręgu NZW w Gdyni. Kuroczkin dotarł pod 
koniec marca na Wybrzeże. Dwa miesiące bezskutecznie oczekiwał na przerzut, do którego ostatecznie nie doszło. Rosyjski „żołnierz niezłomny” został aresztowany 11 maja 1946 r. w Gdańsku. Stracono go 19 lutego 1947 r. (druga wersja wspominała o 18 lutego 1947 r.) w więzieniu przy ul. Rakowieckiej w Warszawie. Miejsce jego pochówku jest nadal nieznane ${ }^{106}$.

O drugim z braci Kuroczkinów, Anatolu, wiemy o wiele mniej. Przed wojną trenował w Wileńskim Towarzystwie Wioślarskim. Stąd była prosta droga do konspiracji - Anatol Kuroczkin tworzył konspiracyjną piątkę z Witoldem Mikuliczem-Radeckim ps. „Swing”, Wiktorem Romanowskim ps. „Mister”, Marianem Korejwo ps. (ówczesny) „Jawor” oraz sternikiem Henrykiem Rochlickim ps. „Leszczyna”. Następnie we wrześniu 1943 r. trafił wraz z bratem do Oddziału Lotnego im. Króla Bolesława Chrobrego. Jego pseudonim brzmiał „Wiąz”. Starszy z braci używał rewolweru 7,62 mm wz. 95 „Nagant”107.

Anatol $\mathrm{z}$ bratem Mikołajem oraz innymi partyzantami polskimi wzięli udział w puczu, stając po stronie swego dowódcy kpt. Gracjana Froga ps. „Szczerbiec”. Od stycznia 1944 r. Anatol i Mikołaj Kuroczkinowie pozostawali żołnierzami dyspozycyjnym 3. Brygady AK na terenie Wilna ${ }^{108}$.

Ze wspomnień Olgierda Christy możemy wysnuć przypuszczenie na temat aktywności Mikołaja na podstawie opisu aktywności jego brata, Anatola:

W Wilnie rezydowała ekspozytura brygady pod kierunkiem Wiktora Romanowskiego ps. Mister z zastępcą Anatolem Kuroczkinem „Wiązem”, wspierająca brygadę przede wszystkim w łączności z Komendą Okręgu. Zobowiązana była do działań na rzecz oddziału, określanych dzisiaj jako logistyczne. Formowała i wysyłała grupy wolontariuszy, organizowała transport zaopatrzenia medycznego, butelek zapalających [...]. Agentura, jak ją niekiedy zwano, umieszczała rannych w szpitalach lub w konspiracyjnych mieszkaniach, współdziałała z delegowanymi do miasta patrolami wykonującymi określone zadania [...]. Improwizowaną pomyślnie zakończoną akcją dowodził „Mister” na czele grupy w składzie: Anatol Kuroczkin „Wiąz”, Władysław Baniuk „Turmont”, Zdzisław Christa „Mamut” oraz Ryszard Poszytek „Bałtyk”109.

Kolejnym obywatelem II RP pochodzenia rosyjskiego (i wyznania prawosławnego) był Włodzimierz Jurasow ps. „Wiarus”, pochodzący z Wileńszczyzny. Urodził się 26 sierpnia 1923 r. w Wilnie, był synem Jerzego i Marii, Rosjan należących do kościoła prawosławnego. Włodzimierz pobierał nauki w wileńskim Gimnazjum

106 AIPN BU, 944/109, Akta sprawy przeciwko Michałowi Galejowi i in., Protokół przesłuchania podejrzanego Mikołaja Kuroczkina, 14.08 .1946 r., k. 170-174; Protokół przesłuchania podejrzanego Mikołaja Kuroczkina; 21.08. 1946 r., k. 186-189v; AIPN BU, 944/110, Akta sprawy przeciwko Michałowi Galejowi i in. Protokół przesłuchania świadka Jana Morawca, 14.08.1946 r., k. $154-156$.

107 M. Korejwo, op. cit., s. 19-20.

108 O. Christa, op. cit., s. 52-53.

109 M. Korejwo, op. cit., s. 64-65. 
i Liceum im. Króla Zygmunta Augusta. Ze środowiska szkolnego wywodziło się wielu przyjaciół Jurasowa, którzy wkrótce staną się partyzanckimi legendami. Pozaszkolne zajęcia Włodzimierza zdominowało żeglarstwo, gdy dostał się do 1. Wileńskiej Drużyny Harcerzy im. Romualda Traugutta tzw. Błękitnej Jedynki Żeglarskiej.

Po wybuchu II wojny światowej, choć raczej dopiero po czerwcu 1941 r., a „najpewniej w końcu 1942 r.”, zaczął konspirować w Samodzielnym Okręgu ZWZ Wilno. Przystań Błękitnej Jedynki Żeglarskiej u zbiegu Wilii i Wilenki (Wilejki) była miejscem spotkań konspiracyjnych wileńskiej AK. Po półtora roku, 22 października 1943 r. doszło do przerzutu samochodem ciężarowym dziesięciu konspiratorów, pod wodzą Mariana Korejwy ps. „Milimetr”. Ochotnicy-wilniacy trafili do oddziału por. Gracjana Froga ps. „Góral” (od listopada 1943 r. ps. „Szczerbiec”). Tak to zapamiętał Józef Bandzo ps. „Jastrząb”, który dwa tygodnie wcześniej przed Jurasowem trafił do oddziału: „Było nas dwudziestu czterech. Jak oni dołączyli [wspomniana dziesiątka „Milimetra”] było nas trzydziestu czterech. Poznałem Jurasowa w październiku 1943. Koledzy mówili, że Jurasow to Rosjanin, choć nikt nikogo nie wypytywał, kto kim jest. Jeden do drugiego coś tam powiedział, ale znaliśmy się pod swoimi pseudonimami. Później się blisko przyjaźniłem z Jurasowem, ale na terenach za linią Curzona”. Tak powstawał trzon 3. Brygady Wileńskiej AK ${ }^{110}$.

Dowódca przydzielił Jurasowa, nadając mu ps. „Wiarus”, do sekcji „Milimetra” drużyny Władysława Markowskiego ps. „Dżumba”. Rosjanin złożył przysięgę 11 listopada 1943 r., rozpoczynając życie partyzanta AK, lecz nie posiadając żadnych umiejętności żołnierskich. „Wiarus” pod ostrym drylem Romualda Rajsa ps. „Bury” przeszedł intensywne szkolenie, uzyskując wysoką sprawność bojową. Marian Korejwo zapamiętał, kto objął szefostwo wyszkolenia:

kpr. zawodowy „Bury” (ćwiczenia), który w Brygadzie awansował do stopnia podporucznika. [...] Przed wojną pełnił służbę w 85. pułku piechoty w Nowej Wilejce. Był to doskonały szkoleniowiec, bezlitosny w osiąganiu podstawowych celów. Wypruwał z nas ostatnie poty i siły. [...] zamiast odpoczynku lub wolnego czasu mieliśmy naukę o broni, topografię, czyszczenie broni itp. Poznawanie broni, którą posiadaliśmy, było dokładne i dogłębne ${ }^{111}$.

Włodzimierz charakteryzował się dużą tężyzną fizyczną, co udowodnił na początku listopada 1943 r., umożliwiając 38-osobowemu oddziałowi przeprawienie się przez rzekę: „Wtedy dwóch naszych chłopaków - jeden z nich «Wiarus» był pływakiem - pomimo lodowatej wody, gdyż był to początek listopada, przepłynęli wpław dość szeroką w tym miejscu rzekę [Wilia] i przeciągnęli prom na naszą stronę"112.

Jednym z pierwszych zadań bojowych „Wiarusa” był udział $\mathrm{w}$ ataku na miasteczko Worniany, gdzie został rozbity posterunek obsadzony przez pluton Litauische Polizei Bataillon F/256. Po wypożyczeniu młotów kowalskich oddział

110 Relacja Józefa Bandzo, VI 2015, zbiory własne.

111 M. Korejwo, op. cit., s. 45

112 Ibidem, s. 44. 
AK uwolnił z miejscowego aresztu 70 osób (w tym grupy Żydów), rozbijając więzienną bramę. Jesień 1943 r. to już czas (po Nalibokach) otwarcie wrogich relacji z sowiecką partyzancką, działającą na Kresach Wschodnich (Zachodnia Białoruś i Białostocczyzna). Oddziały walczące z „biało-Polakami” z AK podlegały Białoruskiemu Sztabowi Ruchu Partyzanckiego (Белорусский штаб партизанского движения). Przykładowo: „[w] połowie listopada 1943 r. w pobliżu Mikuliszek grupa sowiecka została ostrzelana przez stojącego na warcie "Wiarusa»"113.

Już po tym incydencie Jurasow w grudniu 1943 r. dołączył do 3. Brygady AK. Olgierd Christa tak zapamiętał pierwsze partyzanckie spotkanie "gimnazjalnego i trzeciobrygadowego kolegi [jak go określił] z pochodzenia Rosjanina”: „W grupie spotkałem kolegów gimnazjalnych Włodzimierza Jurasowa «Wiarusa» i Henryka Siemaszkę «Dłuższego». Zaimponowali nam uzbrojeniem, lornetkami, skrzyżowanymi na piersiach paskami [koalicyjkami, będącymi oporządzeniem wojskowym]. Był okres wczesnozimowy, $\mathrm{z}$ braku płaszczy wojskowych nosili półkożuszki wygodne w czasie marszu. Włodzimierz uczestniczył w kolejnych walkach oddziału"114.

Początek roku rozpoczął się od odparcia ataku plutonów policji pomocniczej litewskiej oraz żandarmerii niemieckiej pod dowództwem Leutnanta Schnabela przez partyzantów AK. Polacy kwaterowali 8 stycznia 1944 r. w Mikuliszkach. "Wiarus”, znakomicie wyszkolony w obsłudze swojego 7,62 mm ręcznego karabinu maszynowego Diegtiariow DP wz. 1927 (DP-27): „Demonstrował sposób rozbierania i składania erkaemu «Wiarus». Był on pierwszym sekcyjnym i do tego celowniczym omawianego erkaemu. [...] Zaraz za mną przypełzł «Wiarus» ze swoim amunicyjnym «Szwagrem». «Wiarus» ustawił pomiędzy domem, a sągiem drzewa swojego diegtara [rkm DP-27] i zaczął kosić po tyralierze wroga. Ta zaś zaraz w tym miejscu pękła i ci, co pozostali przy życiu zaczęli uciekać, by schować się za krzaki na bagnach” - wspominał „Milimiter”115.

Polaków wsparł oddział rozpoznania konnego. Kawalerzyści uderzyli we flankę tyraliery, zmuszając Litwinów do odwrotu, którzy stracili do 33 zabitych, w tym ppor. Schnabela. Poległo pięciu partyzantów AK, m.in. por. Piotr Motylewicz ps. "Szczepcio" - wszyscy zostali pochowani w Mikuliszkach, gdzie na miejscowym cmentarzu zaczęto składać poległych żołnierzy „Szczerbca”. Od drugiej połowy grudnia 1943 r. do końca lutego 1944 r. 3. Brygada AK współpracowała z 6. Brygadą AK dowodzoną przez por. CC Adama Boryczkę ps. „Tońko”116.

Następnie Brygada „Szczerbca” przy współudziale 8. Brygady AK por. Witolda Turonka ps. „Tur”, 9. Brygady AK chor. Jana Kolendy ps. „Mały”, 12. Brygady AK

113 O. Christa, op. cit., s. 72; M. Korejwo, op. cit., s. 36 i 39-41; J. Bohdanowicz, 3. Brygada Szczerbca Armia Krajowa Okręg Wileński, Warszawa 2008, s. 4, http://www.muzeum-ak.pl/slownik/UserFiles/File/wilno-brygada-szczerbca.pdf (dostęp: 7.05.2017).

114 O. Christa, op. cit., s. 36-37.

115 M. Korejwo, op. cit., s. 80 i 83

116 E. Banasikowski, Na zew Ziemi Wileńskiej, Warszawa-Paryż 1990, s. 115-118; O. Christa, op. cit., s. 44-48 oraz M. Korejwo, op. cit., s. 65, 67-68. 
por./kpt. Hieronima Romanowskiego ps. „Cerber” i 13. Brygady AK por. Adama Walczaka ps. „Nietoperz” zdobyła w nocy z 13 na 14 maja 1944 r. miasteczko Murowana Oszmianka. W walce pokonały 1. kompanię 310. batalionu Litewskich Oddziałów Miejscowych/Litewskich Oddziałów Specjalnych (Lietuvos Vientiné Rinktine - LVR/Litauische Sonderverbände) por. Povilasa Grigaliunasa. W boju o Murowaną Oszmiankę 8. pluton (2. drużyna 1. pluton szturmowy) 3. Brygady AK był dowodzony przez Jurasowa. Ponadto została pokonana 2. kompania 310 . batalionu LVR kpt. Eduardasa Poczebutasa w Tołminowie. Litwini stracili 60 zabitych, ponadto 200 policjantów trafiło do niewoli - następnie zostali wypuszczeni w samej bieliźnie w kierunku Wilna, Jaszun i Oszmian. Zginęło 10-11 partyzantów AK oraz 20-25 zostało zranionych. „Wiarus” został awansowany na podporucznika czasu wojny. Innymi akcjami zbrojnymi 3 . Brygady AK były potyczki i dezorganizacja administracji niemieckiej w Adamkowszczyznie, Białej Wace, Czarnym Borze, Graużyszkach, Kieni, Mickunach, Pawłowie, Rudominie Sienkowszyznie, Szumsku czy Wojdatach. W lipcu 1944 r. Jurasow walczył o Wilno jako dowódca 1. plutonu w 4. kompanii w szeregach 3. Brygady Wileńskiej AK kpt. „Szczerbca”. Dalsze działania niepodległościowe Jurasowa na Wileńszczyźnie wiązały się z dramatem żołnierzy Wileńskiej AK, których dowódcy zostali aresztowani, a większość żołnierzy trafiła do obozu w Miednikach Królewskich ${ }^{117}$.

Po aresztowaniu „Szczerbca” pełniącemu obowiązki dowódcy 3. Brygady Wileńskiej AK ppor. Rajsowi udało się zdemobilizować większość podwładnych, a broń ukryć. Jednak 120-osobowa grupa partyzantów, wśród nich „Wiarus”, uzbrojona w stare belgijskie karabiny, zdecydowała się podążyć do Wilna, licząc na oficjalne rozbrojenie, co przeprowadziły oddziały Wojsk Wewnętrznych NKWD. Jak większość żołnierzy ppor. Jurasow został zesłany z kilkudziesięcioma żołnierzami 3. Brygady Wileńskiej AK, w sierpniu 1944 r. trafil do obozu filtracyjnego utworzonego w dawnych stajniach stadniny w Miednikach Królewskich, gdzie „było w obozie stłoczonych 7-8 tysięcy ludzi”. Stamtąd „Wiarus” uciekł z trzema kolegami, jak wspominał Marian Korejwo ps. „Milimetr”:

Porozumiałem się z „Wiarusem”, który był w 3. Brygadzie dowódcą plutonu w IV kompanii oraz z dwoma kolegami z VI Brygady „Konara”. Postanowiliśmy uciekać [...]. Idąc spokojnie minęliśmy jednego wartownika, a następnie drugiego. Będąc w połowie drogi między drugim, a trzecim wartownikiem, na dany sygnał, raptem wystartowaliśmy w lewo do krzaków. Ruszyliśmy sprintem, jakby to start do stumetrówki. [...] Po przebiegnięciu około $100 \mathrm{~m}$, skręciliśmy w kierunku północno-wschodnim na majątek [w pobliżu Miednik], gdzie miały na nas czekać ubrania i ewentualnie jakieś dokumenty.

117 AAN, T-311, rol. 213, kl. 000905-906, Bericht über Einsatz d. Litauische Polizei-Bataillonen in Raum Wehrmacht Befehlshaber Weissruthenien vom 19 Mai 1944; E. Banasikowski, op. cit., s. 128-135; O. Christa, op. cit., s. 81-82; M. Korejwo, op. cit., s. 77-79, 121-133, 142-143; N. Thomas, C. Caballero, Germany's Eastern Front Allies (2): Baltic Forces, Oxford 2012, s. 37-38. 
Dzięki otrzymanemu samogonowi mogli „za opłatę w płynnej walucie” przejechać się sowiecką ciężarówką, która dowiozła ich wsi Góry. Stąd pieszo przez Górną Kolonię Wileńską, ominęli patrole NKWD, docierając do rodzinnego miasta ${ }^{118}$.

Nic pewnego nie wiadomo na temat pobytu Jurasowa w Wilnie po ucieczce z obozu - zapewne, jak większość dotychczasowych konspiratorów, usiłował przeżyć, nawiązując pozrywane kontakty. Później, jak wielu jego kolegów poddał się repatriacji na tereny Polski za „linią Curzona”. Tuż po zakończeniu działań wojennych w maju 1945 r. Jurasowa spotkał w Krakowie dawny kolega z 3. Brygady Wileńskiej AK, Henryk Siemaszko ps. „Dłuższy”. Wówczas „Wiarus” oświadczył mu, że idzie walczyć o wolne wybory, na Białostocczyznę, do 5. Brygady mjr. Zygmunta Szendzielarza ps. „Łupaszka” ${ }^{119}$.

Do szeregów brygady dołączył ppor. Rajs „Bury”, dowodząc jej II szwadronem - wraz z nim służyli sierż. Kazimierz Chmielowski „Rekin”, sierż. pchor.l ppor. Mikołaj Kuroczkin „Leśny”, plut. Józef Bandzo „Jastrząb”, kpr. Tadeusz Urbanowicz „Moskito” oraz od lipca do września 1945 r. „Wiarus”. Demobilizacja 5. Brygady AK nie oznaczała zakończenia zmagań „Wiarusa”, który podporządkował się komendzie Okręgu Białystok NZW ze swym przełożonym i częścią II szwadronu. Przejście do NZW jako 3. Brygada Wileńska odbywało się z perturbacjami spowodowanymi wyczerpaniem walkami i coraz gorszym morale wynikającym z poczucia zagrożenia i zaszczucia przez „utrwalaczy”. Podczas częściowej demobilizacji II szwadronu wybuchł konflikt między "Jastrzębiem” a „Burym”, dotyczący niedostatecznego zabezpieczenia demobilizowanych żołnierzy. „Rekin” usiłował się zastrzelić, słysząc scysję i groźby wobec „Jastrzębia”. W ostatniej chwili „Wiarus” podbił dłoń „Rekina”, uniemożliwiając mu samobójstwo. Wkrótce po kolejnej odprawie „Wiarus”, „Rekin” i „Jastrząb” wyjechali na urlopy. Część swojego urlopu Jurasow spędził u swego przyjaciela O. Christy, służącego w 62. pułku piechoty w Ełku ${ }^{120}$.

Po powrocie z urlopu doświadczeni wileńscy partyzanci szybko uczynili z 3. Brygady NZW zdyscyplinowany oddział. "Wiarus” awansował do stopnia podporucznika i zaczął dowodzić 1. plutonem (gdy „brygada” liczyła ok. 90 żołnierzy). Pierwszą akcją po reorganizacji 3. Brygady NZW było rozbrojenie grupy kontyngentowej i załogi posterunku MO w Sokołach. W przedostatnim dniu $1945 \mathrm{r}$. oddział zaatakował to miejsce, a milicjanci po negocjacjach skapitulowali przed „Wiarusem” i „Rekinem”. W połowie stycznia, gdy powrócił „Bury”, brygada

118 M. Korejwo, op. cit., s. 176-177 oraz G. Motyka, Na białych Polaków obława. Wojska NKWD $w$ walce $z$ polskim podziemiem 1944-1953, Kraków 2014, s. 95-98 i 101.

119 E. Banasikowski, op. cit., s. 348-349 oraz M. Korejwo, op. cit., s. 250, 262.

120 J. Kułak, Rozstrzelany oddział..., s. 125-129; idem, Organizacja i walki III Wileńskiej Brygady NZW (Narodowego Zjednoczenia Wojskowego) kpt. Romualda Rajsa „Burego” (1945 - październik 1946 r.), w: Dzieje polskiego podziemia na Białostocczyźnie w latach 1939-1956. Materiały z sesji naukowej, 24 kwietnia 1992 r. w Instytucie Studiów Politycznych PAN, red. M. Giżejewska, Toruń 1992, s. 80-81. 
zaczęła być ścigana przez grupę operacyjną UB/MO. Dzięki leśnemu doświadczeniu kpt. „Bury” zmylił pościg, który powrócił do Białegostoku. Tymczasem 3. Brygada NZW zaatakowała 28 stycznia 1946 r. Hajnówkę. Pluton „Wiarusa”, wszedł do miasta jako awangarda, ubezpieczając szosę Bielsk-Hajnówka. „Warius” zachował jednak zimną krew, natknąwszy na sowiecką kolumnę transportową. „Niezłomni” udawali szkolenie wojskowe, sugerując Sowietom, że są z ludowego WP. Następnie „Wiarus” opanował posterunek MO i rozbroił milicjantów, rozpoczynając w nim „urzędowanie” od zaaresztowania kilku Sowietów. Coraz intensywniejszy ostrzał od strony linii kolejowej zmusił pluton „Wiarusa” do wycofania się, podobnie jak i inne pododdziały 3 . Brygady NZW. Po nocnym ataku na Hajnówkę doszło do kilku kontrowersyjnych działań z rozkazu „Burego”. Podczas odwrotu przez teren pow. Bielsk Podlaski doszło bowiem do spalenia pięciu wsi, zamieszkałych głównie przez Białorusinów (Zaleszany, Wólka Wyganowska, Zanie, Szpaki i Końcowizna). Pluton „Leszka” (NN), wsparty prawdopodobnie przez pluton „Wiarusa”, stoczył 2 lutego w Szpakach walkę z chroniącą wieś samoobroną, złożoną z byłych partyzantów sowieckich. Wówczas spaliły się 22 zabudowania i zginęło sześciu mężczyzn, a jedna osoba zmarła w wyniku poparzeń. Pluton „Bitnego" walczył w Zaniach z uzbrojoną lokalną samoobroną, co doprowadziło do spalenia $14 \mathrm{z} 22$ domów. W czasie strzelaniny zginęło od 24 do 30 osób (w tym kobiety i dzieci). Wreszcie pluton Jurasowa spalił trzy domy, bez ofiar w ludziach, w Końcowiźnie. Łącznie oddziały PAS Okręgu NZW, podlegające „Buremu”, zabiły między 29 stycznia a 2 lutego 1946 r. prawie 75 osób narodowości białoruskiej. Pacyfikacja pięciu wiosek, akcja na Hajnówkę i rozstrzelanie 30 furmanów w lesie koło wsi Puchały Stare doprowadziły do wysłania sowiecko-polskiej grupy operacyjnej tropem 3. Brygady NZW ${ }^{121}$.

Dowództwo okręgu zdecydowało się przerzucić oddział „Burego” na tereny południowej części Prus Wschodnich, włączonej do Polski. Początkowo nic nie

121 Akcja NZW miała charakter polityczny i była odpowiedzią za sprzyjanie komunistom przez miejscową ludność. To było główną przyczyną pacyfikacji, a nie doraźnie wymyślony konflikt religijno-etniczny między Polakami a Białorusinami lub katolikami i prawosławnymi. Działania podwładnych „Burego” nie są ludobójstwem prawosławnych Białorusinów, kilkadziesiąt-kilkaset ofiar to nie jest forma, skala, przebieg czy skutki ludobójstwa. Ponadto mało osób zauważa, że wyznawcy prawosławia byli żołnierzami i oficerami 3. Brygady NZW (zob.: Kuroczkin i Jurasow), a nigdy nie byli dyskryminowania z powodu swej religii czy pochodzenia. Należy podkreślić, że postanowienie Sądu Warszawskiego Okręgu Wojskowego z 15.09.1995 o uznaniu za nieważne komunistycznych wyroków WSR w Białymstoku z 1.10 .1949 i 3.03.1950 r. jest z prawnego punktu widzenia ważniejsze niż późniejszy raport kończący śledztwo prokuratury z 2005 r., który nie posiada mocy prawnej, zob.: M. Bechta, W.J. Muszyński, op. cit., s. 265-267; S. Iwaniuk, Represje polskiego podziemia wobec ludności białoruskiej na Białostocczyźnie po lipcu 1944 roku, w: Stosunki polsko-białoruskie w województwie białostockim w latach 1939-1956, red. J.J. Milewski, A. Pyżewska, Warszawa 2005, s. 101. Autor wspomina aż o 422 Białorusinach (m.in. 296 cywilach, 66 funkcjonariuszach UB-MO-ORMO oraz 60 członkach PPR, z czego co najmniej 284 to ofiary polskiego podziemia niepodległościowego) oraz J. Kułak, Rozstrzelany oddziat..., s. 231-248. 
zapowiadało fatalnego finału. Nie niepokojona przez komunistów 3. Brygada dotarła do wsi Gajrowskie, gdzie została zlokalizowana przez grupę operacyjną 2. zmot. p. strz. WW NKWD pod dowództwem mjr. Sieruchina, wspieraną przez samochody pancerne. Zaskoczeni „żołnierze niezłomni” podjęli 16 lutego $1946 \mathrm{r}$. nierówną walkę. Partyzanci uszkodzili jeden z sowieckich samochodów pancernych. Dzień później oddział „Burego” zaskoczyła podczas odpoczynku grupa pościgowa NKWD wraz z pododdziałami WP i UB. Doszło do chaotycznej walki w rejonie wsi Gajrowskie (gmina Wydminy, powiat Giżycko). Podwładni „Burego” ponieśli wówczas poważne straty, wynoszące od 14 do 19 zabitych, wśród których byli ppor. Jan Boguszewski „Bitny” oraz por. Włodzimierz Jurasow „Wiarus”. Ponadto Sowieci wzięli do niewoli trzech polskich partyzantów, tracąc dwóch zabitych i sześciu rannych ${ }^{122}$.

Ze wspomnianym wyżej mjr. „Łupaszką” była związana polska partyzantka rosyjskiego pochodzenia, Lidia Lwow. Urodziła się 14 listopada 1920 r. w Plosie (Плёс) w rodzinie inżyniera rolnictwa. Ze strony matki (Barbara z Tiuchanowów) należała do rosyjskiej rodziny szlacheckiej - choć nie była to rodzina książęca ${ }^{123}$.

Moi rodzice byli Rosjanami, a ja jestem Rosjanką. Mój ojciec urodził się w majątku pod Bobrujskiem. Tata ukończył studia rolnicze w Moskwie i był wówczas zafascynowany socjalizmem, a mama botaniką. Rodzice zostawili wszystko i opuścili Rosję w czasie pierwszej wojny światowej. Babcia oczywiście chciała, aby ojciec wyjechał do Polski. W Rosji szalał bolszewizm, działy się straszne rzeczy.

W naszych żyłach płynie też krew polska ze strony ojca. Rodzice spotkali się na froncie, gdzie ojciec służył, chociaż nie był wojskowym. Jako jedyny syn w rodzinie, nie został powołany do armii. Był dostawcą. Bardzo szybko oświadczył [się] mojej matce. Przywiózł ją do nieruchomości Celewicze, gdzie mieszkała jego rodzina - przywołuje przeszłość Lidia Lwow. - Co do babci, mając osiemnaście lat, ukończyła Wileński Instytut dla Szlachetnie Urodzonych Panien, gdzie przypadkowo spotkała mojego dziadka Iwana Lwowa, młodego oficera, trzy lata starszego od niej.

Wkrótce ożenili się i zamieszkali w Petersburgu. Mój dziadek był hazardzistą. Nie pamiętam, ile mieli dzieci, ale przeżyło dwoje: tata młodszy i ciotka starsza o trzy lata. Pradziadek był bardzo zaniepokojony o moją babcię, jedyną córkę, bo jego żona i druga córka umarła, przekonał ją do rozwodu. Tata miał dziesięć lat, gdy moja babcia rozwiodła się z mężem. Pradziadek natychmiast zabrał ją do Włoch, aby zapomniała o mężu. Potem moja babcia spotkała „drugiego wujka”, który był nieco młodszy od niej. Przeżyli razem długo i szczęśliwie, a moja babcia była otoczona opieką i dostatkiem. Razem wychowali ojca ${ }^{124}$.

122 M. Bechta, W.J. Muszyński, op. cit., s. 268-269; K. Krajewski, T. Łabuszewski, „Łupaszka”, „Młot”, „Huzar”. Działalność 5 i 6 Brygady Wileńskiej AK 1944-1952, Warszawa 2002, s. 265266; J. Kułak, Rozstrzelany oddział..., s. 276-310 oraz G. Motyka, op. cit., s. 285-286 (dowódcą sowieckim był kpt. Makarenko).

${ }^{123}$ Русская княжна - партизанка Армии Краёвой, http://www.istpravda.ru/bel/digest/1231/ (dostęp: 17.01.2017).

124 Relacja Lidii Lwow-Eberle, marzec 2015, zbiory własne. 
Kiedy w 1921 r. rodzina Lwowów przyjechała do Polski, ojciec Lidii został nauczycielem w gimnazjum rosyjskim w Nowogródku, a następnie wykładowcą szkoły rolniczej na przedmieściach tego wojewódzkiego miasta. W końcu, ze względu na jego wysokie kwalifikacje, został wyznaczony na agronoma powiatowego. Lidia uczęszczała do gimnazjum państwowego w Nowogródku (i Święcianach?), a następnie szkoły prowadzonej przez siostry nazaretanki, w $1938 \mathrm{r}$. zdała maturę. Wakacje spędzała na Wileńszczyźnie, nad Naroczą, największym ówcześnie polskim jeziorem ${ }^{125}$.

Następnie dostała się na Wydział Prawa Uniwersytetu Stefana Batorego w Wilnie:

Pojechałem na studia z przyjaciółką żydowską. Stąd zapewne przezwisko jakie otrzymałam: „judejka/żydówka”. Na uniwersytecie zetknęłam się ze strasznym stosunkiem do Żydów, że nie mogli siedzieć w ławkach i musieli słuchać wykładów stojąco. Ale na uniwersytecie, jak w gimnazjum, rozmawiałem z Żydówkami i Żydami, a kolega z roku powiedział mi kiedyś: „Jeśli, koleżanka, będzie rozmawiać z Żydami, to przyjdzie nam stosować do ciebie takie same zasady jak do Żydów". Ale jako Rosjanka nie odczuwałam żadnego szykanowania ${ }^{126}$.

Z powodzeniem skończyła pierwszy rok studiów prawniczych i niemal natychmiast zaczęła się wojna. Po ataku wojsk sowieckich na Polskę była w Kobylniku, gdzie pracował jej ojciec (został zesłany za Ural, pracował w lasach i kołchozie, ale przeżył) i mieszkała matka z młodszym bratem, Borysem (który później został wcielony do 2. Armii Polskiej) ${ }^{127}$.

Lidia pracowała jako nauczycielka w szkole wiejskiej we wsi Plietiasza:

Rodzice już nie mieszkali w tym samym mieszkaniu, gdzie dla nich nie było miejsca. Zajęli się pracą w lesie. Leśniczy, Polak, wszystkich młodych zabrał do siebie, dając im jakieś prace. Po wkroczeniu Niemców nie zabrali ich do pracy przymusowej. Mój brat utrzymał pracę leśnictwa, stając się palaczem, a my z mamą też jakoś zostały, dołączyłyśmy do leśnictwa. Mama została kierownikiem małej mleczarni w Kobylniku. W każdym razie mieliśmy mleko, śmietanę - zamiast pieniędzy. Potem pracowałam jako nauczycielka, tym razem w Kupie, małej wiosce niedaleko jez. Narocz ${ }^{128}$.

W interesujący sposób trafiła do oddziału AK „Burza”, jak sama wspomina:

Było to latem 1943 r. Od wczesnej wiosny w rejonie Postawszczyny [?]. Działał pierwszy oddział bojowy Okręgu Wilno AK pod dowództwem dowodzonego przez „Kmicica”

125 AIPN BU, 0 259/436, t. 10, Stenogram z 4, 5, 6 dnia rozprawy p-ko Olechowiczowi Antoniemu i innym, rok 1950, k. 46.

126 Relacja Lidii Lwow-Eberle, marzec 2015, zbiory własne.

127 AIPN BU, 0 259/436/17, t. 2, Akta śledztwa w sprawie o przynależność do AK prowadzonemu przeciwko Antoni Olechnowicz, imię ojca: Ferdynand, ur. 13-06-1905 r. Doniesienie agenta „Gumka”, 25.10.1950, k. 189.

128 Relacja Lidii Lwow-Eberle, marzec 2015, zbiory własne. 
[ppor. Antoniego Burzyńskiego]. On znał mnie osobiście, i któregoś razu powiedział, że mogłabym przydać się w oddziale. Zgodziłam się dołączyć do AK. Pewnego letniego dnia do mojego domu podjechali na bryczce ludzie w mundurach policji białoruskiej [pomocnicza policja Schutzmannschaft] i zabrali mnie ze sobą. Nie zdawałam sobie sprawy, co się stało. Ale jak tylko odjechaliśmy od domu, to od razu przeszli z białoruskiego na polski. Powiedzieli, że mieli przyjechać, żeby mnie do oddziału ${ }^{129}$.

Latem 1943 r. (od połowy sierpnia) Lidia Lwow wstąpiła w szeregi oddziału partyzanckiego AK, działającego na terenie powiatu wilejskiego, dowodził nim ppor. Burzyński. Rosjanka nosiła w konspiracji pseudonimy „Ewa” i „Lala”. W oddziale walczącym z Niemcami pracowała przy kuchni. Według jej oceny, z partyzantami sowieckimi początkowo rozwijały się dobre stosunki, ale polityka sowiecka doprowadziła do krwawej konfrontacji zbrojnej ${ }^{130}$. Oddział „Kmicica” został rozgromiony 26 sierpnia 1943 przez sowiecką Brygadę Partyzancką im. Woroszyłowa płk. Fiodora Markowa ${ }^{131}$.

Lidia Lwow zeznawała po wojnie przed komunistycznym sądem:

Dwa tygodnie potem oddział został rozbrojony przez partyzantów sowieckich, dowódca został zabrany, jak również około 60 chłopców, których tylko część potem wróciła do oddziału z powrotem. Myśmy przeszli pod dowództwo partyzantki sowieckiej i otrzymaliśmy nowego komendanta „Zaporę” [„kapitan”/plutonowy Wincenty Mroczkowski]. [...] Miesiąc później oddział [partyzancki im. Bartosza Głowackiego] w sile około 60 ludzi pod dowództwem "Zapory” wyszedł w teren dla nawiązania łączności z innymi oddziałami, które znajdowały się w terenie. Po nawiązaniu łączności Polacy uciekli do „Łupaszki”. Po negocjacjach weszłam w skład jego oddziału. Było to w końcu września 1943 r. Od tej chwili przyjęłam obowiązki sanitariuszki i w tym oddziale byłam do kwietnia 1947 r. ${ }^{132}$

129 Ibidem oraz Русская княжна...

130 AIPN BU, 0 259/436, t. 1, Wyciąg z raportu Wydz. II. Dep. Śledczego z dn. 15.11.48; Warszawa, 18.11.1948, k. 216; A. Tarnawska, Zamiast broni miałyśmy lekarstwa, „Nowy Dziennik. Polish Daily News”, Garfield, New Jersey, http://www.dziennik.com/wiadomosci/artykul/zamiast-broni-mialysmy-lekarstwa (dostęp: 17.01.2017).

131 Podporucznik ps. „Kmicic” został zamordowany po torturach. Następnego dnia każdy z polskich partyzantów był wzywany na przesłuchanie u naczelnika oddziału specjalnego Brygady Partyzanckiej im. Woroszyłowa. Jego wynikiem było albo ponowne trzymanie pod strażą, albo możliwość swobodnego poruszania się po obozie. Ci, których pilnowali partyzanci (około 80 osób) zostali wyprowadzeni i rozstrzelani w lesie. Tylko trzem partyzantom („Długiemu”, „Szpagatowi” i „Ursusowi”) udało się zbiec. Tymczasem donosiciel z celi więziennej informował o wojennych losach „Ewy”: „Markow wcielił partyzantów polskich w swoje «atriady» razem dostała się i Lwowna, którą Markow (jako stały mieszkaniec Święcian) znał osobiście, a nawet jak podejrzewano, że Lwowna była przedtym jego sympatja [pisownia oryginalna]", zob.: AIPN BU, 0 259/436/17, t. 2, Akta śledztwa w sprawie o przynależność do AK prowadzonemu przeciwko Antoni Olechnowicz, imię ojca: Ferdynand, ur. 13-06-1905 r., Doniesienie agenta „Gumka”, 25 X 1950, k. 189 oraz G. Motyka, op. cit., s. 70-71.

132 AIPN BU, 0 259/436, t. 10, Stenogram z 4, 5, 6 dnia rozprawy p-ko Olechowiczowi Antoniemu i innym, rok 1950, k. 27. 


\section{Kolejne zacięte walki rozgorzały}

[...] w pobliżu Sięcienięty pod Świrem [dopływem Stracza - H.K.] w październiku 1943 r., gdzie przeprowadzała koncentrację V-ta brygada [AK] „Łupaszki” i pluton „Maresa” [V Oddział Partyzancki ppor. Romana Olechnowicza ps. „Mars” (zalążek późniejszej 12. Oszmiańskiej Brygady AK)?], odbyła się potyczka z dziewięcioosobową grupą partyzantów sowieckich, z których trzech zostało zabitych, a reszta uciekając natknęła się na oddział litewski, który wszystkich zlikwidował. W połowie października 1943 r. we wsi Bibki koło Swiru oddziały „Łupaszki” rozbiły pluton żywnościowy partyzantów sowieckich, zabierając przy tym całą żywność. Następnego dnia między wsią Bibki i Pracuły [Pradsuty] oddziały „Łupaszki” zaatakowały z zasadzki grupę żywnościową partyzantów sowieckich, zabierając im ponownie wszystką żywność. Tego samego dnia z zasadzki we wsi Pracuły [Pradsuty] oddziały „Łupaszki” zaatakowały oddział dywersyjny partyzantki sowieckiej. W wyniku walki zabili jednego partyzanta, a kobieta $\mathrm{z}$ tej samej grupy po niemożności wycofania się - popełniała samobójstwo ${ }^{133}$.

W listopadzie doszło do rozmów polsko-sowieckich w Syrowatkach, ale nie przyniosły one żadnych rozwiązań. Jednocześnie doszło do walk z siłami reżimu okupacyjnego - łącznie kilkadziesiąt potyczek z oddziałami litewskimi i niemieckimi, rozbicie pięćdziesięciu policyjnych posterunków i kolejowych stützpunkten i to pomimo osławionych rozmów AK z Niemcami (Abwehrą, a potem Sipo/SD) ${ }^{134}$.

W okresie zimowym walki ustawały, ale zajmowano się doskonaleniem wojskowym, ćwiczeniami z bronią. Kolejne starcia z partyzantką sowiecką miały miejsce w końcu zimy: „2 lutego [1944 r.] po ciężkiej walce z Niemcami odskoczyliśmy, mając 6 ciężko rannych w rejon Sieradziszcze, gdzieśmy zakwaterowali. Następnego dnia zostaliśmy zaatakowani przez przeważające siły partyzantki sowieckiej. Po naszej stronie były również straty"135. W połowie lutego doszło do potyczki pod Jasinem koło Michaliszek - jak zapamiętała go Lidia Lwow, opisując finał tego starcia w końcu lutego: „Wyglądało to w ten sposób, że myśmy się zakwaterowali z całą brygadą we wsi Jasin. W nocy wjechał do wsi patrol sowiecki. Rozpoczęła się walka, która trwała do godz. 10 rano, po czym musieliśmy odstąpić z braku amunicji. [...] Byłam przy oddziale jako sanitariuszka. To ta sama walka, która zaczęła się w Jasinie, a skończyła się pod wsią Żukojny"136.

Bezpośrednio przed operacją „Bagration” doszło do zintensyfikowania starć, o czym wspomniano w jednym z sądowych dialogów: „Potem w maju 1944 r.

133 AIPN BU, 0 259/436, t. 4, Postanowienie o pociągnięciu do odpowiedzialności karnej Lidii Lwow, Warszawa 18.01.1950, k. 68-69.

134 AIPN BU, 0 259/436, t. 1, Wyciąg z raportu Wydz. II. Dep. Śledczego z dn. 15.11.48, Warszawa, 18.11.1948, k. 216; J. Wołkonowski, Okręg Wileński Związku Walki Zbrojnej Armii Krajowej $w$ latach 1939-1945, Warszawa 1996, s. 171-184.

135 AIPN BU, 0 259/436, t. 10, Stenogram z 4, 5, 6 dnia rozprawy p-ko Olechowiczowi Antoniemu i innym, rok 1950, k. 27.

136 AIPN BU, 0 259/436, t. 10, Stenogram z 4, 5, 6 dnia rozprawy p-ko Olechowiczowi Antoniemu i innym, rok 1950, k. 30. 
w tej samej wsi [Siecinięty w rejonie Swiru] był napad na sztab kontrrazwiedki radzieckiej. Co sobie oskarżona przypomina? Ja sobie przypominam tylko akcję w maju 1944 r."137.

Większość starć polsko-litewskich pozostawała bezkrwawa, ale nie potyczka 5. Brygady AK pod Glinciszkami (Glitiškès/ Глитишки), gdzie 19/20 czerwca poległo czterech policjantów litewskich. To wywołało odwet policjantów z 3. kompanii 258-asis lietuviu policijos batalionas (Litauische Polizei-Ers. Bataillon nr 258) dowodzonych przez por. Polekauskasa - Litwini wymordowali w tej miejscowości 39 Polaków, w tym czworo dzieci. Jeszcze straszniejsza była polska odpowiedź - rajd 5. Brygady AK w głąb Litwy Kowieńskiej. Polacy wymordowali do stu Litwinów, głównie policjantów, w tym 23 czerwca zabiły 20-27 mieszkańców Dubinek (Dubingių) oraz sąsiednich wiosek: Janiszki (Joniškis), Inturkie (Inturkè), Bijuciszki (Bijutiškis) i Giedrojcie (Giedraičiai). Później 550 żołnierzy 5. Brygady AK „Łupaszki” przygotowywało się w ramach Zgrupowania 1 do udziału w operacji „Ostra Brama”, której celem było zajęcie Wilna w ramach operacji „Burza” 138 .

Ostatecznie rtm. „Łupaszka” wycofał się na zachód przed atakiem (na co miał ustną zgodę Komendanta Okręgu AK, choć wydaną w innych okolicznościach): „W puszczy Świsłockiej znaleźliśmy się po przejściu z terenu Wilna. [...] Zdaje się lipiec, albo wrzesień 1944 r." ${ }^{39}$. Lidia Lwow przekroczyła niepostrzeżenie linię Curzona u boku mjr. Zygmunta Szendzielarza. Razem przezimowali w Puszczy Białowieskiej. Mobilizacja Brygady nastąpiła w początkach kwietnia 1945 r. w rejonie wsi Oleksin, i wówczas oddział mjr. „Łupaszki” rozpoczął walki z regularnymi oddziałami RKKA i WW NKWD, WP, KBW oraz grupami UB i MO. Szczególną uwagę partyzanci poświęcili zabijaniu agentów UB i członków PPR, uznawanych za zdrajców. Brygada rozbijała posterunki MO i urzędy gminne, urządzała zasadzki. Tylko w kwietniu 1945 r. brygada „Łupaszki” walczyła kilkakrotnie - najpierw w pierwszych dniach kwietnia w pobliżu wsi Kapitańszczyzna uderzyła na obławę oddziału WP i Armii Czerwonej. Dwa tygodnie później w okolicy Siemiatycz rozbroiła pododdział WP strzegący mostu na Bugu (chociaż w czasie wojny mostów na polskim zapleczu frontów białoruskich i w Prusach Wschodnich chroniły

137 Kontrrazwiedka miała być umieszczona przy brygadzie partyzanckiej płk. Monachina [?], zob.: AIPN BU, 0 259/436, t. 10, Stenogram z 4, 5, 6 dnia rozprawy p-ko Olechowiczowi Antoniemu i innym, rok 1950, k. 35 oraz AIPN BU, 0 259/436/17, t. 3, Postanowienie o pociągnięciu do odpowiedzialności karnej [przeciwko Lwow Lidii], 18.01.1950, k. 102.

138 R. Korab-Żebryk, Biała Księga. W obronie Armii Krajowej na Wileńszczyźnie, Lublin 1991, s. 130-139; idem, Operacja Wileńska AK, Warszawa 1988, s. 135; K. Krajewski, Na straconych posterunkach..., s. 404; G. Motyka, op. cit., s. 79; P. Rokicki, Glinciszki i Dubinki. Zbrodnie wojenne na Wileńszczyźnie w połowie 1944 roku i ich konsekwencje we współczesnych relacjach polsko-litewskich, Warszawa 2015 oraz J. Wołkonowski, op. cit., s. 246-247.

139 AIPN BU, 0 259/436, t. 10, Stenogram z 4, 5, 6 dnia rozprawy p-ko Olechowiczowi Antoniemu i innym, rok 1950, k. 37; K. Krajewski, Na straconych posterunkach..., s. 604 oraz G. Motyka, op. cit., s. 93. 
oddziały 14. Dywizji Strzeleckiej Wojsk Wewnętrznych NKWD do ochrony linii kolejowych), zaś pod koniec miesiąca zaatakowali posterunek MO w Narewce, gdzie też rozstrzelali trzech „współpracowników U.B.P.” oraz wychłostali, jak zeznawała Lwow:

młodą kobietę o nieznanym nazwisku, która według danych „Łupaszki” pracowała w N.K.W.D. i była mieszkanką Narewki. Z kobietą przeprowadził „Łupaszko” kilkuminutową rozmowę, po czym wydał polecenie, aby Lejkowski Jerzy ps. „Szpagat” i [NN] ps. „Florek” wykonali na kobiecie tej karę chłosty. [przekreślony tekst] Obaj wymienieni wykonali karę, która polegała na zbiciu kobiety batem skórzanym używanym do jazdy wierzchem na koniu. Po tym na rozkaz „Łupaszki” szwadron „Zygmunta” i „Mścisława” [przekreślony tekst].

\section{Jednocześnie w}

końcu kwietnia 1945 r. „Łupaszka” udał się na kontakt z „Burym” do Hajnówki, natomiast ja ze szwadronem „Mścisława” i przybyłym szwadronem „Zygmunta” przeszliśmy do wsi Łozy w Puszczy Białowieskiej. Następnego dnia rano wymaszerowaliśmy z tej wsi i w jednym z kwartałów puszczy, przy torze kolejki wąskotorowej spotkaliśmy się z „Łupaszką”. Tam polecił on Beynarowi Lechowi ps. „Nowina”, aby z przydzieloną mu drużyną od „Mścisława” udał się do jakiejś wsi i wykonał wyrok śmierci na gospodarzu [donoszącym UB, co ów oficer wykonał do końca miesiąca, meldując się w Rudach] ${ }^{140}$.

Żołnierze „Łupaszki” zrobili zasadzkę na ciężarówkę z 20-osobową grupą aktywistów z ZMW, jadących z Hajnówki do Białowieży. Grupa

zeszła z samochodu i „Łupaszka” rozmawiał z poszczególnymi przykazując, aby nie należeli do Z.W.M. Następnie rozkazał „Łupaszka” rozebrać wszystkich do bielizny, po czym wszyscy zostali bici przez „Juranda”. Spośród bitych wyjątek stanowił brat „Pędzelka” - (imienia nie pamiętam) w związku z którym upozorowano jego ucieczkę i nawet strzelano za nim bezskutecznie. Z tego co wiem nie był on wcale bity, ponieważ poinformował „Łupaszkę” przez „Pędzelka” o tym, że samochód z Z.W.M.-owcami będzie jechał z Hajnówki. Po skończonym biciu polecił „Łupaszka” rozebranym dziewczętom i chłopcom ze Z.W.M. maszerować pod ręce do Hajnówki odległej o 10 km od miejsca zasadzki. Samochód ich z którego zabrano żywność odesłał „Łupaszka” z orkiestrą po pewnym czasie w ślad za grupą Z.W.M. ${ }^{141}$

Tak zakończył się drugowojenny okres służby sanitarnej „Ewy” w oddziale mjr. „Łupaszki”, choć po wojnie w dalszym ciągu wspierała medycznie jego kolejne oddziały:

140 AIPN BU, 0 259/436, t. 10, Stenogram z 4, 5, 6 dnia rozprawy p-ko Olechowiczowi Antoniemu i innym, rok 1950, k. 38; K. Krajewski, Na straconych posterunkach..., s. 742-743 oraz G. Motyka, op. cit., s. 226-231.

${ }^{141}$ Ibidem, k. 38-40. 
Byłam bardzo zakochana w dowódcy. Pewnego dnia wówczas jeszcze porucznik „Łupaszko” zaprosił mnie do swej kwatery i w obecności adiutanta jako świadka powiedział, że od dziś jesteśmy narzeczonymi. Wyjaśnił, że z żoną jest w oficjalnej separacji, że nie ma już żadnych zobowiązań. Ale nie stałam się wtedy panią komendantową. Nie wywyższałam się. Wszystko było jak dawniej. Pozostałam sanitariuszką i nadal mówiłam do „Łupaszki” per komendancie - My nie mieliśmy ślubu cywilnego ani kościelnego ${ }^{142}$.

Po wielu nieudanych próbach zalegalizowania i ustabilizowania życia 30 czerwca 1948 r. UB aresztował mjr. Szendzielarza i Lwow. Rosjanka stanęła 23 października 1950 przed sądem wojskowym, wraz z ppłk. AK Antonim Olechnowiczem, kapitanem AK Henrykiem Borowskim, chorążym AK Lucjanem Minkiewiczem i jego żoną Wandą. Sędzia skazał mężczyzn na śmierć, Wandę Minkiewicz na 12 lat więzienia, a Lidię Lwow - na karę dożywotniego więzienia. Na mocy amnestii została ona zwolniona w 1956 r. Skończyła Instytut Archeologii Uniwersytetu Warszawskiego, wyszła za mąż, przyjmując drugi człon nazwiska - Lidia Lwow-Eberle. Pracowała w Muzeum Warszawy (obecnie Muzeum Historyczne m.st. Warszawy). Kierowała działem archeologicznym Komisji Archeologicznej Obywatelskiego Komitetu Odbudowy Zamku Królewskiego i uczestniczyła w odbudowie Zamku Królewskiego. W 1984 r. przeszła na emeryturę. Po upadku komunizmu w Polsce rozpoczęła aktywną działalność w organizacjach kombatanckich Armii Krajowej. Brała udział w ustalaniu okoliczności śmieci Zygmunta Szendzielarza. Promuje historię AK i 5. Brygady AK, zajmując aktywną postawę antykomunistyczną. Będąc patriotką polską podtrzymuje swoje relacje z Rosją, ostatnio odwiedzała Sankt Petersburg w czerwcu 2015 r. ${ }^{143}$

Emigranci rosyjscy wymienieni w tym artykule są przykładem niekonwencjonalnego postępowania. Większość fascynatów historii twierdzi, że w czasie II wojny światowej „biali” Rosjanie angażowali się po niemieckiej stronie przeciwko bolszewikom. Kwerendy archiwalne, lektury i poznanie żyjących świadków historii pozwoliły przybliżyć mało znane wydarzenia. Artykuł ten to dopiero początek badań losów wielu emigrantów rosyjskich („białych”, antykomunistów) zaangażowanych w walkę z narodowosocjalistycznymi Niemcami - bo przecież należałoby jeszcze wspomnieć Aleksandra Grigorowicza, Konstantego Iwanowa z Obwodu Garwolin AK (zmarłego na zesłaniu w szpitalu w Borowiczach), Jana Szaliłowa ps. „Renek”, Dmitrija Sokolcowa czy Irenę Tamarę Misztal (Tamarę Piotuch)

142 Relacja Lidii Lwow-Eberle, marzec 2015, zbiory własne.

143 AIPN BU, 0 259/436, t. 4, Postanowienie o pociągnięciu do odpowiedzialności karnej [przeciwko Lwow Lidii], 18.01.1950, k. 67; AIPN BU, 0 259/436/17, t. 9, Departament III M.B.P., Wydział 1, nr 3520/B/48, zał. 2 Protokół przesłuchania [...] w charakterze podejrzanego Lwow Lidia ps. „Ewa”, 27.08.1948, k. 35-37; K. Krajewski, Na straconych posterunkach..., s. 803 oraz G. Motyka, op. cit., s. 252-254. 
i innych. Konspirowali i walczyli jakby wbrew tendencjom, wbrew łatwiejszemu życiu, nieraz z jego narażeniem. Ten pasjonujący i nieznany epizod historii drugowojennej wymaga głębszego usystematyzowania i sprawdzenia wielu biografii spośród przedstawicieli przedwojennej porewolucyjnej diaspory rosyjskiej, żyjącej w II RP, a w czasie wojny walczącej „za wolność naszą i waszą”.

\section{Russian emigrants and Polish Underground in 1939-1947}

\section{Abstract}

The article brings up a practically forgotten episode in the history of Russian emigration. The archival search revealed involvement of some post-revolution Russian émigrés in the fight against the Germans during World War II in the territory of occupied Poland. The persons described in this concise article are an example of unconventional behaviour. A year ago the author of the article, when asked on which side Russian emigrants fought in the World War II, answered: on the German side against the Bolsheviks. But discussions with experts and reading of some books changed my opinion; and acquaintance with the eyewitness of history, remembering the described events, is of priceless value.

The article is devoted to the fate of anti-communist Russian émigrés, called Whites, engaged in the fight against the national socialist Germans and Austrians. Those are glorious examples - like forgotten brothers Tumanov (unknown even to the Warsaw Rising Museum), or Jurasov, Kurochkin and Trifonov, fighting in the Polish Home Army of the Navahrudak (Nowogródek) and Vilnius (Wilno). The article has not exhausted the subject, because some other people should be mentioned, such as Alexandr Grigorovich, Jan Shalilov aka Renek, Dmitry Sokolcov or Irena Tamara Mishtal (Tamara Piotuch), and others. They conspired and fought as if against the main stream, against the easy life, or event risking their lives. This unknown, fascinating episode of the World War II history requires that many biographies of the pre-war post-revolutionary Russian émigrés living in the Second Polish Republic (aka "II Rzeczpospolita") and fighting "for our freedom and yours" shall be studied and systematised more thoroughly.

Translated by Grażyna Waluga

\section{Русские эмигранты и польское подполье в 1939-1947 гг.}

\section{Аннотация}

Статья затрагивает почти забытый эпизод истории российской эмиграции. Архивные запросы позволили идентифицировать проблему вовлечения послереволюционных российских эмигрантов в борьбу с немцами во время Второй мировой войны на оккупированных польских территориях. Люди, упомянутые в этой короткой статье, являются примером нешаблонного поведения. Пишущий эти слова, еще год назад на вопрос, на которой стороне находились русские эмигранты во время Второй мировой войны отвечал: на немецкой - против большевиков. Первые известия пришли вместе с беседами со специалистами и предложенными материалами для чтения, а бесценным стало знакомство со свидетелем истории - женщиной, помнящей и видевшей собственными глазами описанные здесь происшествия. 
Эта статья напоминает о судьбах антикоммунистических российских эмигрантов т. н. „белых”, вовлеченных в борьбу против национал-социалистических немцев и австрийцев. Это достойные похвалы примеры, как совсем забыты братья Тумановы (о которых не знал никто, даже Музей Варшавского восстания), или Юрасов, Курочки и Трифонов, сражавшиеся в рядах Новогрудской и Виленской Армии Краевой. Статья не исчерпывает сюжета, так как надо бы упомянуть и Александра Григоровича, Яна Шалилова псевдоним „Ренек”, Дмитрия Сокольцова или Ирену Тамару Мишталь (Тамару Пиотух), а также других. Они вели подпольную деятельность и сражались как будто бы против течения, против более легкой жизни, а даже рискуя ею.

Этот захватывающий и неизвестный эпизод военной истории нуждается в более глубокой систематизации и проверке многих биографий представителей довоенной послереволюционной российской диаспоры, проживавшей во Второй Речи Посполитой и сражавшейся во время войны „за свободу - нашу и вашу”.

Перевод Агнешка Поспишиль

\section{Bibliografia}

\section{Archiwalia:}

Archiwum Akt Nowych

AK, 203/VII-4, 202/II-17, 228/8-2

MSZ, Ambasada RP w Paryżu, t. 82

Mikrofilm aleksandryjski T-311, rol. 213

Archiwum Dokumentacji Historycznej PRL

$\mathrm{N}-\mathrm{I} / 29$

Archiwum Instytutu Pamięci Narodowej

BU 01222/3114; 00168/79, t. 8; 185/340, t. 1; 0-423/2603; 00 1121/4399; 1820/2; 0 259/436,

t. 1 , t. 4 , t. $10 ; 0259 / 436 / 17$, t. 2 , t. 9

GK 919/2656

Archiwum Muzeum Powstania Warszawskiego

$\mathrm{V} / 73, \mathrm{P} / 5187$

Centralne Archiwum Wojskowe

IX.3.26.3

Центральный архив Министерства обороны Российской Федерации

ф. 233 , оп. 2380 , д. 23

Archiwum autora - relacje: Stanisława Aronsona, Józefa Bandzo, Lidii Lwow-Eberle

\section{Źródła drukowane:}

Armia Krajowa $w$ dokumentach 1939-1945, t. 1, cz. 2: Wrzesień 1939 - czerwiec 1941, red.

A. Suchcitz, Waldemar Grabowski [et al.], Warszawa 2015.

Armia Krajowa $w$ dokumentach 1939-1945, t. 3: Kwiecień 1943-Lipiec 1944, Londyn 1976.

Nowogródzki Okręg AK w dokumentach, oprac. K. Krajewski, Warszawa 2009.

Obrona Warszawy w 1939 r. Wybór dokumentów wojskowych, oprac. M. Cieplewicz, Warszawa 1968.

Rozkazy dzienne Brygady Świętokrzyskiej Narodowych Sił Zbrojnych 1944-1945, oprac. C. Brzoza, Kraków 2003. 
Генерал Власов. История предательства, т. 1: Нацистский проект „Aktion Wlassow”, ред. А.Н. Артизов, Москва 2015.

\section{Wspomnienia i pamiętniki:}

Bohun-Dąbrowski A., Byłem dowódca Brygady Świętokrzyskiej NSZ. Pamiętnik dowódcy, świadectwa żolnierzy, dokumenty, Warszawa 1989.

Bonarowski E. „Ostromir”, Burza nad Dworcem Gdańskim. W bój bez broni, Warszawa-Kraków 2014.

Christa O., U „Szczerbca” i „Eupaszki”, Warszawa 2000.

Drucka N., Trzy czwarte... Wspomnienia, Łomianki 2011.

Iwaszkiewiczowa A., Dzienniki i wspomnienia, Warszawa 2000.

Korboński S., W imieniu Rzeczypospolitej, Warszawa 2009.

Korejwo M., Moje ścieżki partyzanckie. W 3. Wileńskiej Brygadzie Armii Krajowej „Szczerbca”, Warszawa-Kraków 2014.

Leski K., Życie niewłaściwie urozmaicone. Wspomnienia oficera wywiadu i kontrwywiadu AK, t. 1, Gdańsk 2009.

Nałkowska Z., Dzienniki, t. 3: 1918-1929, Warszawa 1980.

Skirgieło A., Zapiski ze stuletniego życia, Warszawa 2006.

Wat A., Mój wiek. Pamiętnik mówiony, t. 1, Warszawa 1990.

\section{Materiały:}

Amtliches Fernsprechbuch für den Distrikt Warschau 1942, Warschau 1942.

Drugi Powszechny Spis Ludności z dn. 9 XII 1931 r., Miasto Wilno, „Statystyka Polski”, Seria C, z. 48, Warszawa 1937.

Drugi Powszechny Spis Ludności z dn. 9 XII 1931 r., Województwo Nowogródzkie, „Statystyka Polski”, Seria C, z. 71, Warszawa 1938.

Drugi Powszechny Spis Ludności z dn. 9 XII 1931 r., Województwo Wileńskie bez miasta Wilna, „Statystyka Polski”, Seria C, z. 36, Warszawa 1936.

Konspiracja i opór społeczny w Polsce 1944-1956. Słownik biograficzny, t. 2, red. T. Balbus [et al.], Kraków-Warszawa-Wrocław 2004.

Mały rocznik statystyczny 1939, Warszawa 1938.

Motyl M., Rutkowski S., Rejestr miejsc i faktów zbrodni popetnionych przez okupanta hitlerowskiego. Powstanie Warszawskie 1 VIII - 2 X 1944, Warszawa 1994.

Posłowie i senatorowie Rzeczypospolitej Polskiej 1919-1939. Słownik biograficzny, t. 3: K-Ł, red. P. Majewski, G. Mazur, Warszawa 2005.

Spis abonentów sieci telefonicznej m. st. Warszawy P.A.S.T. i warszawskiej sieci okręg P.P.T.T. Rok 1939/40, Warszawa 1939.

Stanisławski W., „Myśl polityczna emigracji rosyjskiej w II Rzeczpospolitej: interpretacje przeszłości i koncepcje polityczne", praca doktorska napisana pod kier. prof. dr hab. S. Rudnickiego, IH UW, Warszawa 2002, mps P. Dr. 358.

Telefonverzeichnis der stadt Warschau, Warszawa 1940.

Współcześni polscy pisarze i badacze literatury. Słownik bibliograficzny, t. 2, red. J. Czachowska, A. Szałagan, Warszawa 1994.

История отечественной коллаборации. Материалы и исследования, Москва 2017.

От Зарубежья до Москвы. Национально-Трудовой Союз (НТС) в воспоминаниях и документах 1924-2014, ред. В. Сендеров, Москва 2014. 


\section{Opracowania:}

Aronson S., Bukalska P., Rysiek z Kedywu. Niezwykłe losy Stanisława Aronsona, Kraków 2009.

Banasikowski E., Na zew Ziemi Wileńskiej, Warszawa-Paryż 1990.

Bechta M., Muszyński W.J., Przeciwko Pax Sovietica. Narodowe Zjednoczenie Wojskowe i struktury polityczne ruchu narodowego wobec reżimu komunistycznego 1944-1956, Warszawa 2017.

Bohdanowicz J., 3. Brygada Szczerbca Armia Krajowa Okręg Wileński, Warszawa 2008.

Bolecki W., Ptasznik $z$ Wilna. O Józefie Mackiewiczu. Zarys monograficzny, Kraków 2013.

Boradyn Z., Niemen rzeka niezgody. Polsko-sowiecka wojna partyzancka na Nowogródczyźnie 1943-1944, Warszawa 2013.

Cabanowski M., Generał Stanisław Bułak-Bałachowicz. Ostatni Kmicic II RP i wyklęci żołnierze wojny polsko-sowieckiej 1920 r., Warszawa-Kraków 2013.

Die polnische Heimatarmee. Geschichte und Mythos der Armia Krajowa seit dem Zweiten Weltkrieg, red. B. Chiari, J. Kochanowski, München 2003.

Drucka N., Szkoła w podziemiu. Z dziejów polskiego tajnego nauczania w latach okupacji hitlerowskiej, Warszawa 1973.

Grabowski W., Polska Tajna Administracja Cywilna 1940-1945, Warszawa 2003.

Jastrzębski A., Życie na krawędzi, w: Życie na krawędzi. Wspomnienia żołnierzy antyhitlerowskiego wywiadu, oprac. W. Kozaczuk, Warszawa 1980.

Juzwenko A., Polska a „biała” Rosja (od listopada 1918 do kwietnia 1920 r.), Wrocław 1973.

Komorowski K., Polityka i walka. Konspiracja zbrojna ruchu narodowego 1939-1945, Warszawa 2000.

Korab-Żebryk R., Biała Ksiega - W obronie Armii Krajowej na Wileńszczyźnie, Lublin 1991.

Korab-Żebryk R., Operacja Wileńska AK, Warszawa 1988.

Krajewski K., Łabuszewski T., „Łupaszka”, „Młot”, „Huzar”. Działalność 5 i 6 Brygady Wileńskiej AK 1944-1952, Warszawa 2002.

Krajewski K., Łabuszewski T., Białostocki Okręg AK-AKO. VII 1944 - VIII 1945, Warszawa 1997.

Krajewski K., Na straconych posterunkach. Armia Krajowa na Kresach Wschodnich II Rzeczypospolitej 1939-1945, Kraków 2015.

Krajewski K., Uderzeniowe Bataliony Kadrowe 1942-1944, Warszawa 1993.

Kułak J., Rozstrzelany oddział. Monografia 3 Wileńskiej Brygady NZW Białostocczyzna 19451946, Białystok 2007.

Literatura rosyjska na emigracji. Współcześni pisarze rosyjscy w Polsce. Frazeologia i frazeografia. Materiały konferencji naukowej (9-10 listopada 1995 r.), red. W. Skrunda, W. Zmarzer, Warszawa 1996.

Mitzner P., Warszawski, krag Dymitra Fiłosofowa, Warszawa 2015.

Motyka G., Na białych Polaków obława. Wojska NKWD w walce z polskim podziemiem 19441953, Kraków 2014.

Muszyński W.J., Duch młodych. Organizacja Polska i Obóz Narodowo-Radykalny w latach 1934-1944. Od studenckiej rewolty do konspiracji niepodległościowej, Warszawa 2011.

Niwiński P., Okręg Wileński AK w latach 1944-1948, Warszawa-Kraków 2014.

Piekarski M., Samotna placówka, Warszawa 1989.

Rostkowski J., Świat Muszkieterów. Zapomnij albo zgiń, Poznań 2016.

Skirgiełło A., Powstanie i rozwój Zakładu Systematyki i Geografii Roślin Uniwersytetu Warszawskiego ( $w$ zarysie), Warszawa 2001.

Spałek R., Komuniści przeciwko komunistom. Poszukiwanie wroga wewnętrznego w kierownictwie partii komunistycznej w Polsce w latach 1948-1956, Poznań-Warszawa 2014. 
Thomas N., Caballero C., Germany's Eastern Front Allies (2): Baltic Forces, Oxford 2012.

Tomaszewski L., Wileńszczyzna lat wojny i okupacji 1939-1945, Warszawa 2010.

Urbanek B., Pielegniarki i sanitariuszki w Powstaniu Warszawskim w 1944 r., Warszawa 1988.

Warszawa we wrześniu 1939 r. Obrona i życie codzienne, red. C. Grzelak, Warszawa 2004.

Wieczorkiewicz P.P., Historia polityczna Polski 1935-1945, Poznań 2014.

Wołkonowski J., Okręg Wileński Związku Walki Zbrojnej Armii Krajowej w latach 1939-1945, Warszawa 1996.

Wroniszewski J.K., Ochota - Okęcie. Przewodnik historyczny po miejscach walk i pamięci z lat 1939-1944, Warszawa 2002 (seria: Warszawskie Termopile 1944).

Zimmerman J.D., The Polish Underground and the Jews, 1939-1945, Cambridge - New York 2015.

Булгаков В., Словарь русских зарубежных писателей, New York 1993.

Грибков И., Ковтун И., Жуков Д., Особый штаб „Россия”, Москва 2011.

Жуков Д., Ковтун И., 29-я гренадерская дивизия СС „Каминский”, Москва 2009.

Зарубежная Россия 1917-1939 г2.: Сборник статей, ред. В.Ю. Черняев, Санкт-Петербург 2000.

Лавринец П., К истории Виленского содружества поэтов, „Literatura” (2002), nr 44.

Окулов А., В борьбе за Белую Россию. Холодная гражданская война, Москва 2013.

Русская эмиграция в борьбе с большевизмом, ред. С.В. Волков, Москва 2005.

\section{Prasa:}

Acta Societatis Botanicorum Poloniae

Biuletyn Instytutu Pamięci Narodowej

Dzieje Najnowsze

Echa Polesia

Glaukopis

Journal of Slavic Military Studies

Rocznik Historii Czasopiśmiennictwa Polskiego

Rocznik Mazowiecki

Rocznik Warszawski

Studia Religiologica

Zagłada Żydów. Studia i Materiały

Ежегодник Дома русского зарубежья

Новая Польша

Новый журнал

\section{Internet:}

http://www.cmentarzekomunalne.com.pl

http://www.dziennik.com/

http://forum.vgd.ru

http://www.gazetawilanowska.pl

http://www.istpravda.ru

https://www.forces-war-records.co.uk

http://www.1944.pl 
Hubert Kuberski, mgr, absolwent Wydziału Historycznego Uniwersytetu Warszawskiego; historyk, dziennikarz i filmowiec. Zainteresowania badawcze: Bałkany, II wojna światowa, „Bandenbekaempfung". Autor: Sojusznicy Hitlera 1941-45. Armie sojusznicze Niemiec na froncie wschodnim i na Bałkanach, Warszawa 1993; Wschodnioeuropejscy ochotnicy cudzoziemscy w niemieckich oddziałach Ostheer, SS i policji, pacyfikujących Powstanie Warszawskie. Casus „własowców”, Kałmuków i SS Galizien, „Dzieje Najnowsze” (2015), nr 3 (h.kuberski@gmail.com).

Hubert Kuberski, MA, a graduate of the History Institute of the University of Warsaw; historian, journalist, and filmmaker; his interests focus on: the Balkans, World War II, "Bandenbekaempfung". The author publications, including: Sojusznicy Hitlera 1941-45. Armie sojusznicze Niemiec na froncie wschodnim i na Bałkanach (Warsaw, 1993); "Wschodnioeuropejscy ochotnicy cudzoziemscy w niemieckich oddziałach Ostheer, SS i policji, pacyfikujących Powstanie Warszawskie. Casus 'własowców', Kałmuków i SS Galizien”, Dzieje Najnowsze (2015, no. 3) (h.kuberski@gmail.com). 